\title{
8. MIOCENE FORAMINIFERAL STRATIGRAPHY, DSDP SITE 397 (CAPE BOJADOR, NORTH ATLANTIC)
}

\author{
Gianfranco Salvatorini, Institute of Geology and Paleontology, University of Pisa, Italy \\ and \\ Maria Bianca Cita, Department of Geology and Paleontology, University of Milano, Italy
}

\begin{abstract}
Biostratigraphic investigations have been conducted on planktonic foraminiferal assemblages from a 627 -meter thick interval encompassing Cores 33 to 97 of Hole 397. The upper part of the section consists of hemipelagic sediments yielding rich and well-diversified faunas. From Section 397-57-3 to Core 397-61, slumps are frequent and disturb the biostratigraphic record. Evidence of dissolution at depth is recorded, especially in the upper Miocene. Turbidites and debris flows are also present; the latter representing the dominant transport mechanism for sediments from Core 397-78 downwards, and the fossil assemblages are often sparse and/or poorly preserved.

All the biozones known from the time interval encompassing the Burdigalian, Langhian, Serravallian, Tortonian, Messinian, and Zanclean stages have been recognized. Zone N.16 is here emended, and two new biozones are defined: Sphaeroidinellopsis seminulina paenedehiscens Partial-Range-Zone and Globigerina nepenthes Interval-Zone.

A strongly condensed sequence, with at least two biostratigraphically identifiable hiatuses, is recorded in the interval from Cores 397-71 to 77, which is middle Miocene (Serravallian).

The Tortonian/Messinian and Messinian/Zanclean boundaries could be identified with accuracy in the hemipelagic sequence postdating the slump interval, and these boundaries are correlated with stratotype sections in the Mediterranean area. The duration of the "salinity crisis" could also be precisely defined: it falls entirely within paleomagnetic Epoch 5.

Several evolutionary lineages could be followed, and are documented with SEM photographs. New observations on the evolutionary trends recorded in representatives of the genus Sphaeroidinellopsis are provided.

The Miocene succession continuously cored at DSDP Site 397 is the thickest and the most complete recovered so far from the eastern North Atlantic. Despite its upper continental rise setting and the occurrence of sediment types such as debris flows (in the lower) Miocene) and volcaniclastic sandstones (in the middle Miocene), the biostratigraphic succession is relatively little disturbed and no major gaps are recorded within the Neogene. Consequently, we can consider the Cape Bojador section as a reference section for the North Atlantic, especially with regard to upper Neogene sediments.
\end{abstract}

\section{INTRODUCTION}

The present paper reports the results of biostratigraphic research carried out on the Miocene succession continuously cored at DSDP Site 397 , located on the upper continental rise off Cape Bojador (eastern North Atlantic, lat $26^{\circ} 50.7^{\prime} \mathrm{N}$, long. $15^{\circ} 10.8^{\prime} \mathrm{W}$ ). The samples investigated total 231 , beginning with Core 397 33 , which is early Pliocene in age and postdates the
FAD $^{1}$ of Globorotalia puncticulata (M P1 2/M P1 3 zonal boundary of Cita, 1975b), to Core 397-97, which is early Miocene in age (Zone N.7 of Blow, 1969). Cores 98 to 102 at Hole 397 had little or no recovery. The early Miocene succession penetrated at Hole 397A, extending for some 313 meters below the level corre-

\footnotetext{
${ }^{1} \mathrm{FAD}=$ First appearance datum.
} 
lated with Core 397-102, is not discussed here in detail, but is considered in the part of this contribution devoted to correlations.

Though the purpose of the present paper is primarily to elucidate the Miocene biostratigraphy of planktonic foraminifers, we extend our observations several dozens of meters into the Pliocene, in order to establish precise biostratigraphic reference points for the correlation of the Miocene/Pliocene boundary, and to correlate accurately the latest Miocene (Messinian) stage. This time interval is characterized in the Mediterranean by a basin-wide "salinity crisis" (Ruggieri, 1967; Ryan, et al., 1974; Cita, 1972). We were curious to study a correlative biostratigraphic interval of the Messinian in an eastern North Atlantic setting at about the same latitude as the Mediterranean, and to utilize new observational data to check the duration of the salinity crisis as previously put forward by Ryan et al. (1974).

\section{FACTORS WHICH DISTURB THE BIOSTRATIGRAPHIC SUCCESSION}

Several factors, mainly sedimentary processes and the evolution of water masses in the eastern North Atlantic, affect the distribution of planktonic foraminiferal assemblages. They result in "noise" superimposed over the normal evolution of foraminiferal assemblages, as a function of time (biostratigraphic signal). Disturbing factors include (a) slumping, (b) reworking from older formations, (c) downslope displacement, (d) dissolution at depth, (e) preservation, and (f) submarine erosion.

The most effective of these factors in this section are (a) and (f). Slumping is recorded, especially in the interval from Sections 397-57-3 to 397-61-5; lower in the section (as far as Core 397-72), slumps are occasionally recorded. Biostratigraphic evidence of submarine erosion was found between Cores 397-70 and 71. Core 71 yields foraminiferal faunas of Zone N.14 age (based on the recorded co-occurrence of Globigerina nepenthes and of Globorotalia siakensis). Core 70 yields Globorotalia acostaensis, the zonal marker of Zone 16 . There is no evidence of Zone N.15 which, therefore, signifies a hiatus.

Another hiatus can be inferred between Cores $397-$ 77 and 78. At the top of Core 78, several taxa disappear simultaneously, including Praeorbulina spp., Globigerinoides sicanus, Globorotalia praescitula, G. praemenardii arachaeomenardii, and Cassigerinella chipolensis, whereas several species first occur in the lower part of Core 77: Orbulina universa, Globorotalia peripheroacuta, G. praemenardii praemenardii, and Globigerinopsis aguasayensis. The reader is referred to the Site Chapter (this volume) for details on the other disturbing factors.

\section{COMMENTS ON SOME LINEAGES OF PLANKTONIC FORAMINIFERS}

Several evolutionary lineages of planktonic foraminifers are known from the interval under discussion. Some could be followed step-by-step in the succession penetrated at Site 397. In the lower part of the section, where the majority of the sediments are allochthonous, we looked for intervals most likely to yield undisturbed fossil assemblages for dating purposes.

Figures 1 through 5 show SEM photographs illustrating relationships between various steps of five discrete evolutionary lineages, and the ranges recorded in the cores investigated. A few comments follow.

Praeorbulina-Orbulina lineage (Figure 1). This wellknown lineage, which originates from Globigerinoides sicanus, has been thoroughly documented by Blow (1956). Sparse, small-sized specimens are recorded down to the core catcher of Core 397-97. We consider these lowermost occurrences dubious ( $G$. cf. sicanus of the range chart), and prefer to locate the FAD G. sicanus in Sample 397-8, CC, where the first really typical and fully developed specimens appear. The FAD of $G$. sicanus is used by Blow (1969) to identify the Zone N.7/ N. 8 boundary, however other authors, including Brönnimann and Resig (1971) and Stainforth et al. (1975), record the taxon as low in Zones N.6 and N.7, respectively.

The second step of the lineage is represented by the FAD of Praeorbulina, which occurs in the lower part of Zone N.8 and characterizes the base of the Langhian stage of the middle Miocene. In agreement with other data available in the current literature, the first two species of this genus are $P$. transitoria and $P$. glomerosa curva. Their joint occurrence in Core 397-89 might be artificial, since this core had a poor recovery. $P$. glomerosa glomerosa is first recorded in Sample 397 84, CC, and P. glomerosa circularis in Section 397-792 . The first evolutionary appearances of these two subspecies occur with Zone N.8 and within the Langhian stage/age.

The third step is represented by the FAD of Orbulina suturalis, evolving from $P$. glomerosa circularis, which event marks the N.8/N.9 boundary. This FAD is recorded in Section 397-78-2, along with the FAD of $O$. bilobata (evolving from $P$. transitoria).

The fourth and final step is represented by the FAD of Orbulina universa. which occurs slightly above the FAD of $O$. suturalis. Although this biostratigraphic event is recorded at the base of Core 397-77, it cannot be considered as a first evolutionary appearance because it follows a biostratigraphic gap corresponding to most of Zone N.9 and to Zone N.10, or part of it.

Globorotalia peripheroronda-G. fohsi lineage (Figure 2 ). This lineage, which is well known (Bolli, 1950, 1957; Blow and Banner, 1966; Olsson, 1972), represents a basic tool in biostratigraphy and correlation of middle Miocene successions from tropical areas. Any discrepancies essentially involve the taxonomical nomenclature applied to the consecutive steps of this evolutionary sequence (see Jenkins, 1966; Bolli, 1967; Cifelli, 1968; Blow, 1969; Beckmann et al., 1969; Olsson, 1972; Stainforth et al., 1975). In the present paper, we follow Blow and Banner (1966).

The first step of the lineage is represented by $G$. peripheroronda, which is recorded from the lowermost sample investigated. Indeed, we recorded this taxon as 


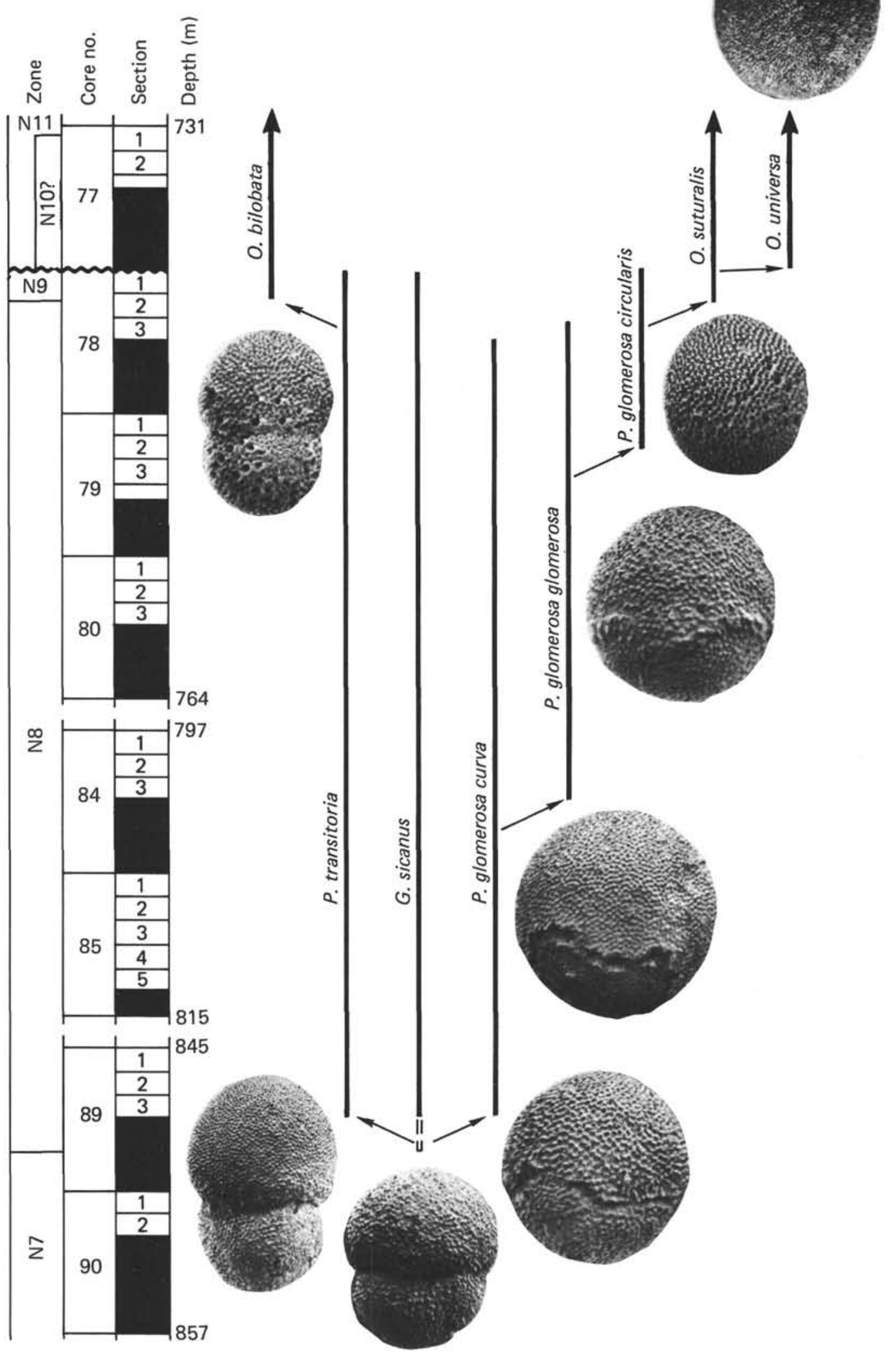

Figure 1. Praeorbulina-Orbulina lineage as recorded at DSDP Site 397. 


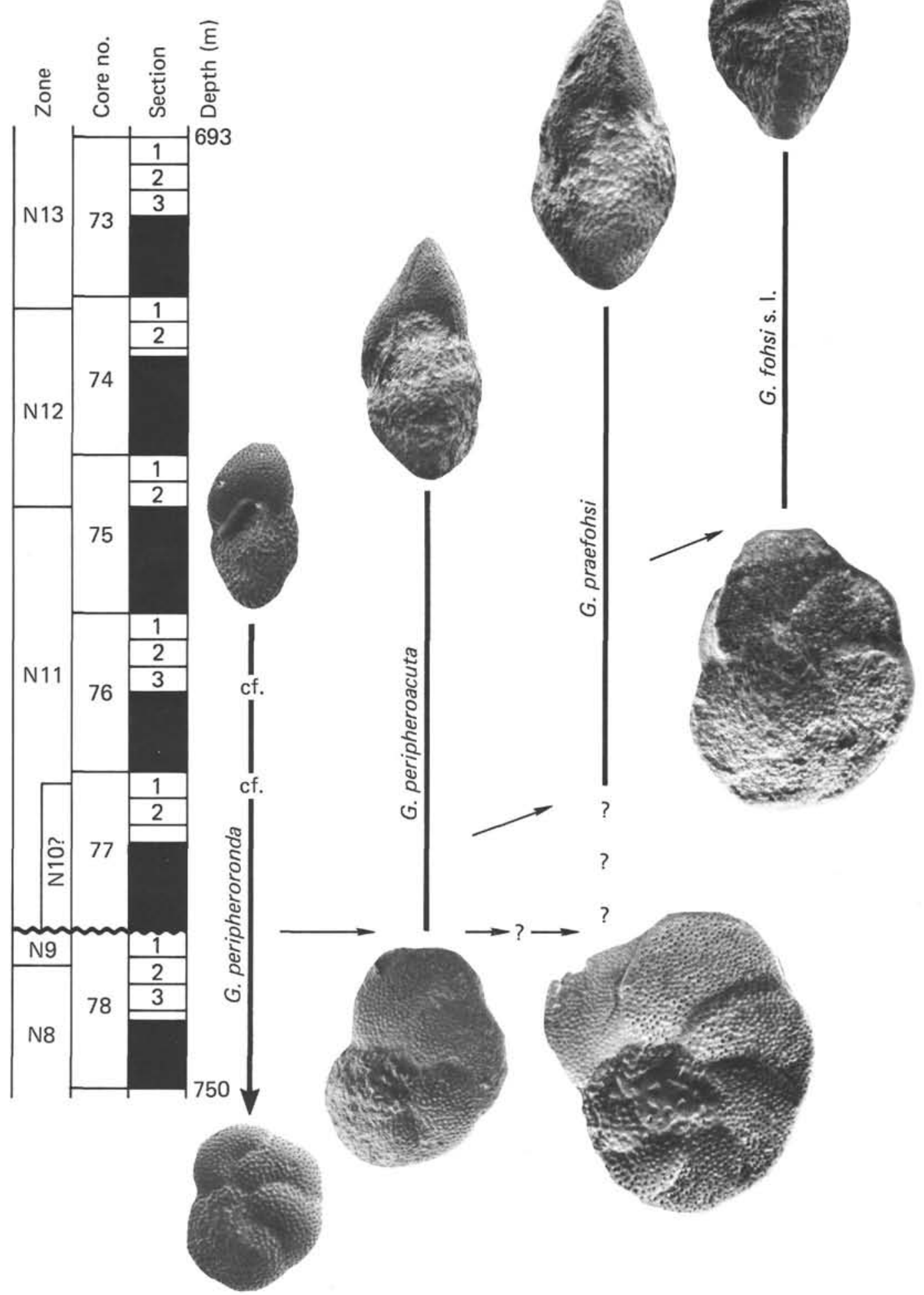

Figure 2. Globorotalia peripheroronda-G. fohsi s.l. lineage as recorded at DSDP Site 397. 
low as Core $397 \mathrm{~A}-12$, which means approximately 100 meters lower in the stratigraphic column. In Section 397-78-1, within the population of $G$. peripheroronda, specimens were found which display more compressed (though not yet acute) chambers in their peripheral part; this is an evolutionary trend towards $G$. peripheroacuta, the second step of the lineage. The latter taxon occurs starting from Sample 397-77, CC in its typical form. A minor hiatus between the two samples interrupts the trend.

The third clear step we can recognize is represented by $G$. praefohsi, first recorded in Section 397-77-1. In the interval immediately underlying this section, this group of forms is extremely rare; also, the poor preservation prevents detailed observations. Consequently, we cannot exclude that the FAD of praefohsi could actually occur earlier (see Biochronology). Starting from Core 397-77 upwards, G. peripheroronda decreases in abundance and progressively loses its diagnostic characteristics ( $G$. cf. peripheroronda of the range chart), disappearing at the top of Core 397-76.

The fourth step is represented by $G$. fohsi s. str., whose FAD is in Sample 397-75, CC. After an interval devoid of Globorotalias referable to this plexus, which encompasses part of Cores 397-74 and 75, G. fohsis. str. reappears, along with $G$. fohsi forma lobata (from Section 397-74-1) and $G$. fohsi forma robusta (from Section 397-73-2). The (minor) discrepancies recorded in the relative distribution of these taxa in the Cape Bojador succession and in Blow's generalized zonal scheme might be accounted for partly by the interval being one of sediments unfavorable to planktonic foraminifers and partly by incomplete core recovery.

Globorotalia fohsi s.l. becomes extinct after Core 397-73-1. Higher occurrences of one or other taxon of this lineage are accounted for either by reworking, or by slumping.

Globorotalia praescitula-G. cultrata s.1. lineage (Figure 3 ). The first step of the lineage $G$. praescitula is recorded through Cores 397-78 to 97.

The FAD of the second step, represented by $G$. praemenardii archaeomenardii occurs in Sample 397 $81, \mathrm{CC}$, which we referred to Zone N. 8. According to our observations on the specimens from Site 397, the evolution of fully keeled, younger forms from nonkeeled, older forms occurs exactly as described by Blow $(1959,1969)$. In Core 397-84 we observed specimens ex interc "praescitula"'-"archeomendardii" (G. cf. praemenardii of the range chart) with a faint peripheral keel in the last or occasionally in the penultimate chamber; they have a larger, more compressed test than $G$. praescitula.

The evolution leading from $G$. praemenardii archeomenardii to $G$. praemenardii praemenardii (the third step) cannot be followed because of the already-mentioned hiatus below Core 397-77. According to Blow (1969), the evolutionary passage should occur in the latest part of Zone N.9, whereas G. praemenardii s.s. first occurs in Core 397-77, which we refer to Zone N.11 (or latest part of N.10).
The fourth step of this lineage is represented by $G$. cultrata s.1. (including G. cultrata cultrata, $G$. cultrata menardii, and $G$. cultrata limbara). This taxon is recorded with typical specimens starting from Core 397 73 upwards.

The evolution from $G$. praemenardii praemenardii to $G$. cultrata s.l. involves the following trends: increase in the size of the test and the umbilicus; the peripheral keel becomes stronger, and both the intercameral and the spiral sutures become limbated; the chambers of the last-formed whorl increase in number; and tests tend to become flatter and to display a subcircular, instead than a somewhat elongated, equatorial periphery. Reference is made to Cita et al. (1978) where the taxonomy of the transitional forms was discussed and documented by SEM micrographs, while describing the Miocene succession at DSDP Site 372 in the western Mediterranean. In the present paper, G. ex cultrata group of Cita et al. (that is to say with a sutural limbation extended to the whorls preceding the last one, but with a general morphology still resembling praemenardii; see Plate 13, Figures 15-21) has been included in the concept of $G$. praemenardii praemenardii. As a consequence, the latter taxon has a wider stratigraphic distribution than indicated by Blow (1969); indeed, it is recorded at Site 397 as high as in Zone N.14.

The later steps of the $G$. menardii lineage, with the development of $G$. miocenica, $G$. exilis, and related taxa, are recorded in the Pliocene succession of Site 397 but are not discussed here.

Globigerina druryi-G. nepenthes lineage. Both taxa are here considered in a broad sense: $G$. druryi (see Plate 1, Figures 9, 13, and 14) includes G. pseudodruryi and $G$. nepenthoides, both described by Bronnimann and Resig (1971). G. nepenthes (Plate 1, Figure 19; Plate 2, Figures 1 and 2) includes G. picassiana Perconig and $G$. nepenthes delicatula Brönnimann and Resig. The creation of all these taxa seems to us weakly justified, taking into account the remarkable variability of the plexus. The ancestral species $G$. druryi, as here intended, is recorded from the base of the section investigated (Zone N.7). This range is stratigraphically lower than that recorded by Blow (1969), but is consistent with the findings from the equatorial Pacific reported from DSDP Leg 7 (Brönnimann and Resig, 1971), with reference to G. pseudodruryi and $G$. nepenthoides, which we lump together with $G$. druryi.

The development of $G$. nepenthes is quite gradational: transitional forms are recorded through a long range encompassing Zone N.11 to N.13 (see also Cita et al., 1978). The FAD of $G$. nepenthes is used to identify the N.13/N.14 zonal boundary and is calibrated to the paleomagnetic stratigraphy (Ryan et al., 1974); we, therefore, paid special attention to locate it precisely. As recorded in Section 397-72-2, it corresponds to the first common occurrence of typical, well-developed specimens.

Globorotalia continuosa-G. humerosa humerosa lineage (Figure 4). Globorotalia continuosa, which represents the first step of this evolutionary sequence, is re- 


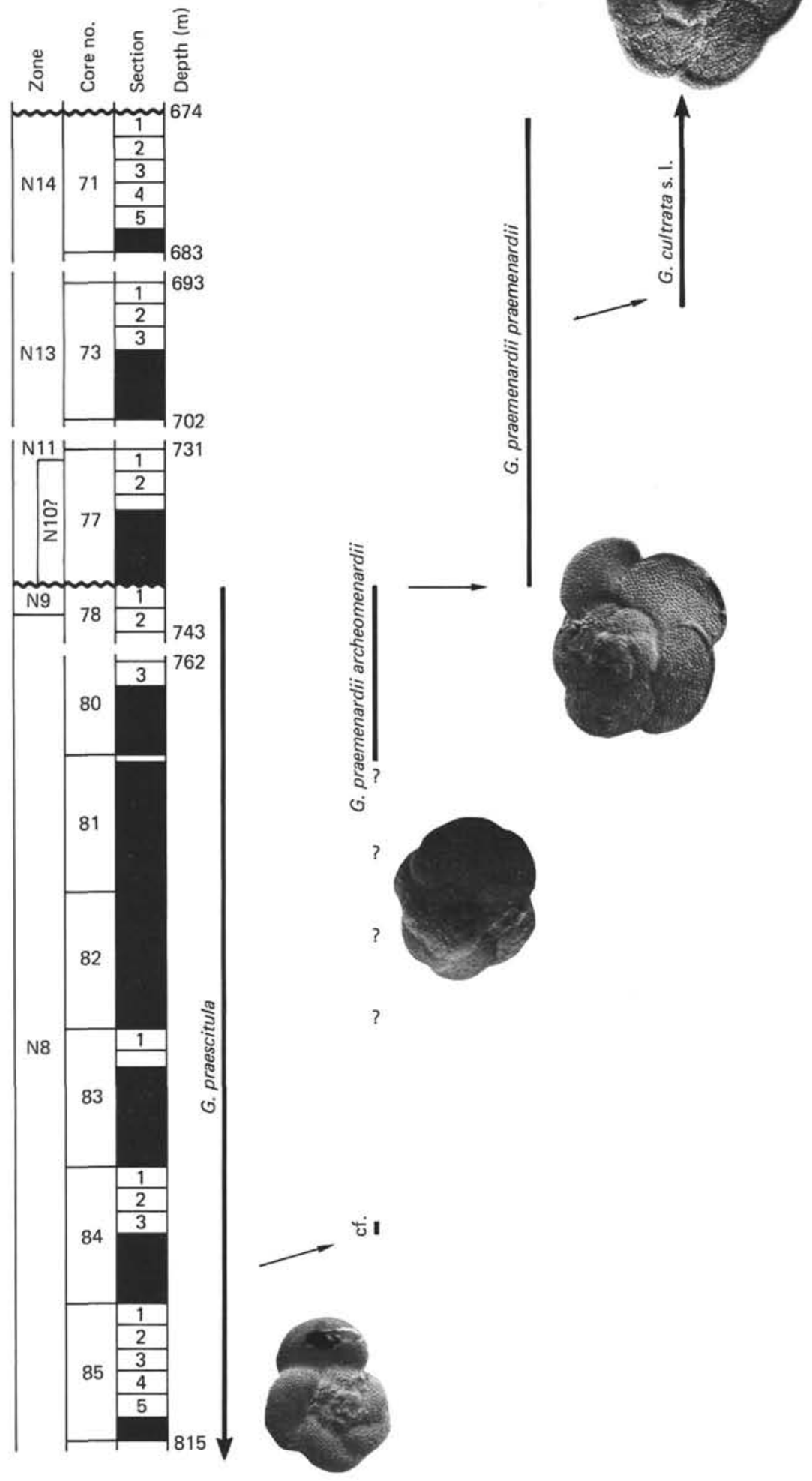

Figure 3. Globorotalia praescitula-G. cultrata s.l. lineage as recorded at DSDP Site 397. 
corded in its typical form only from Section 397-76-3 (Zone N.11). This long-ranging species co-occurs with G. acostaensis from Cores 397-57 to 70 (Zone N.16). At Site 397, however, it is impossible to locate the $\mathrm{LAD}^{2}$ of $G$. continuosa, because of the slumpings and reworking recorded from Section 397-57-3 to Core 397-61.

The FAD of $G$. acostaensis, the second step of this lineage and zonal boundary N.15/N.16, is recorded in Core 397-70 after a hiatus comprising Zone N.15 and probably part of Zone N.14. As a consequence, we have no record of the transition from $G$. continuosa to $G$. acostaensis. According to the most qualified literature, the third step in the evolution is represented by $G$. humerosa s.1., however, discrepancies exist between the various authors in pinpointing the first evolutionary appearance of this taxon (compare, for instance, the ranges and/or comments given by Blow, 1969; Bizon and Bizon, 1972; Bolli, 1970; Cita and Blow, 1969; Parker, 1967, 1973; Brönnimann and Resig, 1971; Catalano and Sprovieri, 1971; Ryan et al., 1974; Saito et al., 1975; d'Onofrio et al., 1975; Natori, 1976; Srinivasan and Kennett, 1976; etc). According to our observations on the faunal assemblages recorded at DSDP Site 397, the transition from $G$. acostaensis to $G$. humerosa s.l. is quite gradational. The morphological changes include (a) increasing number of chambers in the final whorl, from five in acostaensis to six or more in humerosa s.l.; (b) increasing size of the umbilical cavity small in acostaensis and large in humerosa: and (c) general size of the test much larger in humerosa s.l. (see Figure 4 ). We have recorded typical populations of $G$. humerosa humerosa, starting from Core $397-40$, which is early Pliocene in age. However, starting from Section 397-63-1 (Zone N.16), or from levels predating the FAD of Globigerinoides obliquus extremus, we recorded rare specimens with five or six chambers in the last-formed whorl and with a fairly wide umbilical area; these forms display intermediate morphological features between $G$. acostaensis and $G$. humerosa s. s. We referred these forms to G. humerosa praehumerosa, following Natori (1976). The diagnosis of this species corresponds to that of the forms previously identified by the present authors as $G$. humerosa from the upper Miocene.

Globorotalia margaritae lineage. The evolution of $G$. margaritae (Plate 10, Figures 20 and 21) from a nonkeeled form strictly related to $G$. scitula can be followed step-by-step within the upper Miocene from Cores 397 44 to 50 , the FAD of $G$. margaritae being located in Section 397-45-1. At this level, we find forms typical in all regards, i.e., with reference to external morphology, wall structure, and dimensions in comparison with topotypes kindly made available by $\mathrm{H}$. M. Bolli and P.

\footnotetext{
${ }^{2} \mathrm{LAD}=$ Last appearance datum.
}

Bermudez. In the interval encompassing Cores 397-44 to 50, we recorded a complex stock of Globorotalias including several morphotypes rapidly evolving towards the typical G. margaritae. In this evolution, the carinal structure is acquired palingenetically, repeatedly, and heterochronously. Within the rich populations of $G$. margaritae s.l., we recognized an evolutionary trend in agreement with that described by Cita (1972) in the Mediterranean deep-sea record, also recognized by Bolli and Premoli Silva (1973) in the Caribbean (DSDP Leg 15). The three subspecies G. margaritae margaritae, G. margaritae primitiva, and $G$. margaritae evoluta have been identified at Site 397; however, in the range chart, we did not plot them separately. References to the $G$. margaritae lineage are found in numerous papers (including Blow, 1969; Berggren and Amdurer, 1973; Berggren and Haq, 1976; Stainforth et al., 1975; Parker, 1967, 1973; Cita, 1972, 1975b; Zocchi, 1974; Colalongo and Sartoni, 1967; Wernli, 1977; Catalano and Sprovieri, 1971; and Bossio et al., 1976), but we consider the problem still open, and plan to study it in the near future.

Sphaeroidinellopsis lineage (Figure 5). The genus Sphaeroidinellopsis is ubiquitous in the Cape Bojador section, ranging from Cores $397-33$ to 97 . This circumstance allowed us to follow its evolutionary trends through most of the Miocene and the early Pliocene. The evolution of this plexus has been investigated by Blow (1969), who delineated a lineage starting from $S$. seminulina seminulina (Zone N.6 to N.21) and leading to $S$. subdehiscens paenedehiscens (N.17 to N.20), via $S$. subdehiscens susbdehiscens (N.13-N.19?). The distinctive criteria, the terminology, and the distribution of individual taxa was given by Blow (1956) only partially agree with our observations on the Site 397 populations. According to us, the importance of the number of chambers in the last-formed whorl has been overemphasized as a taxonomic character in the past: much more meaningful features which display distinctive evolutionary trends are (a) structure of the cortex and (b) characters of the umbilical margin. In every step of the lineage, forms with three or four or more chambers are consistently associated. Transitional forms are present throughout, which cannot be distinguished on the basis of features unrelated to the architecture deriving from the number of chambers, i. e., general shape of the test, peripheral lobation, and width of the umbilicus. We consider the forms with more than three chambers in the last-formed whorl of marginal value since the terminal chamber is often aberrant. According to these criteria, the evolution of the group is delineated as follows.

The first step is represented by $S$. disjuncta which is recorded from Core 397-97 upwards. This form displays a very coarse external cortex (neither smooth nor hyaline), a globular test, and subspherical chambers separated by deeply incised sutures. The umbilicus in the three-chambered specimens is narrow, the "aperture" consists of a low slit and is umbilical-extraumbil- 

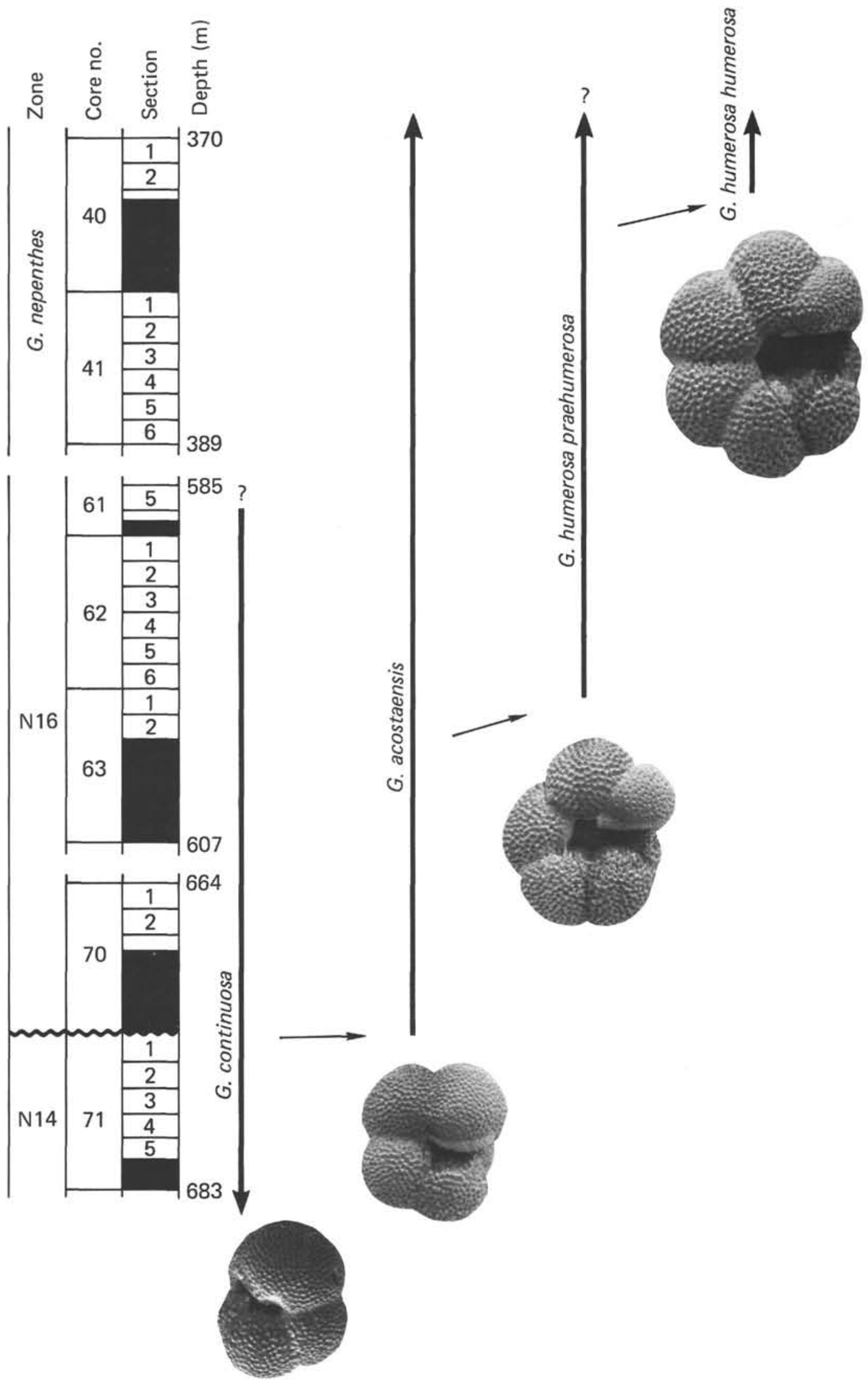

Figure 4. Globorotalia continuosa-G. humerosa humerosa lineage as recorded at DSDP Site 397. 

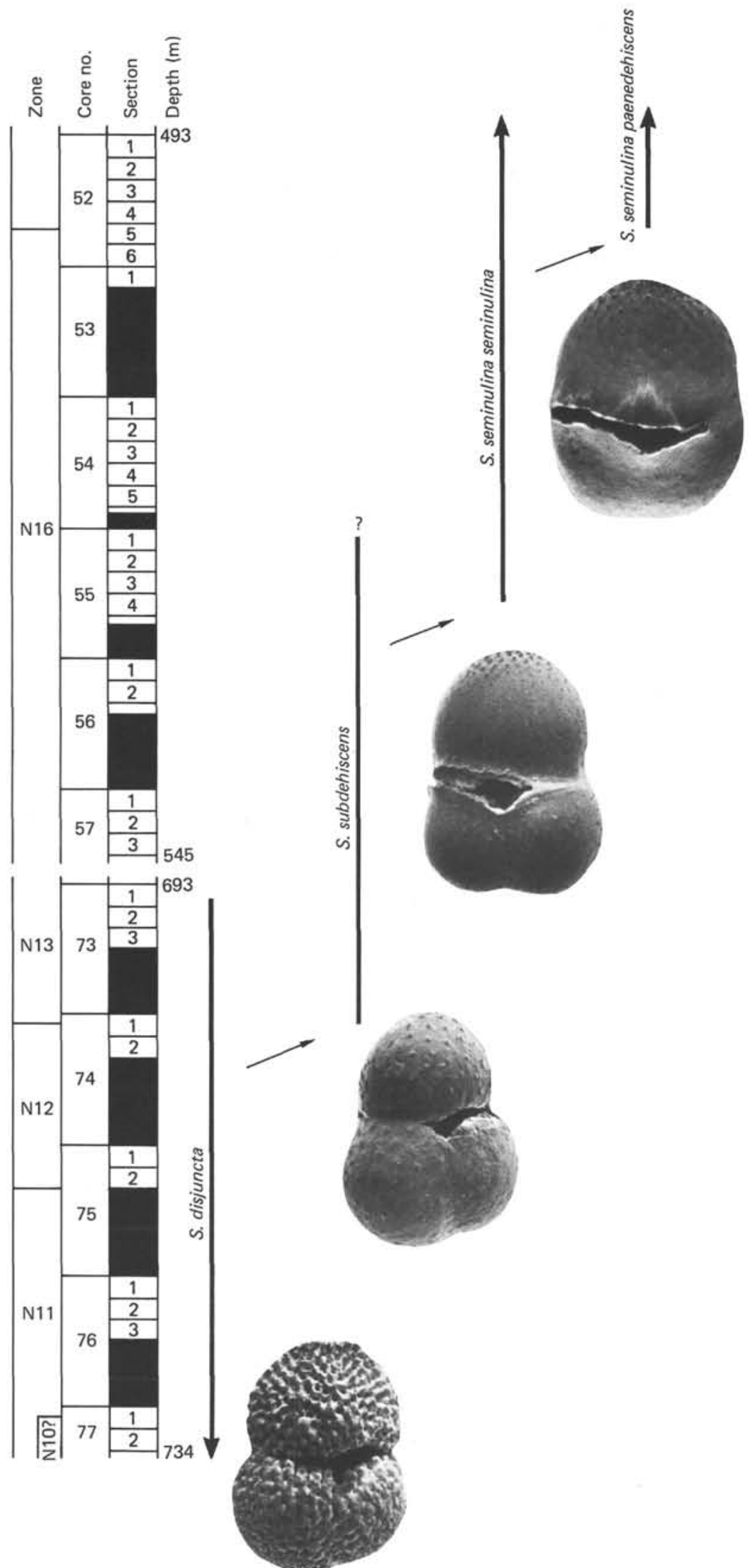

Figure 5. Sphaeroidinellopsis lineage as recorded at DSDP Site 397. 
ical in position, and the umbilical margins of the chambers are devoid of lips or flanges. The umbiculus in the four-chambered specimens is wider, the "aperture" less extended laterally and often entirely umbilical in position, with a higher arc; the last-formed chamber is often aberrant, smaller than the preceding one, slightly more compressed, and occasionally sacculiform; its ventral margin may develop a thickened and fimbriate edge. We identify this first step with $S$. disjuncta, originally described from the lower Miocene of New Zealand (Finlay, 1940; see also Hornibrook, 1958; and Jenkins, 1971). Though the holotype is a four-chambered specimen, the author originally also included three-chambered forms in the taxon under discussion. Several authors, including Brönnimann and Resig and Banner and Blow (1969) consider Finlay's species as a younger synonym of $S$. seminulina seminulina. With reference to Jenkins (1971), we do not accept this synonomy: the main differences between the two taxa concern external morphology, apertural characters, and wall structure. The assumption that the coarse-wall structure is related to decortication of the test is discarded because (a) the character is persistent, also in levels where there is no evidence of dissolution at depth, and (b) a gradual evolution of the biocharacter is observed leading to the second step of the lineage (see below). We consider it likely that "Globigerina" grimsdalei Keijzer from the Oligocene-Miocene of Cuba is a younger synonym of Finlay's species; the wall structure, the apertural characters, as well as the general morphology are identical to those observed in some variants of $S$. disjuncta. The range of $S$. disjuncta is from Cores 397-73 (N.13) to 97 (Zone N.7), predating the LAD of $G$. fohsi s.l. This range agrees well with that recorded in the type area of the taxon (New Zealand; see Jenkins, 1971).

The second step of the lineage is represented by $S$. subdehiscens. In Cores $397-73$ to 78 , we record a gradual trend: the first two chambers of the final whorl tend to become smoother. Starting from Core 397-76, the last chamber also becomes partially smooth. In this interval, the tests are less globular, slightly compressed laterally, the chambers are less spherical, and the sutures only slightly depressed. The ventral edges of the chambers gradually tend to be rimmed by a narrow, smooth, flat area. This holds true for both the threechambered specimens and the four-chambered ones. Starting from Section 397-74-1, the test becomes entirely smooth and has a glassy and polished appearance. Due to the importance that we attribute to the external cortex with respect to other biocharacters, we thus locate the second step in Section 397-74-1. The morphological features (discussed above) correspond to the definition of $S$. dehiscens subdehiscens Blow (1959), originally described from the middle Miocene Globorotalia mayeri Zone, G. mayeri-G. lenguaensis Subzone of the Pozon Formation, Venezuela, later referred by Blow (1969) to Zone N.13. S. dehiscens subdehiscens was considered by Blow (1969) as zonal marker of Zone N.13. With reference to the relative range of other species, including the Globorotalia fohsi and $G$. cultrata groups, we consider that the taxon under discussion very likely can be considered diagnostic of Zone N.13 also according to our own interpretation. The range of S. subdehiscens is from Core 397-55 (Zone N.17) to Section 397-74-1 (Zone N.13), in good agreement with the range given by Blow (1969). ${ }^{3}$

The third step of the lineage is represented by $S$. seminulina seminulina. From the FAD of $S$. subdehiscens to the top of the interval under discussion, we did not record any appreciable change in the structure of the cortex, which is persistently glassy and "polished." However, the following successive modifications of the free umbilical margins could be observed with the range $S$. subdehiscens: (a) in both the three-chambered and four-chambered specimens, the terminations of the chambers towards the umbilicus become increasingly developed and fringed, whereas the proximal edge of the last-formed chamber is like in S. subdehiscens; (b) the edge of the terminal chamber becomes more extended, and the fringed margins of the chambers preceding the last one tend to be projected outwards; (c) in both the three-chambered and four-chambered forms, the proximal edge of the last chamber displays a tendency to become projected outwards and crenulated (see Figure 5). The third characteristic (c) is shown clearly starting from Section 397-55-4; consequently, we locate here the third step of the lineage, which we identify with $S$. seminulina seminulina. ${ }^{4}$ The range of the taxon extends beyond the stratigraphic interval considered in the present study.

The fourth step is represented by $S$. seminulina paenedehiscens. S. seminulina seminulina initially retains the general morphological features proper of $S$. subdehiscens (test and chambers slightly compressed, equatorial periphery faintly lobulated, intercameral sutures slightly depressed). However, soon afterwards two groups of specimens become distinguishable. One maintains the characters of $S$. seminulina seminulina to the top of the interval considered, the only difference consisting of a more accentuated extension of the proximal edges of the chambers of the last whorl. A second

\footnotetext{
3 We consider it highly likely that Blow's species is a younger synonym of "Sphaeroidinella" rutschi Cushman and Renz, inasmuch as the four-chambered paratype figured by Renz (1948, pl. 10, fig. lc) is put by Blow (1969) in the synonomy of S. subdehiscens. Both the holotype and paratype of $S$. rutschi are from a level of the Pozon formation referred by Renz (1948) to the Marginulinopsis basispinosus Zone, and subsequently referred by Blow $(1959,1969)$ to the interval encompassing Zones N.14 to N.16. Though S. rutschi has priority, we keep the name subdehiscens because (a) the latter taxon has been widely used in the last decade, and (b) unlike the former, it has been described and figured with accuracy.

${ }^{4}$ This taxon has been neotypified by Banner and Blow (1960). Unfortunately, these authors selected from the metatypic collection a specimen with four chambers in the last-formed whorl, which is not diagnostic according to our observations. However, both the neotype and the holotype (which is three-chambered) correspond to the features which we consider characteristic of our third evolutionary step. The holotype is from the Neogene of Kar Nikobar. The neotype, which is from the same locality, is late Miocene (?) in age according to Banner and Blow (1960).
} 
group, along with a further development of umbilical flanges, displays a tendency of the test to become subglobular, less lobulated, and with less depressed sutures. Starting from Section 397-52-5 upwards, the morphological differences between the two groups are clearly evident: specimens referable to the second group (here identified as S. seminulina paenedehiscens display ovated, inflated test, strongly globular chambers, superficial and indistinct intercameral sutures. Only specimens with more than three chambers in the last whorl have slightly lobulated equatorial periphery, and depressed sutures in the terminal part. ${ }^{5}$

The holotype of $S$. seminulina paenedehiscens Blow is from Zone N.19 (Bowden Formation, Jamaica). S. sphaeroides Lamb is a junior synonym of the former, as pointed out also by Stainforth et al. (1975). $S$. seminulina paenedehiscens ranges from Sections 39733-1 (Zone N.19) to 397-52-5 (Zone N.17). During this range, an increase in the size of the test is recorded. In large-sized speciments, the free umbilical margins of the first and last chamber of the terminal whorl extend laterally so that they reach the dorsal peripheral shoulder.

An important step in this lineage consists in the acquisition of a supplementary aperture, which coincides with the FAD of the genus Sphaeroidinella (Zone N. 18/N.19 boundary), a biostratigraphic criterion used to identify the Miocene/Pliocene boundary (see Blow, 1969; Cita and Blow, 1969; Cita, 1975a).

The first local occurrence of Sphaeroidinella dehiscens forma immatura, as recorded in Sample 397-35, $\mathrm{CC}$, does not coincide with the FAD of Sphaeroidinella; it occurs close to the FAD of Globorotalia punciculata, well within Zone N.19. Representatives of the Sphaeroidinellopsis lineage are sporadically represented in the Cape Bojador drill site through Cores $397-35$ to 45 , so that we could not use this criterion to identify the Miocene/Pliocene boundary (see Chronostratigraphy).

\section{BIOCHRONOLOGY}

The zonal subdivision adopted here follows Blow's zonal scheme, which is generally accepted as a standard zonation for the Neogene, and is usually followed in DSDP volumes. The greatest difficulties in applying this zonation have been encountered in the upper Miocene and in the lower Pliocene, with special reference to the recognition of the N.16/N.17, N.17/N.18, and N.18/N.19 zonal boundaries. The first two boundaries are defined on the basis of Globorotalia tumida evolutionary lineage, which is incompletely developed at Site 397. Moreover, Zones N.16 and N.17 are both long duration zones (see Ryan et al., 1974) and the criterion on which their distinction is established is sub-

5 We considered seminulina and paenedehiscens at a subspecific level since the characters to which we attribute the greatest taxonomic importance in the Sphaeroidinellopsis lineage, i.e., structure of the cortex and apertural characters, are almost identical. ject to a certain degree of uncertainty, resulting from (a) the very gradational transition from $G$. merotumida to $G$. tumida plesiotumida, as already pointed out by several authors; and (b) the difficulty in discriminating the taxa under discussion from other keeled Globorotalias. On the other hand, we could not apply the detailed zonation recently proposed for the late Miocene of the Mediterranean by d'Onofrio et al. (1975), due to the recorded absence of the zonal markers.

The N.18/N.19 zonal boundary could not be pinpointed due to the delayed entrance of Sphaeroidinella dehiscens forma immatura at Site 397, as already mentioned.

As a result of (1) the difficulties in applying Blow's zonation to the succession of Cape Bojador, and (2) the inherent weakness of this zonation for the interval encompassing the upper Miocene and lower Pliocene, we are here introducing two new biozones as substitutes of Zones N.17, N.18, and part of N.19 of the standard zonation. The new biozones are here defined. They link Blow's zonation, which is excellent and can be easily applied for the rest of the Miocene with Cita's zonation (1972, emended 1975b) which also can be applied for the Pliocene outside the Mediterranean, the area for which Cita's zones were established.

Zone N.16: Globorotalia (Turborotalia) acostaensis acostaensis $G$. (G.) merotumida. Partial-Range Zone of Blow (1969), here emended. Interval from the first evolutionary appearance of $G$. acostaensis to the FAD of Sphaeroidinellopsis seminulina paenedehiscens.

Sphaeroidinellopsis seminulina paenedehiscens Partial-Range Zone, here proposed. Interval with the zonal marker from the FAD of the nominal taxon to the FAD of Globorotalia margaritae s. s.

Globigerina nepenthes Interval-Zone, here proposed. Interval with the nominal taxon from the FAD of Globorotalia margaritae s. s. to the FAD of $G$. puncticulata.

The biozones are briefly discussed here from bottom to top, with comments on the peculiarities, anomalies, and deficiencies they present in the section investigated. Reference is made to the general range chart (Figure 6) for a documentation of the taxa recorded in the over 230 samples investigated, and to Plates 1 to 14 for illustration of the stratigraphically most interesting, or most common, or rare but meaningful taxa. No taxonomical notes are included here, besides those already discussed and limited to a single evolutionary lineage.

Zone N.7: Globigerinatella insueta-Globigerinoides quadrilobatus trilobus. From Samples 397-97-1, CC to 397-90-2, $90-93 \mathrm{~cm}$ (922.3 to $856.9 \mathrm{~m}$ sub-bottom).

The lower boundary of this biozone is defined by the LAD of Globigerinita dissimilis s.l., which has not been recorded in any of the samples investigated. The upper boundary coincides with the FAD of Globigerinoides sicanus (see Plate 6, Figures 8 and 11; Plate 7, Figures 1 through 3 ). The latter taxon, however, has been recorded from earlier horizons of the early Miocene, starting from Zone N.6 (Brönnimann and Resig, 


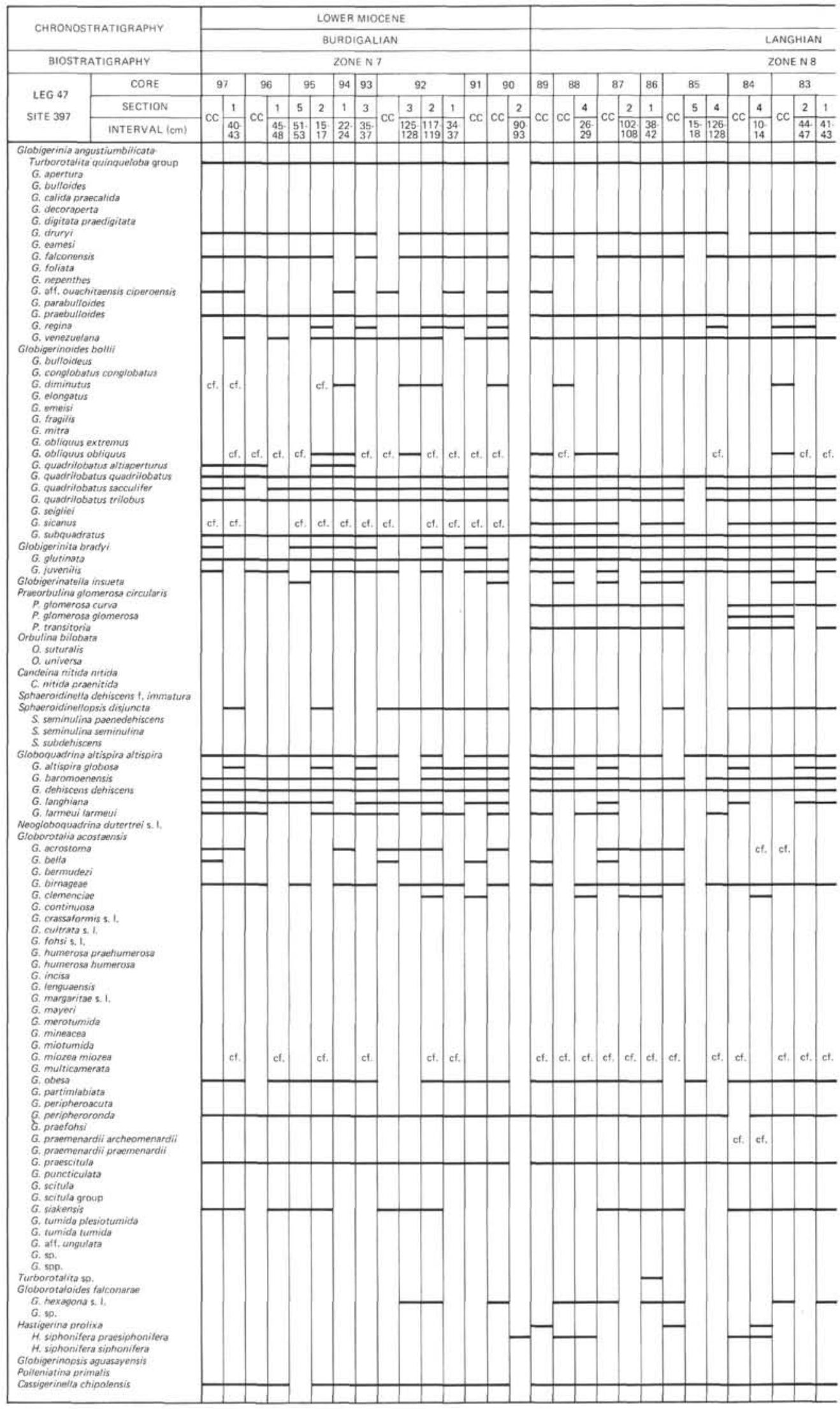

Figure 6. Distribution of selected foraminiferal species in Cores 397-97 through 33. 


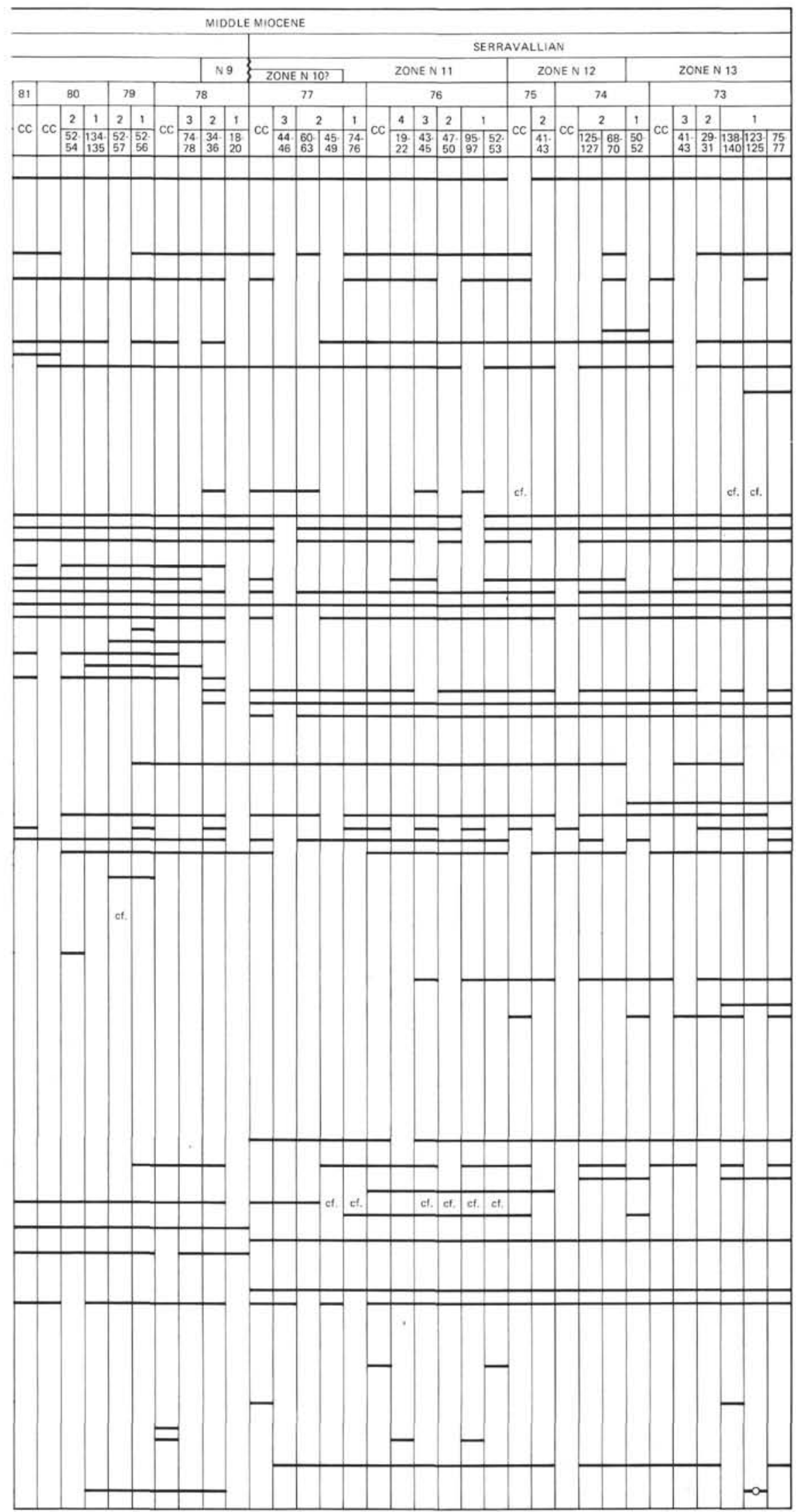

Figure 6. (Continued). 


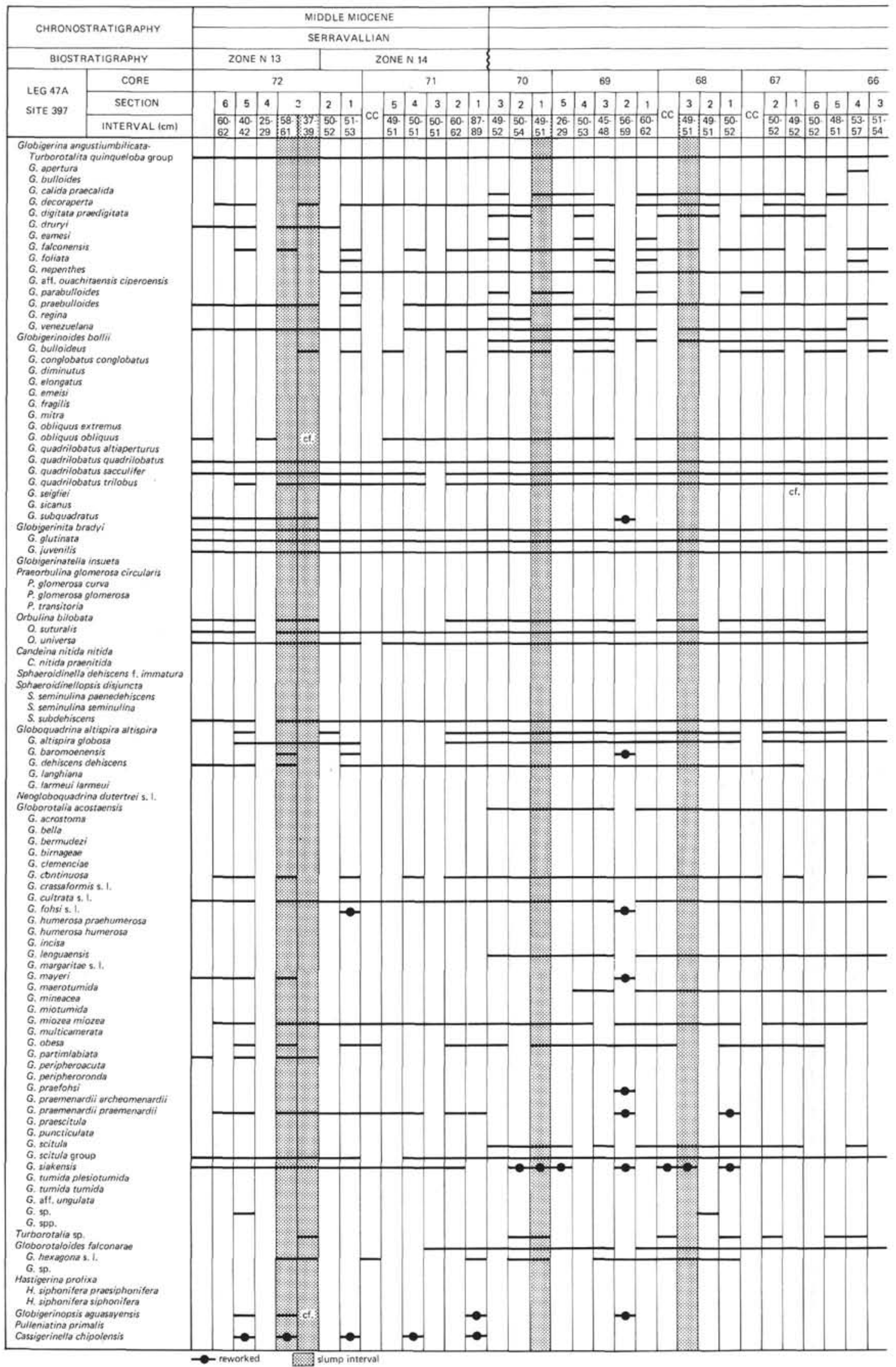

Figure 6. (Continued). 


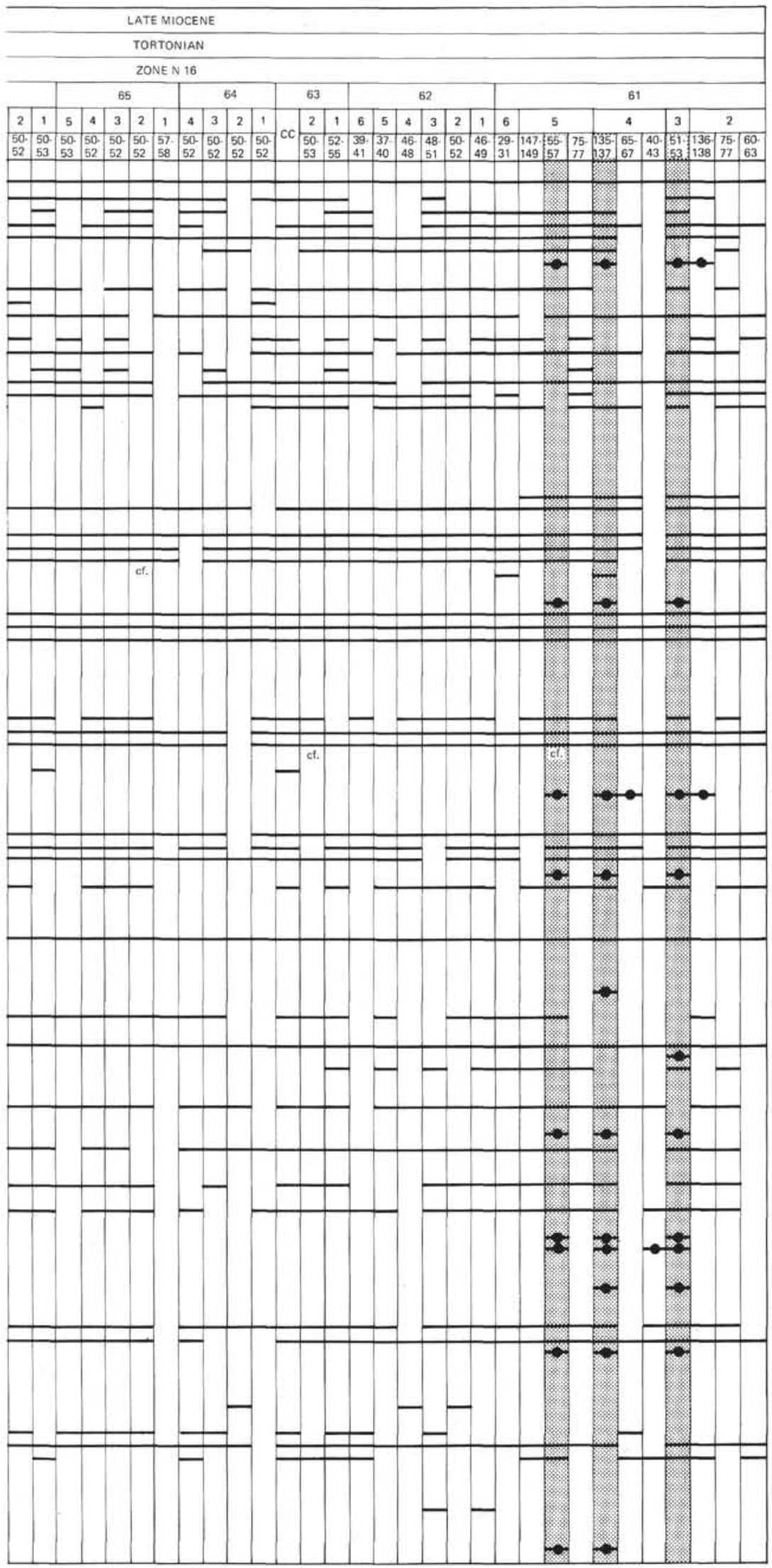

Figure 6. (Continued). 


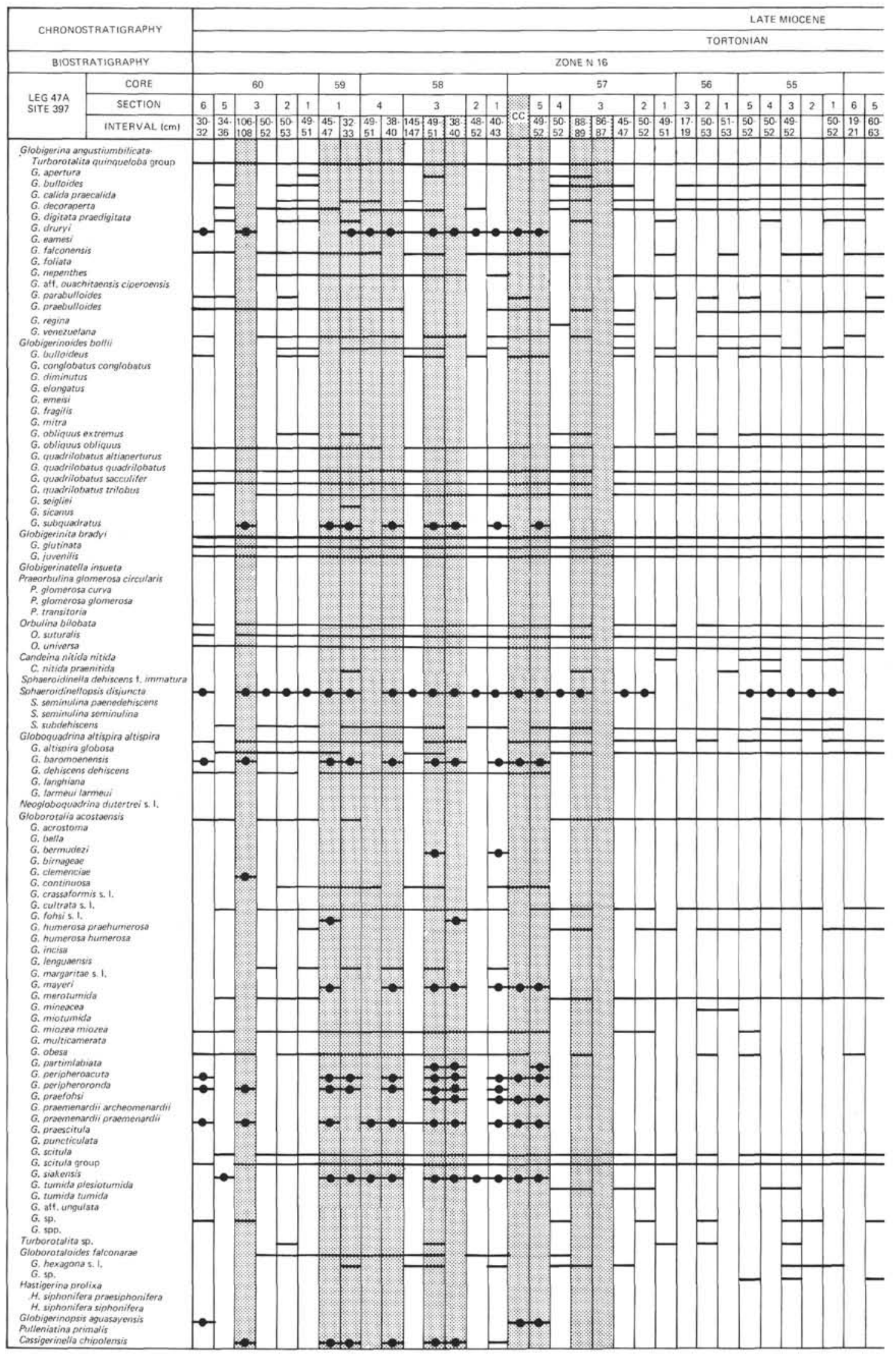

Figure 6. (Continued). 


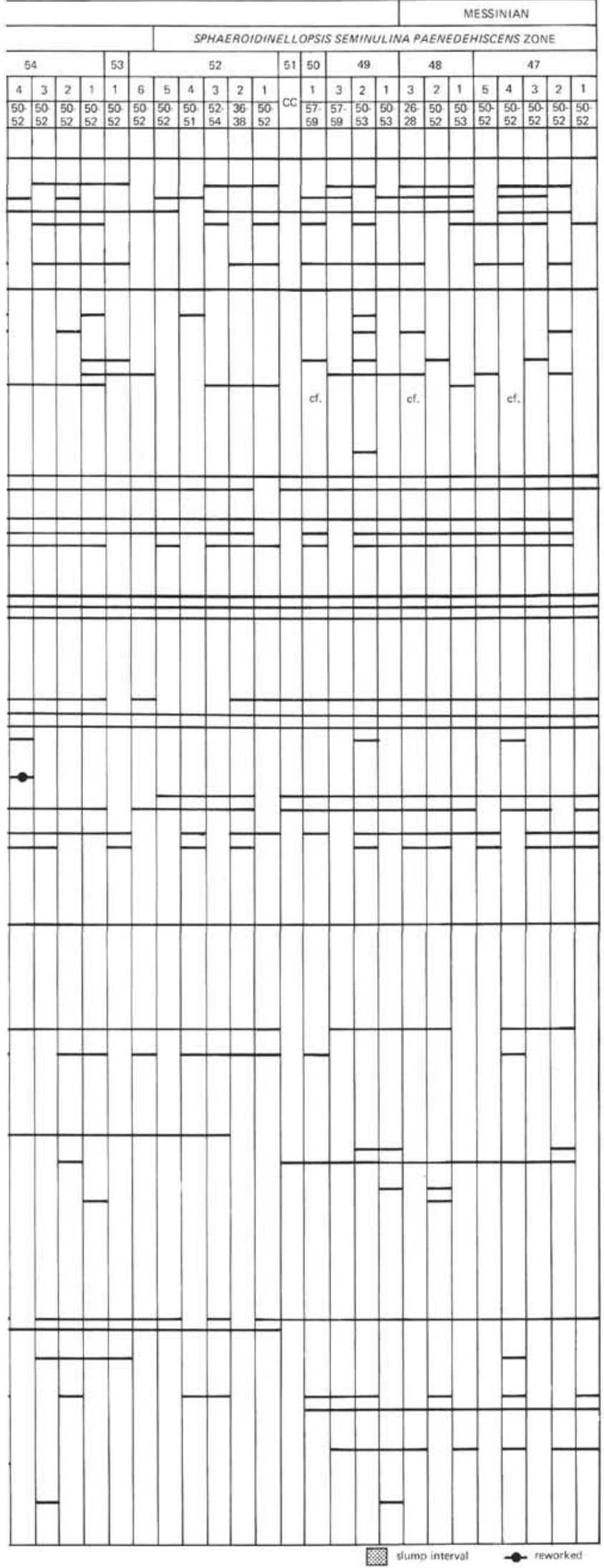

Figure 6. (Continued). 


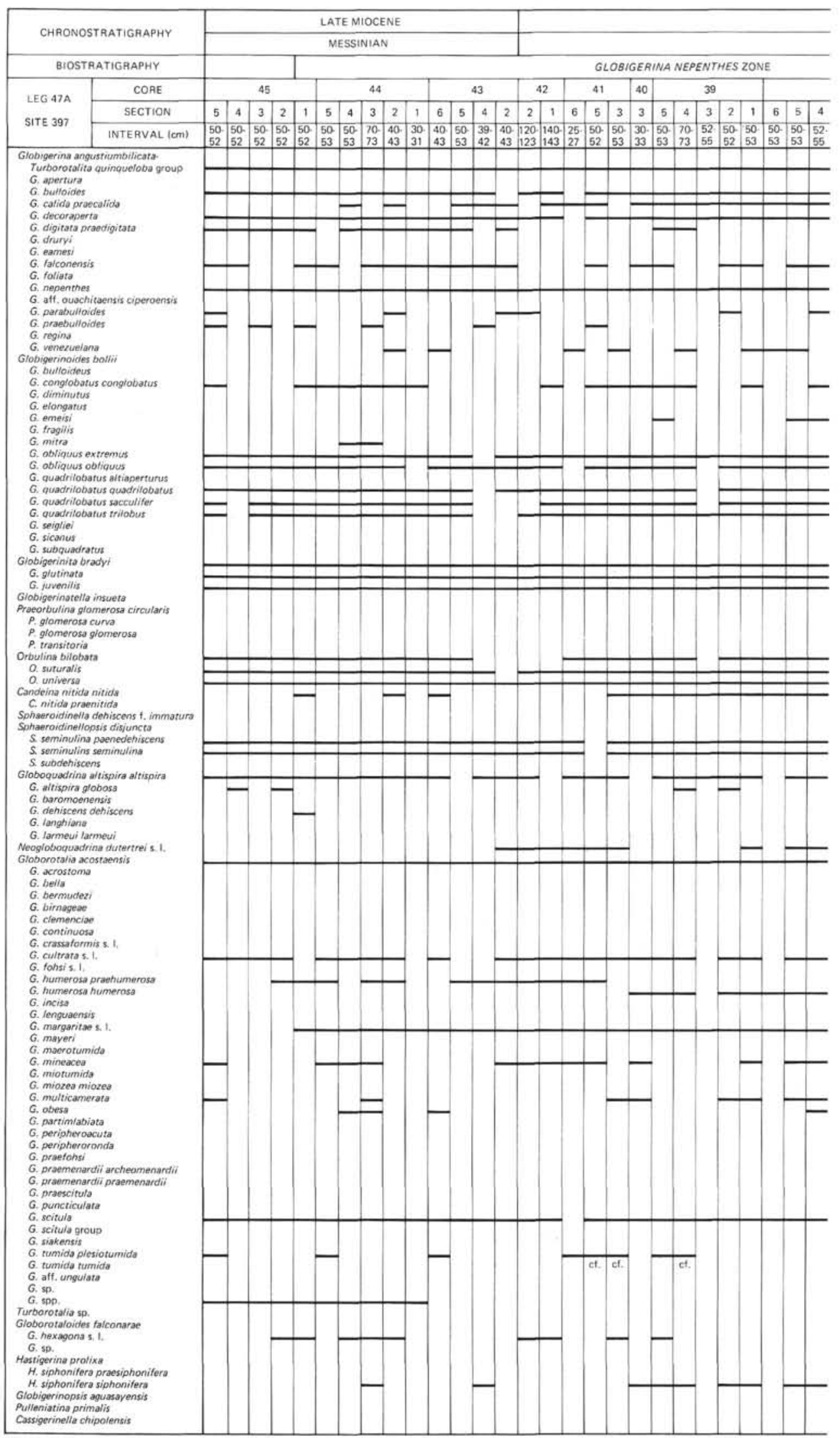

Figure 6. (Continued). 


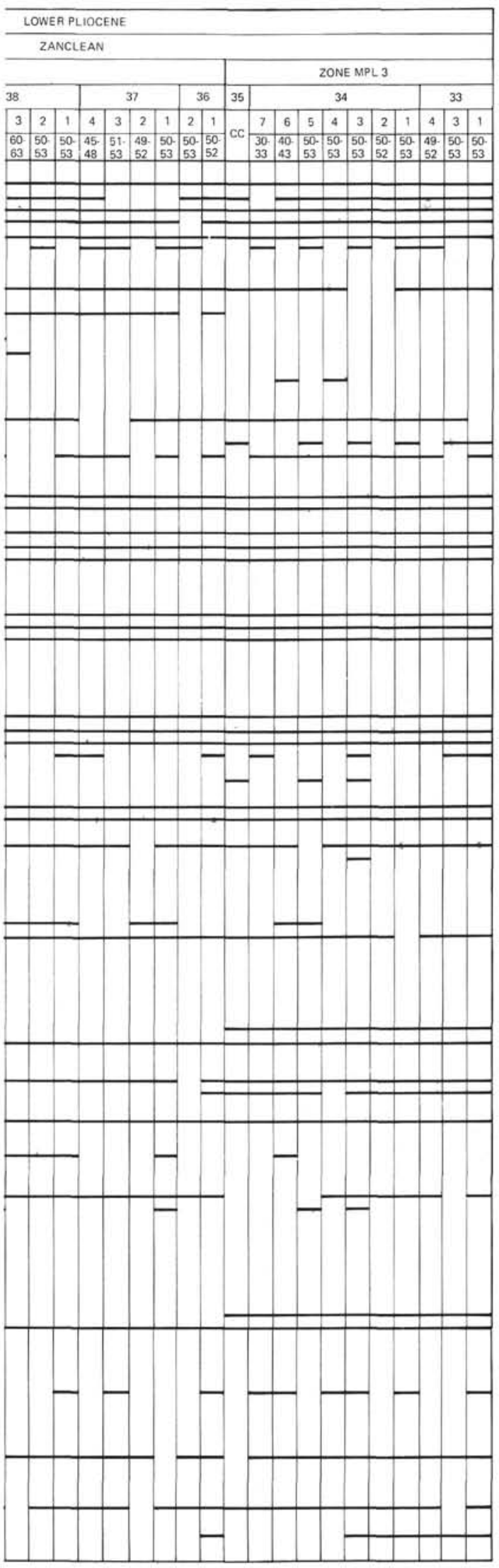

Figure 6. (Continued). 
1971), or from levels correlated with Zone N.7 (Stainforth et al., 1975). In the present paper, we locate the N.7/N.8 zonal boundary in coincidence with the FAD of the oldest typical specimens referable to $G$. sicanus, i.e., Sample 397-89-3, CC. Consequently, the underlying interval is referred to N.7. Rare, small specimens of Globigerinoides with three chambers in the last whorl, which can be compared with $G$. sicanus ( $G$. cf. sicanus of Figure 6), are recorded well below Core $397-89$, down to Section 397-A-17-3 which is 230 meters lower (see Site Report, this volume) The recorded occurrence, from Core 397-97 upwards, of Globorotalia birnageae (Plate 9, Figures 10, 15, and 16) and of Globigerinoides diminutus (Plate 8, Figures 14 and 15), both taxa first occurring in Zone N.7 according to Blow (1969), excludes an attribution to zones older than N.7.

One more item of supporting evidence is provided by the occurrence of Globigerinoides altiapertura (Plate 8 , Figures 6 through 9), which ranges up to Core 397 94. According to Blow (1969) this taxon disappears in the lower part of N.7. Taxa commonly recorded from this interval include the Globigerinoides quadrilobatus group; G. subquadratus (Plate 8, Figures 1 and 2); Globigerina praebulloides (Plate 1, Figure 5); Globorotalia praescitula (Plate 13, Figures 5 through 8); G. peripheroronda (Plate 11, Figures 1 through 3); Cassigerinella chipolensis (Plate 14, Figure 21); and (in some levels) Globoquadrina altispira s.l. and G. baromoenesis (Plate 3, Figure 15). Rare or sporadic are Globigerinatella insueta (Plate 2, Figure 16). Globoquadrina dehiscens dehiscens (Plate 3, Figure 11 including forma “'advena'). Globigerionoides obliquus obliquus (Plate 8, Figure 4; often non-typical, and indicated with cf. in the range chart); G. diminutus, G. altiapertura, Globigerina falconensis (Plate 2, Figure 15); G. druryi (Plate 1, Figures 9, 13, and 14); G. venezuelana (Plate 1, Figures 1, 2, and 4); Sphaeroidinellopsis disjuncta (Plate 4, Figures 13 through 17); Globorotalia siakensis (Plate 10, Figures 1 through 13); G. obesa (Plate 9, Figure 1); G. birnageae, G. clemenciae (Plate 8, Figures 23 and 24); G. cf. miozea (Plate 12, Figure 18; Plate 13, Figure 1; also, $G$. cf. praescitula of Walters, 1965); G. acrostoma (Plate 9, Figures 10 through 21);G. bella, Globoquadrina larmeui (Plate 3, Figures 4 and 5); G. langhiana (Plate 3, Figure 9).

Zone N.8: Globigerinoides sicanus-Globigerinatella insueta. From Samples 397-89-3, CC to 397-78-3, 74$77 \mathrm{~cm}$ ( 848.5 to $744.2 \mathrm{~m}$ sub-bottom).

The lower boundary of Zone N.8 coincides with the FAD of Globigerinoides sicanus; the upper boundary, with the FAD of Orbulina suturalis. Within this biozone, we recorded two parallel evolutionary lineages, one leading from Praeorbulina glomerosa curva (Plate 6, Figures 2, 3, and 5) to Orbulina suturalis, the other one from Praeorbulina transitoria (Plate 6, Figures 1 and 4) to $O$. bilobata (Figure 1). Also observed in this interval is the evolutionary trend leading from Globorotalia praescitula to G. praemenardii archaeomenardii (Plate 13, Figures 9 through 13). Taxa commonly recorded from this biozone include Globigeri- noides sicanus, G. subquadratus, G. quadrilobatus s.1., Globigerina falconensis, $G$. praebulloides, $G$. venezuelana, Globorotalia siakensis, G. praescitula, Praeorbulina spp., Globoquadrina altispira s.l., G. baromoenesis, and (in some samples) Sphaeroidinellopsis disjuncta, Cassigerinella chipolensis, Globoquadrina dehiscens dehiscens, Globigerina druryi, Globorotalia birnageae, $G$. peripheroronda. Usually rare are Globigerinatella insueta, Globorotalia praemenardii archaomenardii (Plate 13, Figures 9 through 13), G. cf. miozea, G. clemenciae, and G. acrostoma. Occasionally recorded are Hastigerina siphonifera praesiphonifera (Plate 2, Figures 23 and 24); Bolliella prolixa (Plate 2, Figures 5 and 6); Globigerinoides diminutus, G. obliquus obliquus, Globoquadrina larmeui, and $G$. langhiana.

Zone N.9: Orbulina saturalis-Globorotalia (Turborotalia) peripheroronda. From Samples 397-78-2, cm to $397-78-1,18-20 \mathrm{~cm}$ (742-3 to $740.6 \mathrm{~m}$ sub-bottom).

The lower boundary of Zone N.9 coincides with the FAD of Orbulina saturalis; the upper boundary, with the FAD of Globorotalia peripheroacuta (Plate 11, Figures 4 through 6, and 10). At Site 397, this latter taxon is recorded starting from Sample 397-77, CC. Consequently, only Sections 1 and 2 of Core 397-78 are referable to Zone N.9. The extremely small thickness of this biozone, given the high sedimentation rate type of this setting at the foot of a continental slope, is suggestive of a hiatus. Additional biostratigraphic observations supporting the existence of a hiatus immediately beneath Core 397-77 are discussed in the Site Report (this volume). This hiatus probably corresponds to the greatest part of Zone N.9 and to most of Zone N.10.

In this short interval, we recorded the first occurrence of Orbulina bilobata. Globorotalia peripheroronda (Plate 11, Figures 1 through 3 ) shows a tendency to develop a compressed periphery in the last few chambers. Among the Praeorbulinas, only P. glomerosa circularis (frequent; see Plate 6, Figure 10 ) and $P$. transitoria (rare) persist, along with the last specimens referable to Cassigerinella chipolensis, Globigerinoides sicanus, Globorotalia praemenardii archaomenardii, and G. praescitula. Some of these taxa have been recorded from younger levels; however, they are interpreted as either reworked, or involved in slumps.

Zone N.11: Globorotalia (G.) praefohsi. From samples $397-77-1,74-76 \mathrm{~cm}$ to $397-76-1,52-56 \mathrm{~cm}$ (731.7 to $722.5 \mathrm{~m}$ sub-bottom).

The lower boundary is defined by the FAD of $G$. praefohsi (Plate 11, Figures 7 through 9), evolving from its ancestor, G. peripheroacuta (Plate 11, Figures 4 through 6, and 10); the upper boundary by the FAD of $G$. fohsi s. s. These two biostratigraphic events have been recorded, respectively, in Samples 397-77-1, 74$76 \mathrm{~cm}$, and $397-75, \mathrm{CC}$. The interval immediately under lying, from Samples 397-77-2, $45-49 \mathrm{~cm}$, to 397-77, CC (an interval yields $G$. peripheroacuta without $G$. praefohsi), should be referred to Zone N.10. This attribution, however, is very uncertain because this interval is very unfavorable to the investigations on this lineage of Globorotalias: specimens referable to the Globorotalia fohsi plexus (Plate 11, Figures 11 through 
16 and 19) are sparse and poorly preserved. Consequently, we cannot rule out the possibility that the zonal boundary lies somewhat lower, in Core 397-77. A purely paleontological argument supporting this doubt is the recorded occurrence of a highly evolved form of $G$. praemenardii (i.e., with limbated spiral and intracameral sutures in the penultimate whorl) starting from Sample 397-77-3, CC. According to Blow (1969), the acquisition of this biocharacter in the lineage under discussion is realized within Zone N.11. In conclusion, we refer to Zone N.11 as the interval from Samples $397-77-1,76 \mathrm{~cm}$ to $397-76-1,52 \mathrm{~cm}$, but allow that all of Core 397-77 may fall within this biozone.

Within this interval, we record the first local appearance of Globorotalia praemenardii praemenardii (Plate 13, Figures 14 through 21; Plate 14, Figure 1), Orbulina universa, G. continuosa (Plate 10, Figures 3 and 4), and Globigerinopsis aguasayensis (Plate 3, Figures 1 through 3); Globorotalia peripheroronda, on the contrary, becomes progressively rare and less typical, disappearing at the top of the zone. Taxa common or frequent include Orbulina spp., Globoquadrina baromoenensis, G. altispira s.1., Globigerinoides quadrilobatus s.l., Globigerina druryi, G. venezuelana, Sphaeroidinellopsis disjuncta, Globorotalia siakensis, G. praemenardii praemenardii, G. miozea moizea (typical from this interval upwards; see Plate 13, Figures 2 through 4), and $G$. scitula group. Also common in some levels are Globoquadrina dehiscens dehiscens, Globigerina praebulloides, Globorotalia peripheroacuta (in the later part of the interval), and Globigerinopsis aguasayensis. Globigerinoides subquadratus, Globigerina falcenensis, and Globorotalia praefohsi are rare; Hastigerina siphonifera praesiphonifera and Globigerinoides obliquus obliquus are sporadic.

Zone N.12: Globorotalia (G.) fohsi. From samples $397-75$, CC to $397-74-2,68-70 \mathrm{~cm}$ (715.1 to $704.6 \mathrm{~m}$ sub-bottom).

The FADs of Globorotalia fohsi s.s. and of Sphaeroidinellopsis subdehiscens (Plate 4, Figures 18 through 20) characterize, respectively, the lower and upper boundary of this biozone. The FAD of the latter taxon has been recorded in Sample 397-74-1, 50-52 cm. We acknowledge that out interpretation of this taxa of the Sphaeroidinellopsis lineage differs in part from that of Blow (1969), but we believe that our position does not affect the biostratigraphic interpretation of this interval. The above assumption is supported by the range of Globorotalia praefohsi (Plate 11, Figures 17 and 18), G. fohsi, G. praemenardii praemenardii, G. cultrata s.l. (Plate 14, Figures 2 through 4, and 6), Globigerina decoraperta (Plate 1, Figures 11 and 12). In other words, we consider the N.12/N.13 boundary as defined by Blow (1969).

The preservation of foraminiferal tests is poor in most cases; the best represented taxa include Globorotalia siakensis, G. praemenardii praemenardii, G. scitula group, Globigerina venezuelana, Globigerinoides quadrilobatus s.1., and Orbulina spp. In some samples, we also recorded an abundance of Globoquadrina dehiscens dehiscens, G. altispira s.l., Globigerina druryi, G. falconensis, G. praebulloides, Sphaeroidinellopsis disjuncta (with transitional forms to $S$. subdehiscens). $G$. miozea miozea, and G. continuosa. Within this interval, Globorotalia peripheroacuta disappears; taxa of the $G$. fohsi lineage, Globigerinoides subquadratus, and Globoquadrina baromoenensis are seldom recorded; and Globorotalia partimlabiata (Plate 9, Figures 11, 17, and 18) first appears.

Zone N.13: Sphaeroidinellopsis subdehiscens subdehiscens-Globigerina druryi. From Samples 397-74-1, $50-52 \mathrm{~cm}$ to $397-72-3,37-39 \mathrm{~cm}$ (703 to $686.3 \mathrm{~m}$ subbottom).

The lower boundary of this zone is defined by the FAD of S. subdehiscens; the upper one, by the FAD of Globigerina nepenthes (Plate 1, Figure 19; Plate 2, Figures 1 and 2). Within this interval, specimens ex interc $G$. druryi-G. nepenthes (very close to the latter taxon) are recorded. As previously mentioned, we located the FAD of $G$. nepenthes (i.e., Zone N.13/N.14 boundary) where typical, well-developed specimens are commonly recorded. Globorotalia siakensis, G. scitula group, G. partimlabiata, Sphaeroidinellopsis subdehiscens, Globigerinopsis aguasayensis, Orbulina spp., Globigerinoides quadrilobatus, and occasionally Globorotalia continuosa, G. miozea miozea, Globigerina venezuelana, G. druryi, Globoquadrina altispira s.1 are common to abundant. Globogerinoides obliquus obliquus and $G$. bulloides are sporadic.

Within this interval, we recorded the FADs of Globorotalia cultrata s.I. and of Globigerina decoraperta. Taxa which disappear within Zone N.13 are Globorotalia fohsi (Plate 11, Figures 11 through 16, and 19; Plate 12, Figures 1, 2, and 5) with the forms "lobata" and "robusta," $G$. praefohsi, Sphaeroidinellopsis disjuncta, Globorotalia partimlabiata, Globigerinoides subquadratus, and Globigerinopsis aguasayensis. Typical specimens of Globorotalia mayeri (Plate 9, Figures 5, 9, and 12 through 14) were recorded only from this interval.

Zone N.14: Globigerina nepenthes/Globorotalia siakensis. From Samples 397-72-2, 50-52 cm to 397$71-1,87-89 \mathrm{~cm}$ ( 685.5 to $674.8 \mathrm{~m}$ sub-bottom).

This biozone is defined at its base by the FAD of $G$. nepenthes and at its top by the LAD of $G$. siakensis. In our cores, we also recorded G. siakensis from Cores 397-70-to 68. We referred these cores to Zone N.16 because of the occurrence of Globorotalia acostaensis (see discussion under Reworking in the Site Report, this volume). G. siakensis is interpreted as being reworked.

Globorotalia cultrata s.l. (Plate 14, Figures 2 through 4, and 6). G. siakensis, G. miozea miozea, Globigerina nepenthes, Globoquadrina dehiscens, Sphaeroidinellopsis subdehiscens, Globigerina praebulloides, Globigerinoides quadrilobatus s.l., and Orbulina spp. are the most common taxa. Rare are Globigerina decoraperta, G. falconensis, Globorotalia continuosa, Globigerinoides obliquus obliquus, G. bulloideus (Plate 8, Figures 10 and 11 ), and Globoquadrina altispira s.1. Within this interval, we recorded the last occurrence of Globigerina druryi and Globoquadrina baromoenensis, 
and the first occurrence of Globorotaloides falconarae (Plate 4, Figures 5 through 7).

Zone N.16: Globorotalia (Turborotalia) acostaensis acostaensis-Globorotalia (T.) merotumida. From Samples $397-70-3,49-52 \mathrm{~cm}$ to $397-52-6,50-52 \mathrm{~cm}$ (668.4 to $501.5 \mathrm{~m}$ sub-bottom).

This zone, defined by Blow (1969) as the interval from the FAD of $G$. acostaensis to the FAD of $G$. $t u$ mida plesiotumida, is here amended in its upper limit, which is defined by the FAD of Sphaeroidinellopsis seminulina paenedehiscens (Plate 5 , Figures 3 , and 5 through 11). This taxon is easily recognizable and the interval with transitional forms "seminulina s.s."-"paenedehiscens" is very short. The FAD of the latter taxon slightly postdates that of Globorotalia tumida plesiotumida (Plate 12, Figures 10 through 14, and 19), but the reliability of the specific identification is by far larger.

A hiatus occurs between Cores 397-71 and 70; consequently, the FAD of $G$. acostaensis (Plate 10, Figures 5 and 6 ) is not really controlled on an evolutionary lineage. Specimens transitional from $G$. continuosa to $G$. acostaensis are recorded in Cores 397-70 and 69; therefore, if the record of Zone N.16 is incomplete at its base, the missing part should be extremely short.

The interval referred to Zone N.16 is strongly affected by slumps (Cores 397-70, 68, and especially 61 to 57). Samples from slump intervals are shaded in the range chart (Figure 6). Reworking also has been noticed at various intervals. Many taxa, due to their biochronological significance, certainly have to be considered allochthonous: they are indicated with $\bullet$ in the range chart.

Several first occurrences are recorded in this interval. From bottom to top they are Globerigina digitata praedigitata (Plate 1, Figures 7 and 8); G. calida praecalida (Plate 1, Figures 3 through 6); Globorotalia lenguaensis (Plate 9, Figures 2 through 4); G. scitula s.s., Globigerinoides bollii (from the base of the interval; see Plate 8, Figures 12 and 13); Globigerina apertura (Plate 1, Figures 10 and 15); G. bulloides (Plate 2, Figure 3); Candeina nitida praenitida (Plate 3, Figure 12); Globorotalia humerosa praehumerosa (Plate 10 , Figures 7 and 8); Globigerinoides seiglei (Plate 7, Figures 12 and 13); Gl. obliquus extremus (Plate 8, Figure 3); Globorotalia tumida plesiotumida, Candeina nitida nitida, Globorotalia mineacea (Plate 10, Figures 14 and 15); Sphaeroidinellopsis seminulina seminulina, and Globorotalia miotumida (Plate 12, Figures 3, 4, and 9). Some of these have to be considered as local occurrences, others as first evolutionary appearances; the latter include G. nitida nitida (Plate 3, Figure 13), G. obliquus extremus, and G. bulloides.

Taxa common to frequent in this interval include Globorotalia acostaensis (rare in the earlier part only), $G$. cultrata s.l., G. lenguaensis (limited to the lower part), Sphaeroidinellopsis subdehiscens, Globigerina decoraperta, G. nepenthes, G. falconensis, Globigerinoides bulloideus, G. obliquus obliquus, G. quadrilobatus s.l., and Globoquadrina altispira s.l. Globorotalia continuosa, G. mineacea, Globigerina venezuelana, $G$. apertura, Globigerinoides bollii, G. bulloideus, and Globorotaloides falconarae are only occasionally common. Other taxa recorded from this interval are rare or sparse.

Several species Globorotalia lenguaensis, G. continuosa and Globorotaloides falconarae disappear in the middle part of this interval. The precise location of their last occurrences, however, cannot be recognized because of the slumps. Globorotalia miozea miozea and Sphaeroidinellopsis subdehiscens disappear in the latest part of the interval.

The coiling direction of G. acostaensis in Zone N. 16 is initially dextral (Cores 397-70 to 67), then consistently sinistral with two short duration reversals within Cores 397-64 and 61.

Sphaeroidinellopsis seminulina paenedehiscens Zone (here proposed). From Samples 397-52-5, $50-52 \mathrm{~cm}$ to $397-45-2,50-52 \mathrm{~cm}$ ( 500 to $419 \mathrm{~m}$ sub-bottom).

FAD of $G$. margaritae coincides with the first occurrence of typical specimens, definitely keeled and sinistral. Specimens similar to G. margaritae (fully keeled but consistently right-coiling) are recorded several meters deeper, within the bioseries leading to $G$. margaritae.

This interval is affected by strong dissolution; as a consequence the assemblages are often poorly diversified and usually sparse. Taxa recorded with a certain abundance are Globigerina nepenthes and Globorotalia acostaensis. In the interval from Sections 397-50-1 to 47-3 Globorotalia miotumida is also consistently recorded. Globigerinoides obliquus extremus, G. obliquus obliquus, G. bulloideus, G. quadrilobatus s.1., Globoquadrina altispira s.l., Globigerina decoraperta, G. falconensis, Orbulina spp., and Sphaeroidinellopsis seminulina paenedehiscens are only occasionally common in this interval. The last form increases gradually in size.

Within this interval, Globorotalia miotumida, G. merotumida (Plate 12, Figures 15 through 17), and Globigerinoides bulloideus disappear; Globorotalia multicamerata (Plate 14, Figures 5, 7, and 8) and Globigerinoides conglobatus (Plate 7, Figures 10 and 11) first occur. From Core 397-50 upwards we recorded a stock of Globorotalias which gradually evolve to $G$. margaritae (Plate 10, Figures 20 and 21). A change in coiling direction (from left-coiling to right-coiling) is recorded in G. acostaensis, which is consistently dextral in the later part of the interval, from Section 397-47-2 upwards.

Globigerina nepenthes Zone (here proposed). From Samples $397-45-1,50-52 \mathrm{~cm}$ to $397-36-1,50-52 \mathrm{~cm}$ (418 to $332.5 \mathrm{~m}$ sub-bottom).

This interval, which we have defined previously as spanning from the FAD of $G$. margaritae to the FAD of G. punctitulata, is strongly affected by dissolution at depth.

Among the best represented taxa are Globorotalia acostaensis, G. cultrata s.l., G. margaritae, G. humerosa 
s.s., Globigerina nepenthes, G. falconensis, G. bulloides, Globigerinoides obliquus extremus, G. quadrilobatus, and Orbulina spp.

Sphaeroidinellopsis seminulina paenedehiscens, Globorotalia scitula s.s., G. multicamerata, Hastigerina siphonifera s.s., Globigerina calida praecalida, and Globoquadrina altispira (group) are only occasionally common. Rare are Sphaeroidinellopsis seminulina seminulina, Globorotalia mineacea, and G. tumida plesiotumida; sparse are Candeina nitida nitida, Globigerinoides conglobatus, G. mitra, Globigerina apertura, $G$. venezuelana, and $G$. digitata praedigitata.

The following first occur within this inverval, from bottom to top: Neogloboquadrina dutertrei s.l. (Plate 10, Figures 16 through 18); Globorotalia $\mathrm{cf}$. tumida tumida, G. humerosa s.s. (Plate 10, Figures 9 and 10); Globigerinoides emeisi (Plate 8, Figure 5); Globorotalia aff. ungulata (Plate 12, Figures 6 through 8); G. incisa (Plate 8, Figures 20 through 22); and Pulleniatina primalis (Plate 4, Figures 10 through 12).

In the lower part of this zone, the following disappear: Globigerinoides bollii, G. tumida plesiotumida, and the plexus of Globorotalia spp. (Plate 8, Figures 16 through 19).

M P1 3 Zone (of Cita, 1975b): Globorotalia margaritae-G. puncticulata Concurrent-Range Zone. From Sample 397-51, CC to Section 397-33-1, i.e., to the topmost part of the interval considered here ( 323.1 to $304 \mathrm{~m}$ sub-bottom). At the base of the interval, along with G. puncticulata (Plate 9, Figures 22 through 24), the following first occur: G. crassaformis (Plate 9, Figure 25); Globigerinoides elongatus (Plate 7, Figures 4 through 7); and Sphaeroidinella dehiscens immatura (Plate 5, Figure 12). Since Core 397-35 has a very limited recovery, the contemporaneous appearance of several taxa (which in itself is suggestive of a hiatus) might be misleading. The best-represented taxa in this interval include $G$. puncticulata, G. margaritae cum var., G. cultrata s.l. (Plate 4, Figures 2 through 4, 6); G. acostaensis, G. humerosa (Plate 10, Figures 9, 10); G. scitula (Plate 10, Figure 19); Sphaeroidinellopsis seminulina paenedehiscens, Globigerina apertura, G. decoraperta, G. calida praecalida, G. bulloides, Globigerinoides obliquus extremus, G. quadrilobatus, andOrbulina spp. Rare to sparse are Pulleniatina primalis, Candeina nitida nitida, Globorotaloides hexagona (Plate 4, Figures 8, 9), Globoquadrina altispira altispira, Globigerinoides conglobatus, $G$. elongatus, Globigerina venezuelan, G. digitata praedigitata, Sphaeroidinella dehiscens immatura, and Globorotalia aff. ungulata.

\section{CHRONOSTRATIGRAPHY}

The Cape Bojador succession here considered is correlatable with the following standard stages of the Neogene, listed from bottom to top:

Burdigalian: from Sample 397-97, CC (Zone N.7)

to Secton 397-90-2 (Zone N.7)

Langhian: from Sample 397-89, CC Zone N.8) to Section 397-78-1 (Zone N.9),
Serravallian: from Sample 397-77, CC (Zone N.10, pars, or N.11) to Section 397-71-1 (Zone N.14), Tortonian: from Section 397-70-3 (Zone N.16) to Section 397-49-1 S. seminulina paenedehiscens Zone),

Messinian: from Section 397-48-3 ( $S$. seminulina paenedehiscens Zone) to Section 397-43-2 (Globigerina nepenthes Zone),

Zanclean: from Section 397-42-2 (G. nepenthes Zone) to Section 397-33-1 (M P1 3 Zone).

The correlation as indicated above is easy and immediate if we consider the results of the following investigations on the stratotype sections: Demarcq et al. (1974) for the Burdiglian; Cita and Blow (1969) and Ryan et al. (1974) for the Langhian, Serravallian, Tortonian, and Messinian; Cita (1972, 1975a), Cita and Gartner (1973), Cita and Decima (1975) for the Zanclean.

The positioning of the stratotype sections of these stages with reference to the standard foraminiferal zonation has been thoroughly discussed by Cita and Blow (1969) and by Ryan et al., (1974).

Figure 7 shows the calibration of the standard foraminiferal zones (represented in time-equivalent spacing in the central column) to the paleomagnetic stratigraphy (column to the left). The different inclinations of the lines connecting the foraminiferal zonal boundaries, from the time-equivalent spacing to their actual position recorded in the continuously cored succession penetrated at Site 397 , permit the identification of minor hiatuses related to submarine erosion.

Special attention has been paid to the correlation of the Tortonian/Messinian and Messinian/Zanclean (i.e., Miocene/Pliocene) boundary: they define a time interval during which the Mediterranean was affected by a basin-wide salinity crisis. The problem of the Tortonian/Messinian boundary, which for years was subject to controversy even after the designation of a neostratotype section in Sicily (Selli, 1960; d'Onofrio, 1964) recently has been examined by d'Onofrio et al. (1975). After investigations of several sections collected in Italy, these authors showed that the FAD of Globorotalia conomiozea was a most significant and readily recognizable biostratigraphic event, and the most important event occurring close to that boundary. Other biostratigraphic criteria used to correlate the boundary are the FADs of Globorotalia mediterranea, ${ }^{6}$ G. saheliana, and G. saphoae.

However, none of these criteria could be applied to the Cape Bojador succession, because of the absence of these species, which either are endemic to the Mediterranean (i.e., the last three species mentioned above have never been recorded outside the Mediterranean) or might be climatically excluded (e.g., G. conomiozea).

The Tortonian/Messinian boundary was located at Site 397 by means of calcareous nannofossils: first evolutionary appearance of Amaurolithus delicatus, re-

\footnotetext{
${ }^{6}$ While the present paper was in press, a publication by $\mathrm{W}$. H. Berggren (Marine Micropaleontology, v. 2, p. 265-313) showed that $G$. mediteranea is present also in the South Atlantic, thus refuting the first alternative.
} 


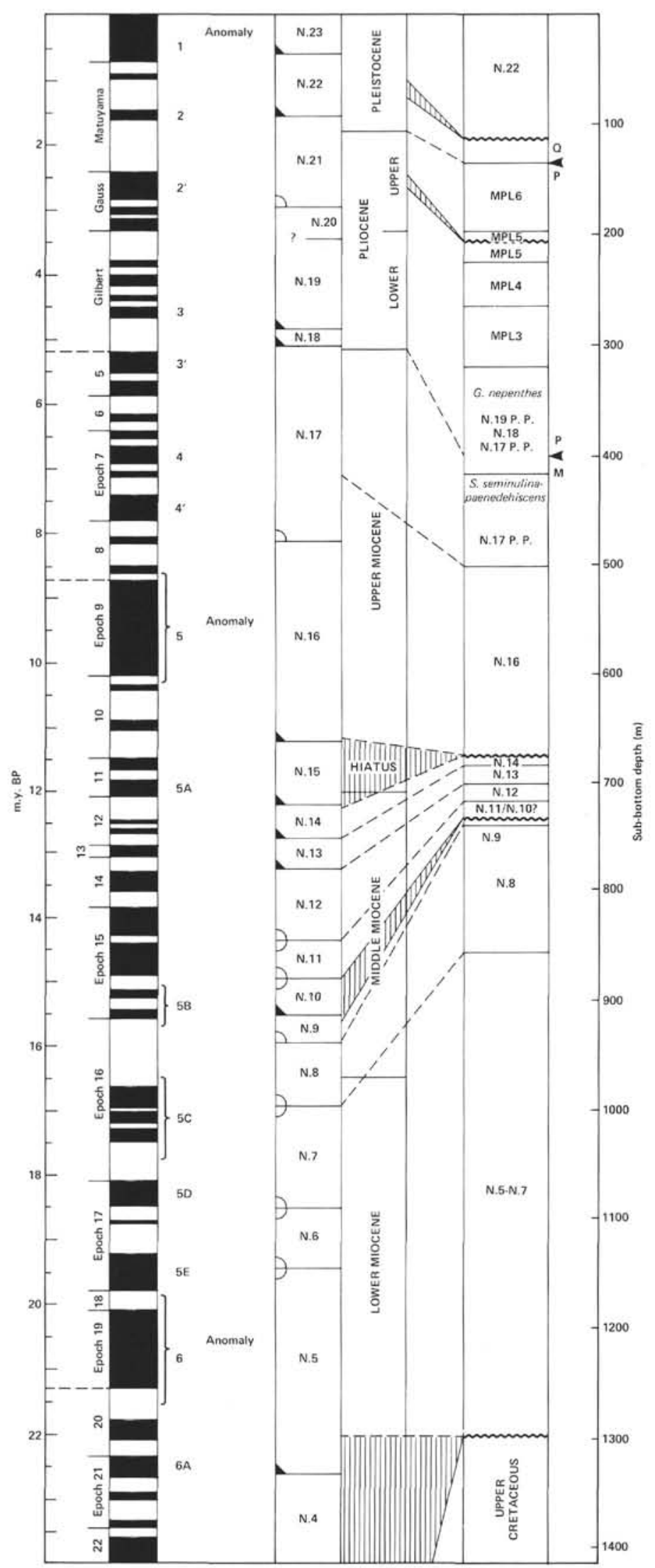

Figure 7. Calibration of the Neogene section continuously cored at DSDP Site 397 with the time-scale of Ryan et al. (1974) by means of planktonic foraminiferal zonal boundaries. 
corded at the base of Core 397-48, and correlated with the Bou Regreg section of Morocco (Bossio et al., 1976) at approximately the same level where $G$. conomiozea first occurs in that section (see Mazzei et al., this volume). A biostratigraphic event which proved very useful for correlation is a sudden coiling change observed in Globorotalia acostaensis from sinestral (below) to dextral (above). This datum was already known in the Mediterranean. It has been recorded at the base of the Messinian from Crete, Sicily, and northern Algeria by Zachariasse (1975); in the "Tripoli" Formation immediately underlying the first evaporitic beds in Sicily (Stainforth et al., 1975); in the uppermost Miocene of southern Spain (Montenant et al., 1976); and a few meters beneath the basal evaporites in the Riba dello Zolfo section from Piedmont (Bossio et al., 1976). In equatorial Pacific piston cores, this same event has been recognized by Saito et al. (1975) as occurring at the base of paleomagnetic Epoch 5, exactly at the same position where it is recorded at Site 397 (i.e., between Sections 3 and 2 in Core 397 47). The coiling change also has been noticed in the Bou Regreg section (Bossio et al., 1976) where is postdates the FAD of $G$. conomiozea and predates the FAD of $G$. margaritae.

Relative to the Miocene/Pliocene boundary, a boundary stratotype recently has been designated at the base of the "Trubi" Formation at Cape Rossello, Sicily (Cita, 1975a). The boundary stratotype falls within the range of Globorotalia margaritae and of Amaurolithus tricorniculatus. It is near the FAD of Sphaeroidinella and prior to the FAD of Ceratolithus acutus; thus, it is in the latter part of Zone N.18, and in the earlier part of Zone NN 13 of Martini's (1971) standard nannofossil zonation. It postdates the LAD of Discoaster quinqueramus and lies close to the Gilbert/ Epoch 5 boundary of paleomagnetic stratigraphy. Taking into account all these correlation criteria, the best location of the Miocene/Pliocene boundary at Site 397 is within Core 397-42 (see also Mazzei et al., this volume).

\section{CORRELATION WITH OTHER MIOCENE SUCCESSIONS FROM THE CONTINENTAL MARGIN OF NORTHWEST AFRICA AND ADJACENT BASINS}

Table 1 indicates the location and water depth of twelve DSDP sites from the same general area (latitudinal range from $5^{\circ} \mathrm{N}$ to $35^{\circ} \mathrm{N}$; longitudinal range from $27^{\circ} \mathrm{W}$ to $10^{\circ} \mathrm{W}$ ) with which we established a correlation (see Figure 8). Figure 9 shows a more precise correlation, zone by zone, of the only three of the above sites with a continuous coring throughout the Neogene, i.e., DSDP Sites 397, 369, and 366. Site 369 is close to 397 , located on the continental slope off Cape Bojador; Site 366 is $21^{\circ}$ latitude to the south, on the Sierra Leone Rise, with water depth comparable to that at Site 397 (2853 and $2900 \mathrm{~m}$, respectively).

The biostratigraphic correlations indicated in Figure 9 permit a comparison which overcomes any difficulty resulting from the foraminiferal zonation followed in
TABLE 1

Coordinates and Water Depth of the DSDP Sites From the Eastern North Atlantic, Discussed in the Correlation With Site 397

\begin{tabular}{|c|c|c|c|c|}
\hline Leg & Site & $\begin{array}{l}\text { Latitude } \\
\text { (N) }\end{array}$ & $\begin{array}{l}\text { Longitude } \\
\text { (W) }\end{array}$ & $\begin{array}{l}\text { Water Depth } \\
\text { (m) }\end{array}$ \\
\hline 2 & $\begin{array}{c}12 \mathrm{C} \\
\text { (Cape Verde) }\end{array}$ & $19^{\circ} 41.73^{\prime}$ & $26^{\circ} 00.03^{\prime \prime}$ & 4557 \\
\hline 14 & 135 & $35^{\circ} 20.80^{\prime}$ & $10^{\circ} 25.46^{\prime \prime}$ & 4152 \\
\hline 14 & 136 & $34^{\circ} 10.13^{\prime}$ & $16^{\circ} 18.19^{\prime}$ & 4169 \\
\hline 14 & 137 & $25^{\circ} 55.53^{\prime}$ & $27^{\circ} 03.64^{\prime}$ & 5361 \\
\hline 14 & 138 & $25^{\circ} 55.37^{\prime}$ & $25^{\circ} 33.79^{\prime}$ & 5288 \\
\hline 14 & 139 & $23^{\circ} 31.14^{\prime}$ & $18^{\circ} 42.26^{\prime}$ & 3047 \\
\hline 14 & 140 & $21^{\circ} 44.97^{\prime}$ & $21^{\circ} 47.52^{\prime}$ & 4483 \\
\hline 41 & $\begin{array}{c}366 \\
\text { Sierra Leone }\end{array}$ & $5^{\circ} 40.7^{\prime}$ & $19^{\circ} 51.1^{\prime}$ & 2853 \\
\hline 41 & $\begin{array}{c}367 \\
\text { C. Verde Basin }\end{array}$ & $12^{\circ} 29.2^{\prime}$ & $20^{\circ} 02.8^{\prime}$ & 4748 \\
\hline 41 & $\begin{array}{c}368 \\
\text { C. Verde Rise }\end{array}$ & $17^{\circ} 30.4^{\prime}$ & $21^{\circ} 21.2^{\prime}$ & 3366 \\
\hline 41 & $\begin{array}{c}369 \\
\text { Spanish Sahara }\end{array}$ & $26^{\circ} 35.5^{\prime}$ & $14^{\circ} 59.9^{\prime}$ & 1752 \\
\hline 41 & $\begin{array}{c}370 \\
\text { Moroccan Basin }\end{array}$ & $32^{\circ} 50.2^{\prime}$ & $10^{\circ} 46.6^{\prime}$ & 4214 \\
\hline
\end{tabular}

Lancelot and Seibold (1977) which differs partly from that used here.

The Miocene succession cored on the slope (Site 369 ) is highly condensed and contains a number of stratigraphic gaps. The Sierra Leone Rise (Site 366) section is of special interest since it supports the assumption that the biostratigraphically documented gaps at Site 397 are not a local phenomenon related to a peculiar setting (inter-canyon base-of-slope), but a wideranging phenomenon. The approximately 170 -meterthick Miocene section of the Sierra Leone Rise displays two well-defined hiatuses: one near the base of Zone N.16, another one within Zone N.10, i.e., at exactly the same biostratigraphic horizons we recorded at Cape Bojador.

Though not yet fully understood, the wide extent of this middle Miocene (Serravallian) erosional phase(s) must be emphasized and further investigated.

The Miocene succession penetrated at Site 397 is the thickest and the most complete recovered to date from the eastern North Atlantic. Despite its upper continental rise setting and the occurrence of sediment types such as debris flows (in the lower Miocene) and volcaniclastic sandstones (in the middle Miocene), the biostratigraphic succession is relatively little disturbed and no major gaps are recorded within the Neogene. Consequently, we can consider the Cape Bojador section as a reference section for the eastern North Atlantic, with special regard to the upper Neogene.

\section{ACKNOWLEDGMENTS}

We acknowledge financial support from Consiglio Nazionale delle Richerche of Italy, Comitato 05, through Grants 76.00085 .05 to M. B. C. and 76.00137.05 to G. S.; and to Progetto Finalizzato GEODINAMICA, through Grant 77.00763.89 to M. B. C.

All the scanning electron photographs illustrating this paper were obtained by Mr. Agostino Rizzo, operating the instrument of CNR, Centra Alpi, Institute of Geology, University of Milano. 


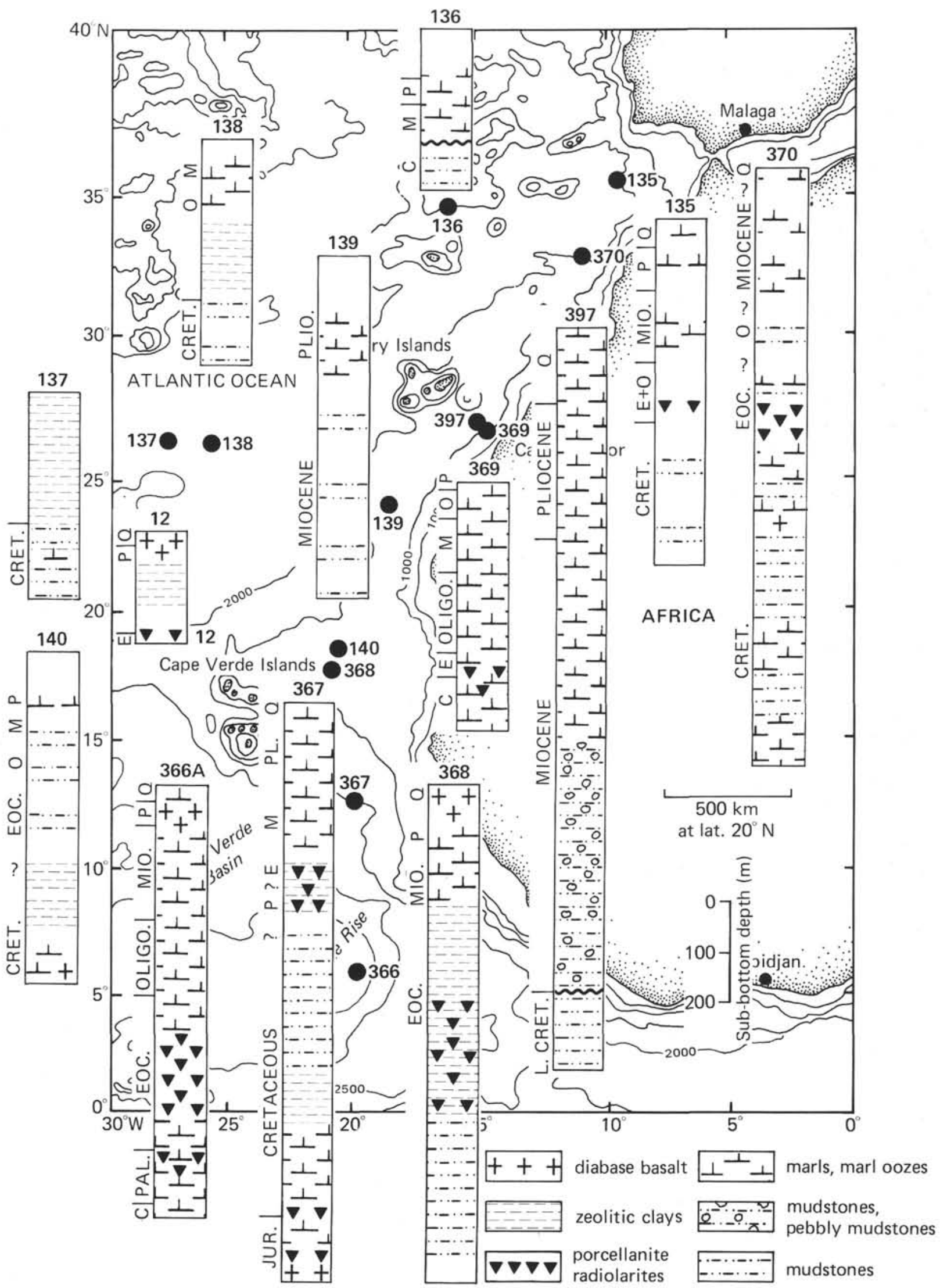

Figure 8. Stratigraphic columns of eastern North Atlantic DSDP Miocene sediments. 
397

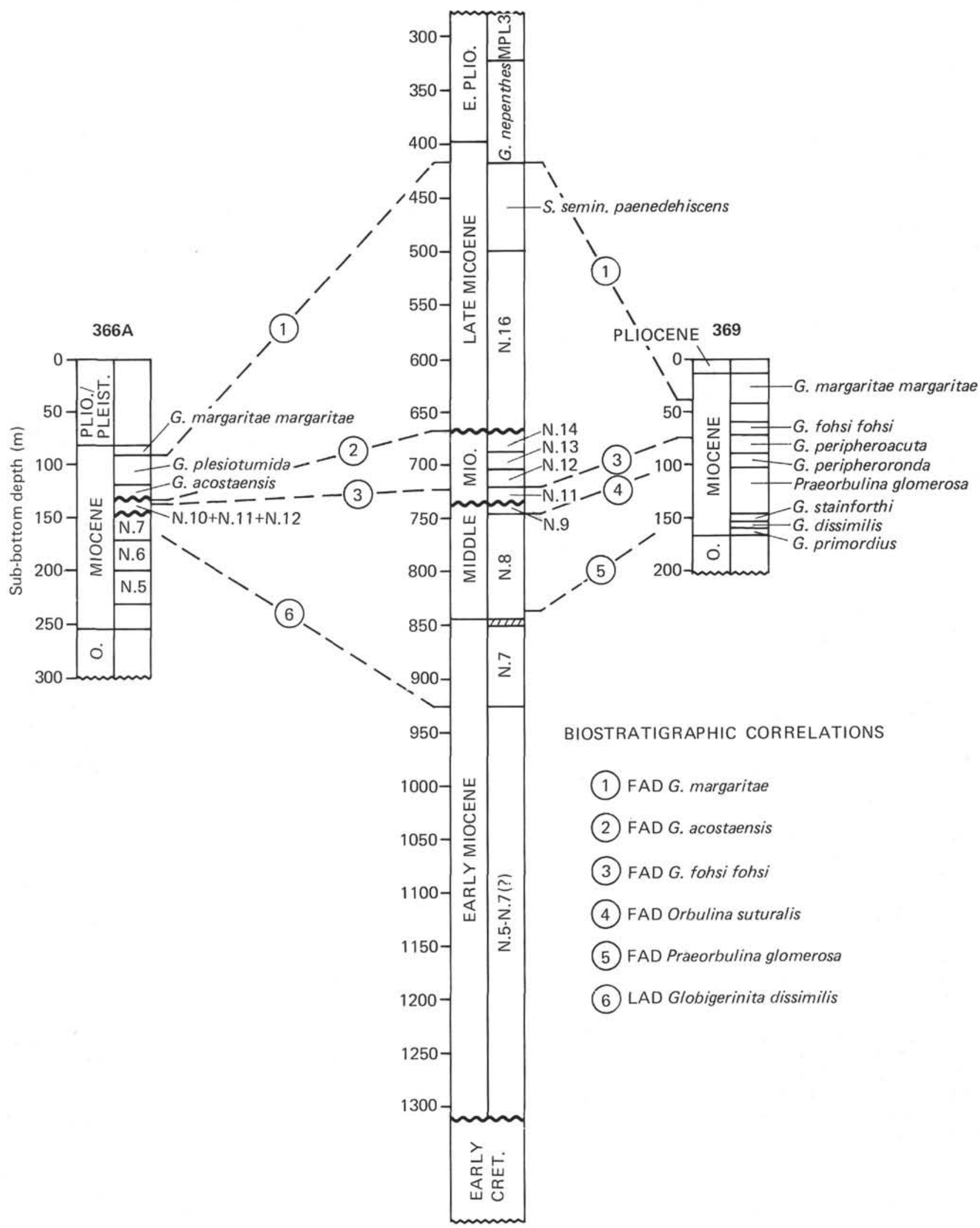

Figure 9. Biostratigraphic correlation of the Miocene successions penetrated at DSDP Sites 366 (Sierra Leone Rise), 397 (upper continental rise off Cape Bojador), and 369 (continental slope off Cape Bojador). 
Thanks are due to Mr. Giovanni Chiodi and Dr. Alessandro Bossio, for technical assistance.

The present manuscript has been critically read by $\mathrm{T}$. Saito, F. Proto Decima, W. B. F. Ryan, and R. B. Kidd.

This is contribution of IGCP Project Number 96 "Messinian Correlation."

\section{REFERENCES}

Banner, F. T. and Blow, W. H., 1960. Some primary types of species belonging to the Superfamily Globigerinaceae, Contrib. Cushman Found. Foram. Res., v. 11, p. 1-41. 1965. Progress in the planktonic foraminiferal biostratigraphy of the Neogene, Nature, v. 208, p. 1164-1166.

Beckman, J.-P., El Heiny, J., Kerdany, M. Y., Said, R., and Viotti, C., 1969. Standard planktonic zones of Egypt. Proc. First Intern. Conf. Plankt. Microfossils: Geneva, Leiden, (Brill), v. 1, p. 92-103.

Berggren, W. W. and Amdurer, M., 1973. Late Paleogene (Oligocene) and Neogene planktonic foraminiferal biostratigraphy of the Atlantic Ocean (Lat $30^{\circ} \mathrm{N}$ to Lat. $30^{\circ}$ S) Riv. Ital. Paleontol., v. 79, p. 337-391.

Berggren, W. A. and Haq, B. U., 1976. The Andalusian Stage (late Miocene); Biostratigraphy, biochronology and paleoecology, Palaeogeogr., Palaeoecol., Palaeoclimat., v. 20, p. $67-129$.

Bizon, G. and Bizon, J.-J., 1972. Atlas des principaux foraminiféres planctoniques du Bassin méditerranéen (Oligocène à Quaternaire): Paris, (Technip,), p. 1-316.

Blow, W. H., 1956. Origin and evolution of the foraminiferal genus Orbulina d'Orbigny, Micropaleontology, v. 2, p. 57 70.

1959. Age, correlation and biostratigraphy of the Upper Tocuyo (San Lorenzo) and Pozon formations, eastern Falcón, Venezuela, Am. Paleont. Bull. v. 39, p. 59251.

1969. Late Middle Eocene to Recent planktonic foraminiferal biostratigraphy, Proc. First Intern. Conf. Plankt. Microfossils: Geneva, (Leiden, Brill), v. 1, p. 192422.

Blow, W. H. and Banner, F. T., 1966. The morphology, taxonomy and biostratigraphy of Globorotalia barisanensis Le Roy, Globorotalia fohsi Cushman and Ellisor, and related taxa, Micropaleontology, v. 12, p. 286-302.

Bolli, H. M., 1950. The direction of coiling in the evolution of some Globorotaliidae, Cushman Found. Foram. Res. Contrib., v. 1, p. 82-89.

1957. Planktonic Foraminifera from the Oligocene-Miocene Cipero and Lengua formations of Trinidad, B. W. I., U.S. Nat. Museum Bull. 215, p. 97-123. , 1967. The subspecies of Globorotalia fohsi Cushman and Ellisor and the zones based on them, Micropaleoontology, v. 13, p. 502-512.

1970. The foraminifera of Sites 23-31, Leg 4. In Bader, R. G., Gerard, R. D., et al., Initial Reports of the Deep Sea Drilling Project, v. 4, Washington (U.S. Government Printing Office), p. 577-644.

Bolli, H. M. and Premoli Silva, I., 1973. Oligocene to Recent planktonic foraminifera and stratigraphy of the Leg 15 sites in the Caribbean Sea. In Edgar, N. T., Saunders, J. B., et al., Initial Reports of the Deep Sea Drilling Project, v. 15, Washington (U.S. Government Printing Office), p. 475-499.

Bossio, A., El-Bied Rakich, K., Giannelli, L., Mazzei, R., Russo, A., and Salvatorini, G., 1976. Corrélation de quelques sections stratigraphiques du Mio-Pliocène de la zone atlantique du Maroc avec les stratotypes du Bassin
Méditerranéen sur la base des Foraminifêres planctoniques, Nannoplancton calcaire et Ostracodes, Atti Soc. Tosc. Sc. Nat. Mem., v. 83, p. 121-137.

Brönnimann, P. and Resig, J., 1971. A Neogene globigerinacean biochronologic time-scale of the southwestern Pacific Initial Reports of the Deep Sea Drilling Project, v. 7, Part 2, Washington (U.S. Government Printing Office), p. 12351470.

Catalano, R. and Sprovieri, R., 1971. Biostratigrafia di alcune serie saheliane (Messiniano inferiore) in Sicilia, Proc. Second Plankt. Conf. Rome, 1970, v. 1, p. 211-250.

Cifelli, R. J., 1968. A note on the holotype of Globorotalia fohsi Cushman and Ellisor, Micropaleontology, v. 14, p. 369-370.

Cita, M. B., 1972. The Pliocene deep-sea record of the Mediterranean. I. Biostratigraphy and chronostratigraphy. In Ryan, W. B. F., Hsü, K. J., et al., Initial Reports of the Deep Sea Drilling Project, v. 13, Part 2: Washington (U.S. Government Printing Office), p. 1343-1379.

1975a. The Miocene/Pliocene boundary. History and definition. In Saito, T. and Burckle, L. (Eds.), Late neogene epoch boundaries: Micropaleontology Press, Spec. Publ., p. 1-24.

1975b. Planktonic foraminiferal biozonation of the Mediterranean Pliocene deep-sea record. A revision, Riv. Ital. Paleontol., v. 81, p. 527-544.

Cita, M. B. and Blow, W. H., 1969. The biostratigraphy of the Langhian, Serravallian and Tortonian stages in the type-sections in Italy, Riv., Ital. Paleontol., v. 75, p. 549603.

Cita, M. B., Decima, A., 1975. Rossellian: proposal of a superstage for the marine Pliocene. Proc. IV Congr. CMNS, Bratislava, 1975, t.1, p. 217-227.

Cita, M. B. and Gartner, S., 1973. The stratotype Zanclean; foraminiferal and nannofossil biostratigraphy, Riv. Ital. Paleontol., v. 79, p. 503-558.

Cita, M. B., Colalongo, M. L., D'Onofrio, S., Iaccarino, S. and Salvatorini, G., 1978. Biostratigraphy of Miocene deep sea sediments (Sites 372 and 375), with special reference to the Messinian/pre Messinian interval. In Hsü, K. J., Montadert, L., et al., Initial Reports of the Deep Sea Drilling Project, v. 42, Part 1: Washington (U.S. Government Printing Office), p. 671-686.

Colalongo, M. L. and Sartioni, S., 1967. Globorotalia hirsuta aemiliana, nuova sottospecie cronologica del Pliocene in Italia, Giorn. Geol., v. 34, p. 265-284.

DeMarcq, G., Magné, J., Anglada, R., and Carbonnel, G., 1974. Le Burdigalien stratotypique de la vallée du Rhône: sa position biostratigraphique, Bull. Soc. Géol. France, v. 16 , p. $509-515$.

D’Onofrio, S., 1964. I foraminiferi del neostratotipo del Messiniano, Giorn, Geol., v. 32, p. 113-228.

D'Onofrio, S., Giannelli, L., Iaccarino, S., Morlotti, E., Romeo, M., Salvatorini, G., Sampo', M., and Sprovieri, R., 1975. Planktonic foraminifera of the Upper Miocene from some Italian sections and the problem of the lower boundary of the Messinian, Boll. Soc. Paleontal. Ital., v. 14, p. 177-196.

Finlay, H. J., 1940. New Zealand Foraminifera: key species in stratigraphy. N. 4, Royal Soc. New Zealand Trans., v. 69 , p. $448-472$.

Hornibrook, N. de, 1958, New Zealand Upper Cretaceous and Tertiary foraminiferal zones and some overseas correlations, Micropaleontology, v. 4, p. 25-38.

Jenkins, D. G., 1966. Planktonic Foraminifera from the type Aquitanian-Burdigalian of France, Cushman Found. Foram. Res. Contr., v. 17, p. 1-15. 
1971. New Zealand Cenozoic planktonic Foraminifera, New Zealand Geol. Survey Paleontol. Bull., no. 42.

Lancelot, Y. and Seibold, E., et al, 1978. Initial Reports of the Deep Sea Drilling Project, v. 41: Washington (U.S. Government Printing Office),

Martini, E., 1971. Standard Teriary and Quaternary calcareous nannoplankton zonation, Proc. Second Planktonic Conference, Roma, 1970, v. 1, p. 739-785.

Montenat, C., Bizon, G., and Bizon, J.-J., 1976. Continuité ou discontinuité de sédimentation marine Mio-Pliocène en Méditerranée ocidentale. L'exemple du Bassin de Vera (Espagne Méridionale), Rev. Inst. Franc. Petrole, v. 31, p. 613-663.

Natori, H., 1976. Planktonic foraminiferal biostratigraphy and datum planes in the Late Cenozoic sedimentary sequence in Okinawa-jima, Japan. In Tayanagi, Y. and Saito, T. (Eds.), Progress in micropaleontology, Micropaleontology Press, Spec. Publ. 2, p. 214-243.

Olsson, R. K., 1972. Growth changes in the Globorotalia fohsi, lineage, Eclogae Geol. Helv., v. 65, p.165-184.

Parker, F. L., 1967. Late Tertiary biostratigraphy (planktonic foraminifera) of tropical Indo-Pacific deep-sea cores, $\mathrm{Am}$. Paleontol. Bull., v. 52, p. 115-203.

1973. Late Cenozoic biostratigraphy (planktonic foraminifera) of tropical Atlantic deep-sea sections, Rev. Espanola Micropal., v. 5, p. 253-289.

Renz, H. H., 1948. Stratigraphy and fauna of the Agua Salada Group, State of Falcon, Venezuela, Geol. Soc. Am. Mem. 32.

Ruggieri, G., 1967. The Miocene and Later Evolution of the Mediterranean Sea. In Adams, C. G. and Ager, D. V. (Eds.), Aspects of tethyan biogeography: Systematics Assoc, Publ. 7, p. 283-290.

Ryan, W. B. F., Cita, M. B., Dreyfus Rawson, M., Burckle, L. H., and Saito, T., 1974. A paleomagnetic assignment of
Neogene stage boundaries and the development of isochronous datum planes between the Mediterranean, the $\mathrm{Pa}$ cific and Indian Oceans in order to investigate the response of the world ocean to the Mediterranean "salinity crisis," Riv. Ital. Paleontol., v. 80, p. 631-688.

Saito, T., Burckle, L. H., and Hays, J. D., 1975. Late Miocene to Pleistocene biostratigraphy of equatorial Pacific sediments. In Saito T. and Burckle, L. H. (Eds.), Late Neogene epoch boundaries, Micropaleontology Press, Spec. Publ. 1 , p. 226-244.

Selli, R., 1960. Il Messiniano Mayer-Eymar 1867; proposta di un neostratotipo, Giorn. Geol., v. 28, p. 1-33.

Srinivasan, M. S. and Kennett, J. P., 1976. Evolution and phenotypic variation in the Late Cenozoic Neogloboquadrina dutertrei plexus. In Takayanagi, Y. and Saito, T. (Eds.), Progress in micropaleontology, Micropaleontology Press, Spec. Publ. 2, p. 329-355.

Stainforth, R. M., Lamb, J. L., Luterbacher, H. P., Beard, J. H., and Jeffords, R. M., 1975. Cenozoic planktonic foraminiferal zonation and characteristic index forms, The Univ. Kansas Paleontol. Contrib, Article 60, p. 1-425.

Walters, R., 1965. The Globorotalia zealandica and G. miozea lineages, New Zealand J. Geol. Geophys., v. 8, p. 109127.

Wernli, R., 1977. Les foraminiferes planctoniques de la limite Mio-Pliocène dans les environ de Rabat (Maroc), Eclogae Geol. Helv., v. 70, p. 143-191.

Zachariasse, W. J., 1975. Planktonic foraminiferal biostratigraphy of the Late Neogene of Crete (Greece), Utrecht Micropal. Bull. 11.

Zocchi, M., 1974. Variabilita di Globorotalia margaritae Bolli and Bermudez nel Pliocene inferiore tirrenico, Riv. Ital. Paleontol., v. 80, p. 101-145. 


\section{PLATE 1}

Figures 1, 2, 4 Globigerina venezuelana Hedberg.

1. Umbilical view, $\times 100$. Sample 397-41-6, 25-27 cm. Globigerina nepenthes Zone, Zanclean.

2. Umbilical view, $\times 100$.

4. Spiral view, $\times 100$. Sample 397-70-3, 49-52 cm. Zone N.16, Tortonian.

Figures 3, 6 Globigerina calida praecalida Blow.

Umbilical views, $\times 100$.

Sample 397-33-4, 49-52 cm. Zone M Pl 3, Zanclean.

Figure $5 \quad$ Globigerina praebulloides Blow.

Umbilical view, $\times 100$.

Sample 397-94-1,22-24 cm. Zone N.7, Burdigalian.

Figures 7, 8 Globigerina digitata praedigitata Parker.

7. Umbilical view, $\times 100$.

8. Spiral view, $\times 100$. Sample 397-34-3-50-53 cm. Zone M Pl 3, Zanclean.

Figures 9, 13, Globigerina drury Akers. 14

9. Umbilical view, $\times 100$. Sample 397-94-1, 22-24 cm. Zone N.7, Burdigalian.

13. Spiral view, $\times 100$.

Sample 397-97-1, 40-43 cm. Zone N.7, Burdigalian.

14. Umbilical view, $\times 100$.

Sample 397-76, CC. Zone N.11, Serravallian.

Figures 10, 15 Globigerina apertura Cushman.

10. Umbilical view, $\times 100$.

15. Spiral view, $\times 100$. Sample 397-34-5, 50-53 cm. Zone M Pl 3, Zanclean

Figures 11, 12 Globigerina decoraperta Takayanagi and Saito. Umbilical views, $\times 100$.

Sample 397-34-1, 50-53 cm. Zone M Pl 3, Zanclean.

Figures 16-18 Globigerina regina Crescenti.

16,18 . Umbilical views, $\times 100$.

17. Spiral view, $\times 100$.

Sample $397-66-4,53-57 \mathrm{~cm}$. Zone N.16, Tortonian.

Figure 19 Globigerina nepenthes Todd.

Umbilical view, $\times 100$.

Sample 397-66-4, 53-57 cm. Zone N.16,

Tortonian. 
PLATE 1
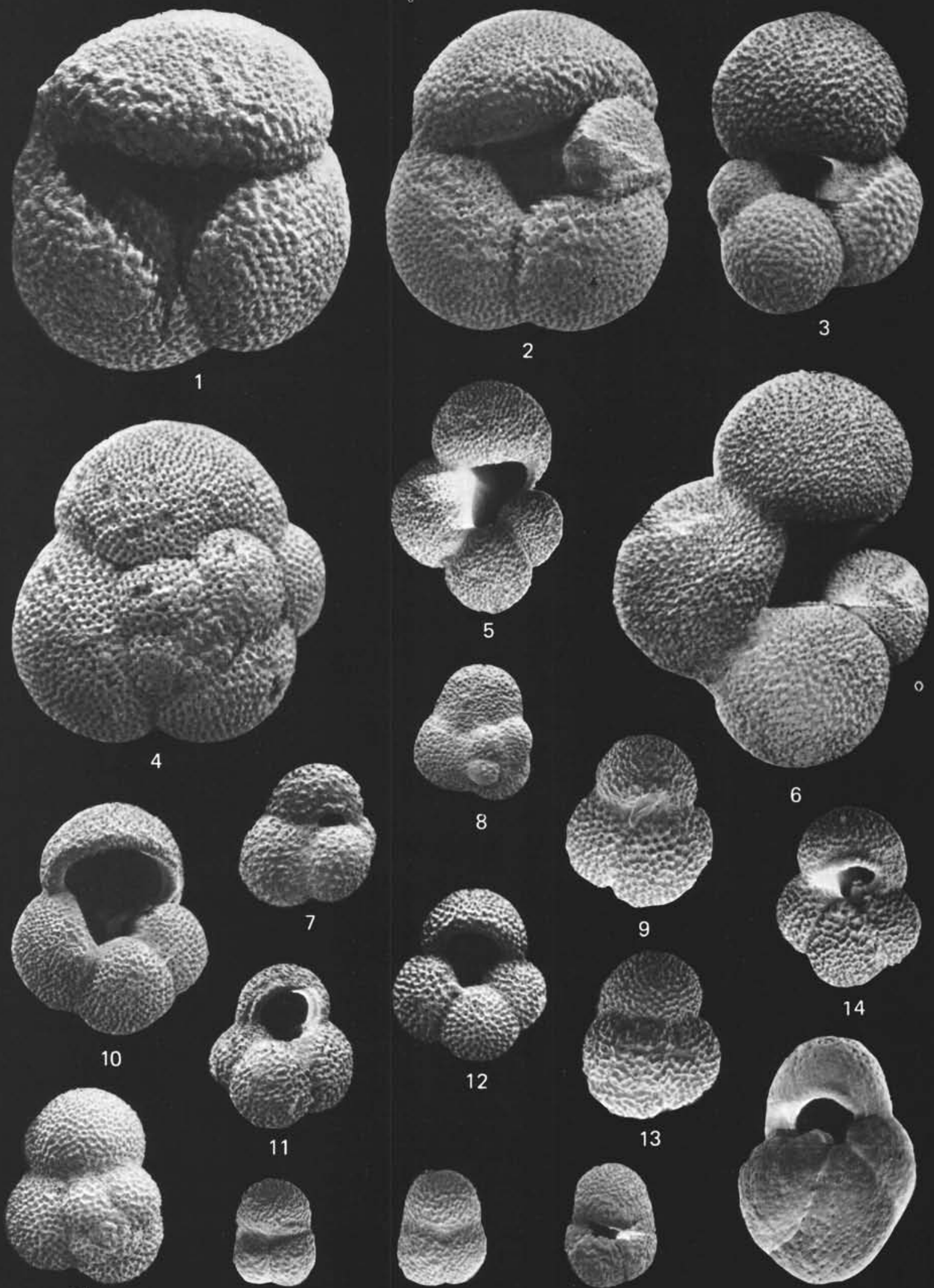

15

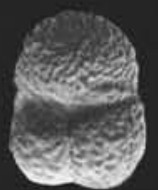

16

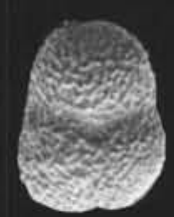

17
12

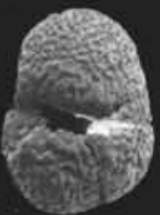

18

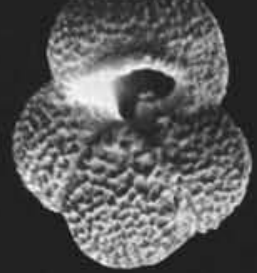

14

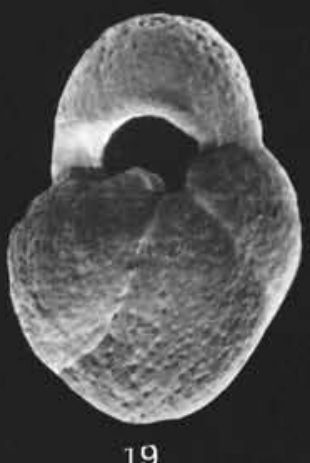

19 


\section{PLATE 2}

Figures 1, 2 Globigerina nepenthes Todd.

1. Umbilical view, $\times 100$. Sample $397-55-1,50-52 \mathrm{~cm}$. Zone N.16, Tortonian.

2. Umbilical view, $\times 100$. Sample $397-50-1,57-59 \mathrm{~cm}$. Sphaeroidinellopsis seminulina paenedehiscens Zone, Tortonian.

Figure $3 \quad$ Globigerina bulloides d'Orbigny.

Umbilical view, $\times 100$. Sample $397-36-2,50-53 \mathrm{~cm}$. Globigerina nepenthes Zone, Zanclean.

Figures 4, 10 Globigerina parabulloides Blow.

Umbilical views, $\times 100$. Sample 397-63, CC. Zone N.16, Tortonian.

Figures 5, 6 Hastigerina prolixa (Lipps). Two views of the same specimen.

5. Equatorial view, $\times 100$.

6. Umbilical view, $\times 100$. Sample 397-85, CC. Zone N.8, Langhian.

Figures 7-9 Globigerina eamesi Blow.

7. Spiral view, $\times 100$.

9. Umbilical view, $\times 100$. Sample $397-69-4,50-53 \mathrm{~cm}$. Zone N.16, Tortonian.

8. Umbilical view, $\times 100$. Sample $397-69-1,60-62 \mathrm{~cm}$. Zone N.16, Tortonian.

Figures 11, 12 Globigerina aff. ouachitaensis ciperoensis Bolli.

11. Umbilical view, $\times 100$. Sample $397-92-1,34-37 \mathrm{~cm}$. Zone N.7, Burdigalian.

12. Spiral view, $\times 100$. Sample $397-94-1,22-24 \mathrm{~cm}$. Zone N.7, Burdigalian.

Figures 13, 14 Globigerina foliata Bolli.

13. Umbilical view, $\times 100$.

14. Spiral view, $\times 100$. Sample 397-69-1, 60-62 cm. Zone N.16, Tortonian.

Figure $15 \quad$ Globigerina falconensis Blow.

Umbilical view, $\times 100$. Sample 397-34-1, 50-53 cm. Zone M Pl 3, Zanclean.

Figure $16 \quad$ Globigerinatella insueta Cushman and Stainforth.

Umbilical view, $\times 100$. Sample 397-85, CC. Zone N.8, Langhian.

Figures 17-20 Turborotalita sp.

17. Umbilical view, $\times 100$. Sample $397-55-3,49-52 \mathrm{~cm}$. Zone N.16, Tortonian.

18. Side view, $\times 100$. Sample 397-63-1, 52-55 cm. Zone N.16, Tortonian.

19. Umbilical view, $\times 100$. Sample $397-60-6,30-32 \mathrm{~cm}$. Zone N.16, Tortonian.

20. Spiral view, $\times 100$. Sample 397-61-4, 65-67 cm. Zone N.16, Tortonian.

Figures 21, 22 Hastigerina siphonifera siphonifera (d'Orbigny).

21. Umbilical view, $\times 100$.

22. Equatorial view, $\times 100$. Sample $397-39-2,50-52 \mathrm{~cm}$. Globigerina nepenthes Zone, Zanclean.

Figures 23, 24 Hastigerina siphonifera praesiphonifera Blow.

23. Umbilical view, $\times 100$. Sample $397-90-2,90-93 \mathrm{~cm}$. Zone N.7, Burdigalian.

24. Equatorial view, $\times 100$. Sample $397-84,10-14 \mathrm{~cm}$. Zone N.8, Langhian. 


\section{PLATE 2}
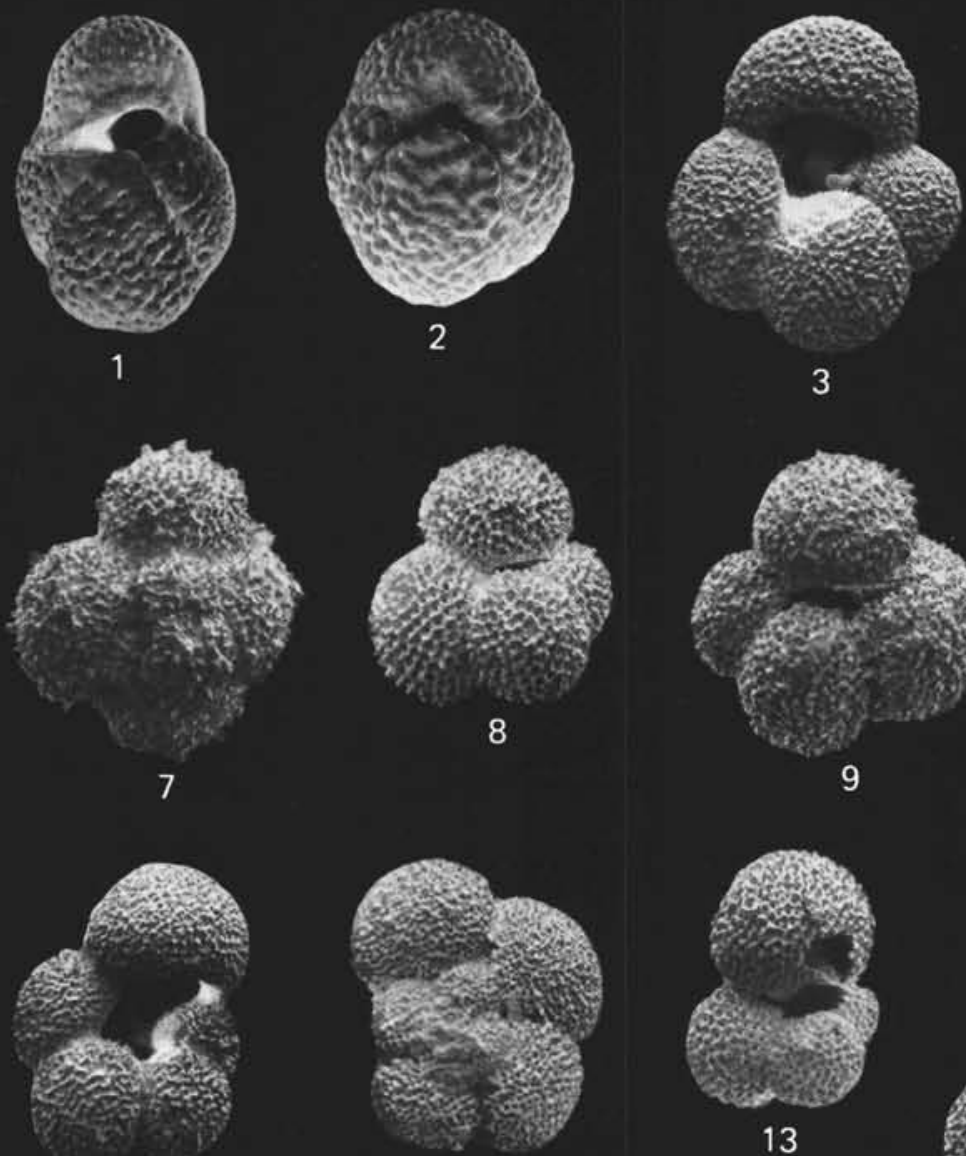

11

12

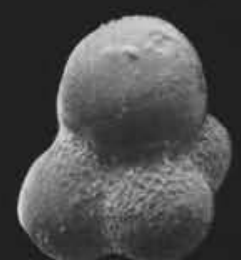

17
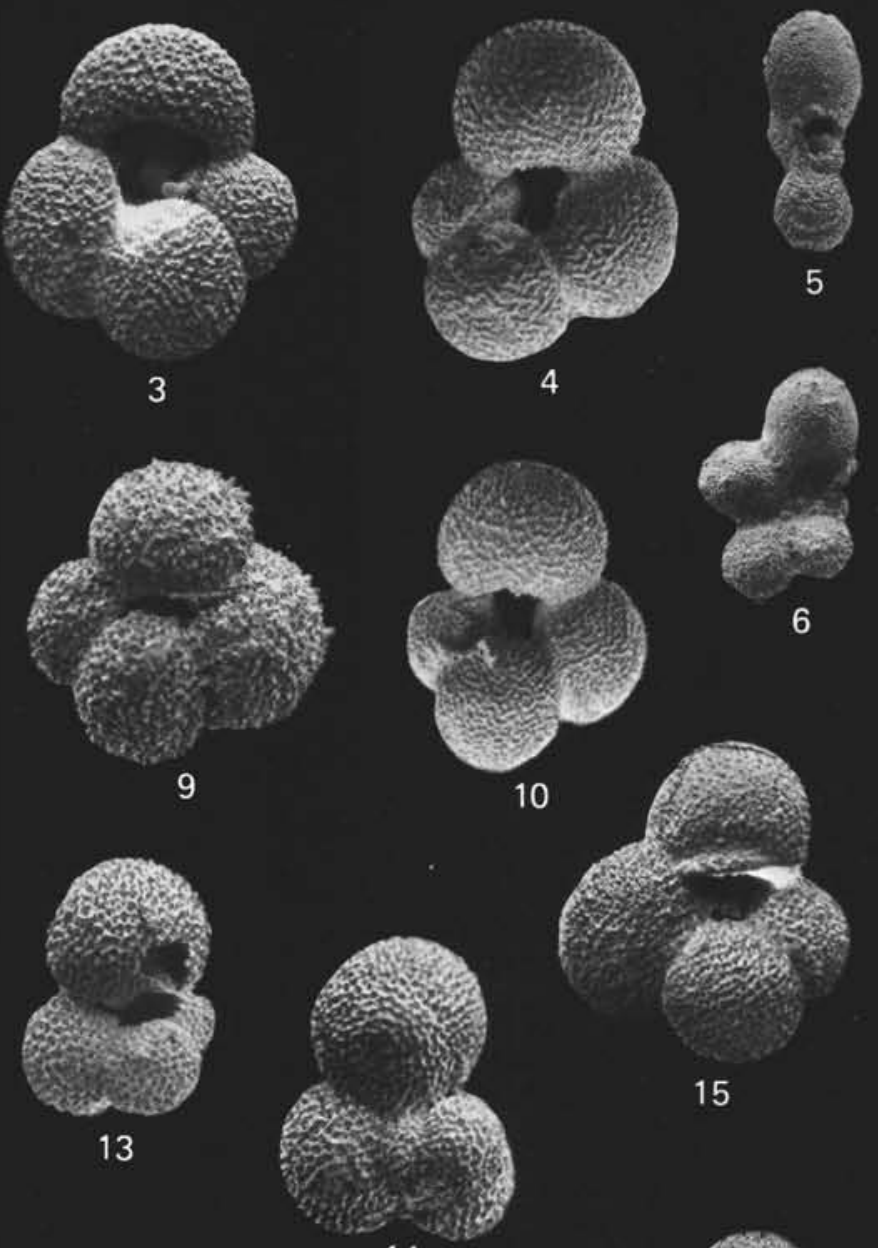

6
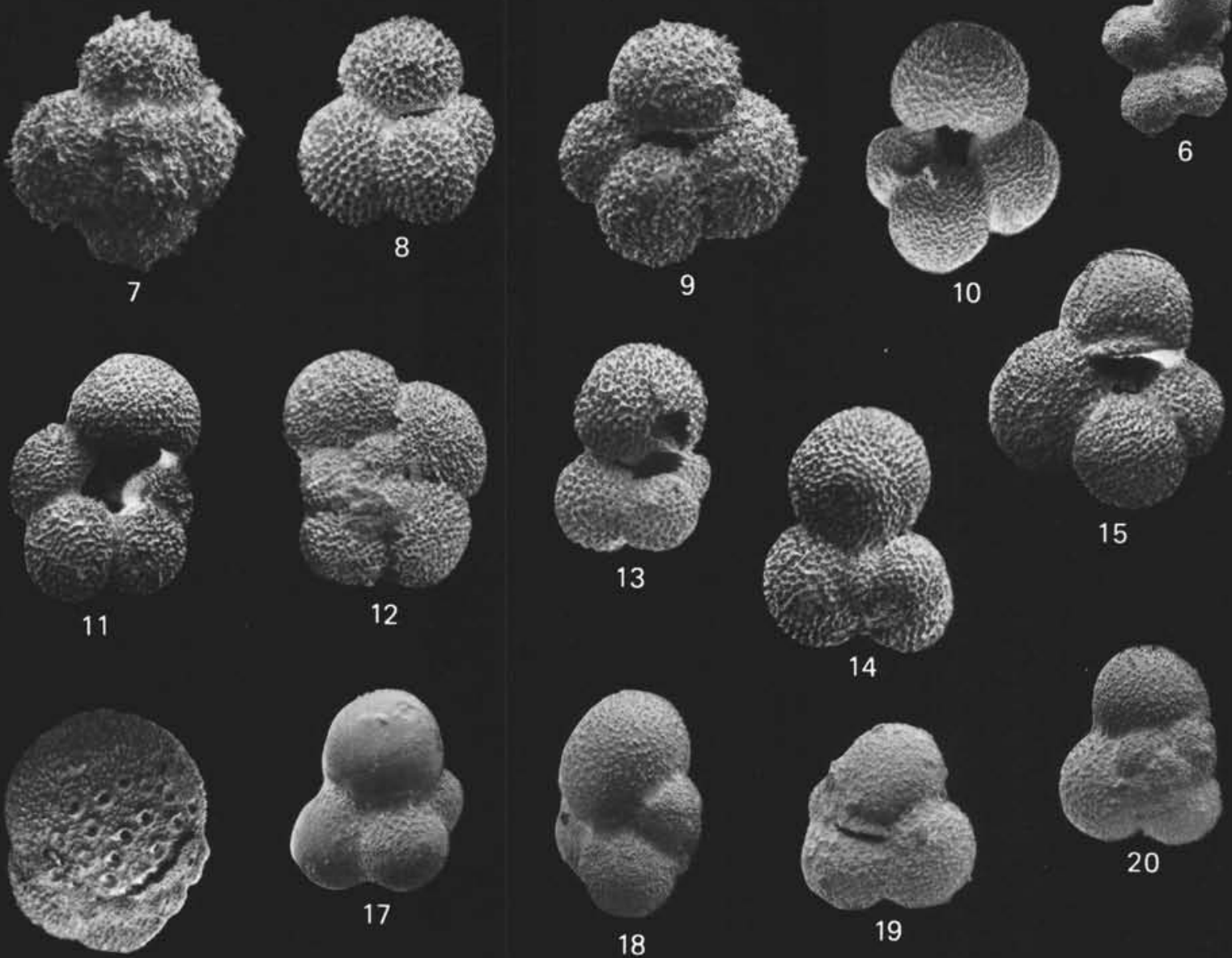

18
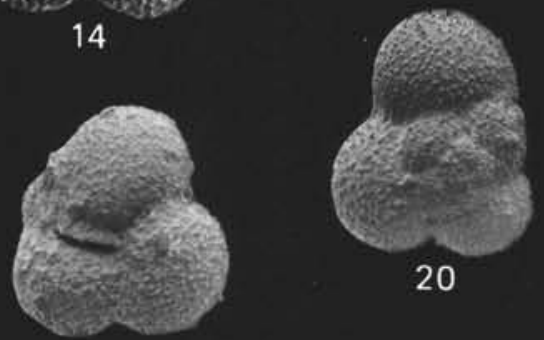

19

16

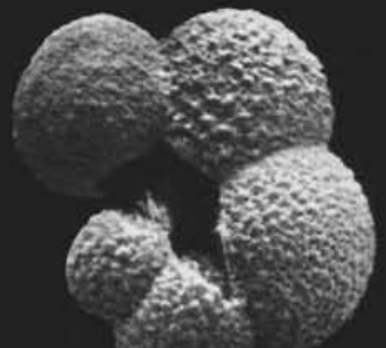

21

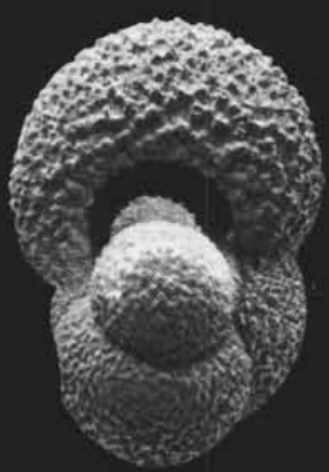

22

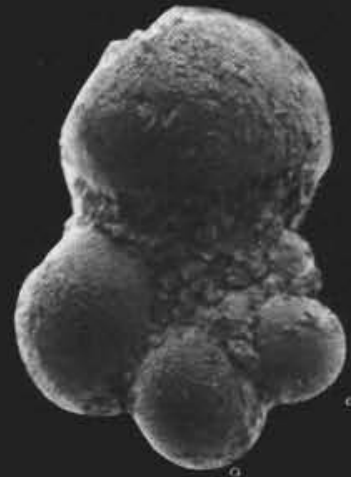

23

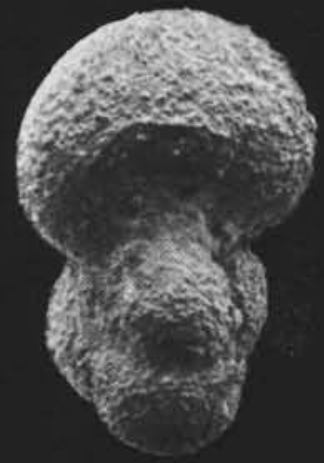

24 


\section{PLATE 3}

Figures 1-3 Globigerinopsis aguasayensis Bolli.

1. Umbilical view, $\times 100$. Sample $397-76-1,95-97 \mathrm{~cm}$. Zone N.11, Serravallian.

2. Side oblique view, $\times 100$.

3. Spiral view, $\times 100$. Sample $397-57$, CC. Slump within Zone N.16.

Figures 4, 5 Globoquadrina larmeui larmeui Akers.

4. Umbilical view, $\times 100$.

5. Spiral view, $\times 100$. Sample $397-92$, CC. Zone N.7, Burdigalian.

Figures 6-8 Globorotalia bermudezi (Bolli).

Three views of the same specimen:

6. Umbilical view, $\times 100$.

7. Spiral view, $\times 100$.

8. Side view, $\times 100$.

Sample $397-61-4,135-137 \mathrm{~cm}$. Slump within Zone N.16.

Figure 9 Globoquadrina langhiana Cita and Gelati.

Umbilical view, $\times 100$. Sample 397-97, CC. Zone N.7, Burdigalian.

Figures 10, 14 Globoquadrina altispira altispira (Cushman and Jarvis).

10. Umbilical view, $\times 100$.

14. Side view, $\times 100$. Sample $397-47-3,50-52 \mathrm{~cm}$. Sphaeroidinellopsis seminulina paenedehiscens Zone, Messinian.

Figure 11 Globoquadrina dehiscens dehiscens (Chapman, Parr, and Collins). Umbilical view, $\times 100$.

Sample 397-83-1, 41-43 cm. Zone N.8, Langhian.

Figure 12 Candeina nitida praenitida Blow.

Spiral oblique view showing the antepenultimate intercameral suture (pointed out by the arrows), without supplementary apertures, $\times 100$. Sample $397-56-1,51-53 \mathrm{~cm}$. Zone N.16, Tortonian.

Figure 13 Candeina nitida nitida d'Orbigny.

Spiral oblique view showing the antepenultimate intercameral suture (pointed out by the arrows), with supplementary apertures, $\times 100$. Sample 397-39-2, 50-52 cm. Globigerina nepenthes Zone, Zanclean.

Figure 15 Globoquadrina baromoenensis (Le Roy).

Umbilical view, $\times 100$. Sample $397-72-1,51-53 \mathrm{~cm}$. Zone N.14, Serravallian.

Figure 16 Globoquadrina altispira globosa Bolli.

Umbilical view, $\times 100$. Sample 397-68-1, 50-52 cm. Zone N.16, Tortonian. 


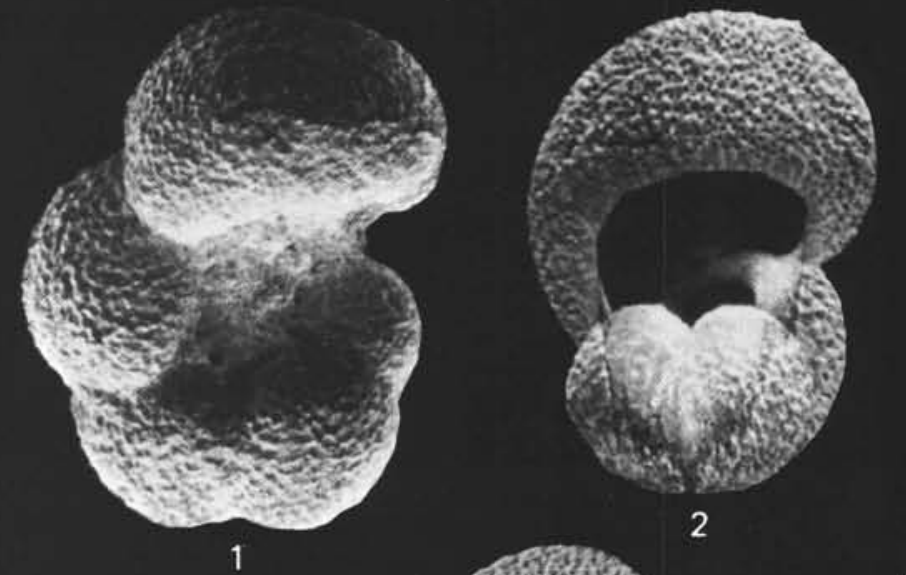

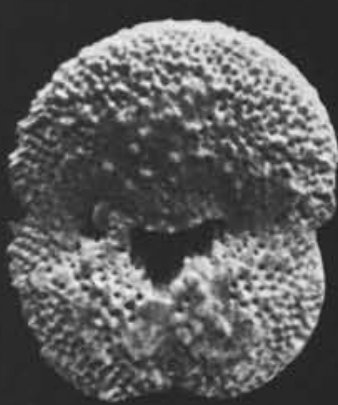

4

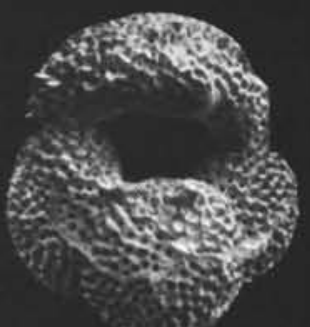

9

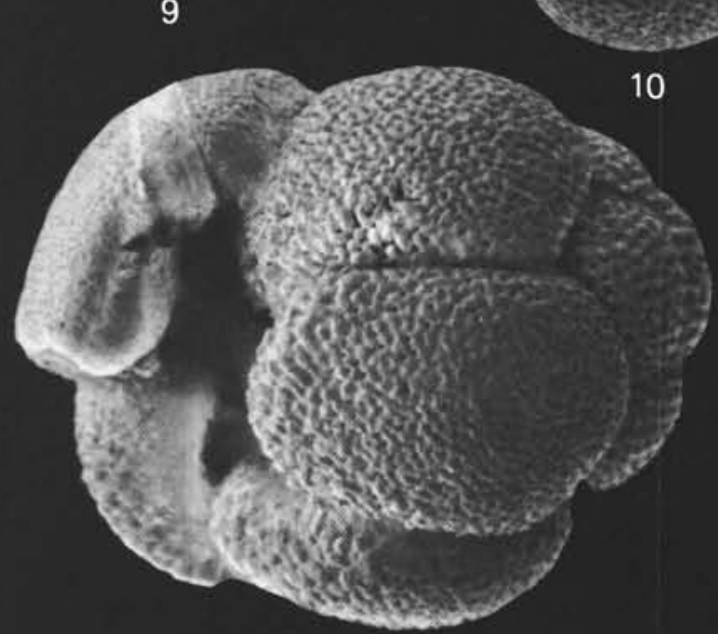

14
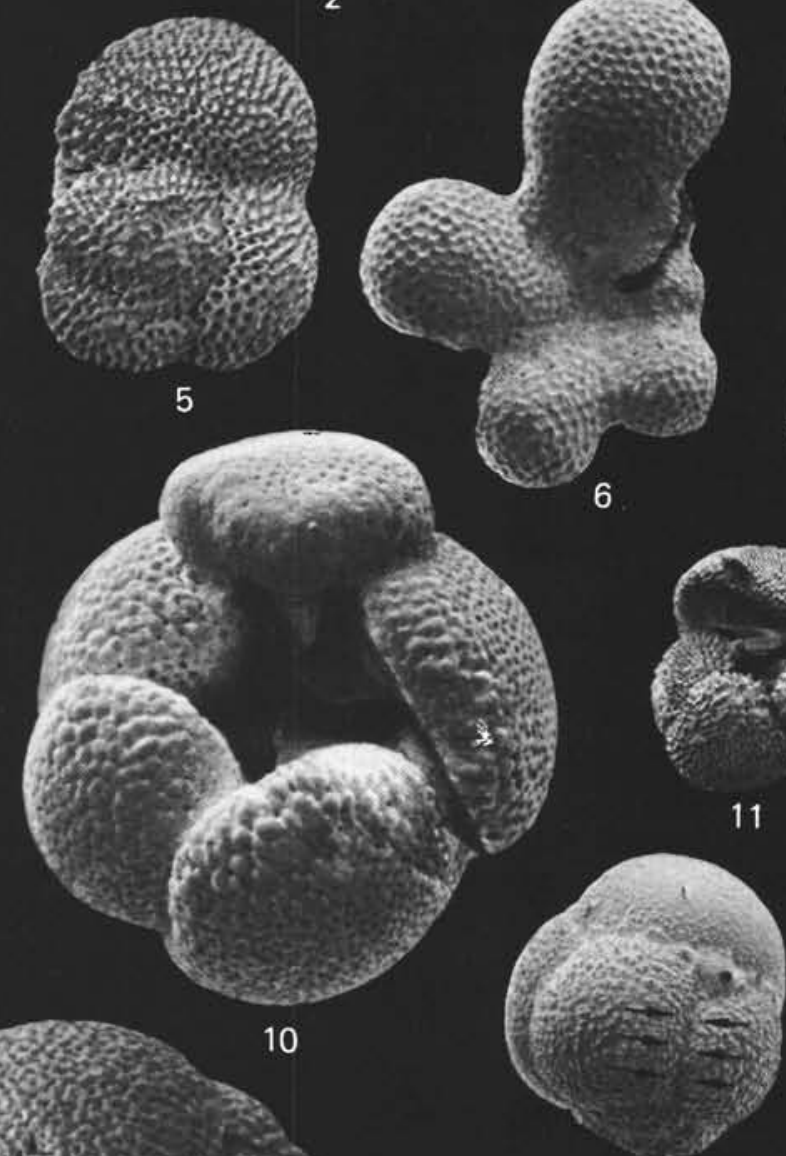

12

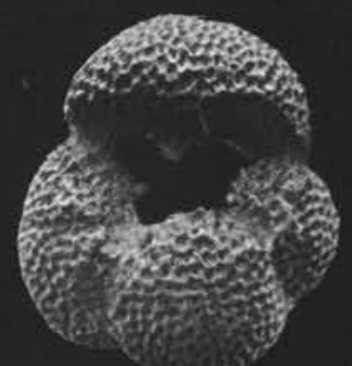

15

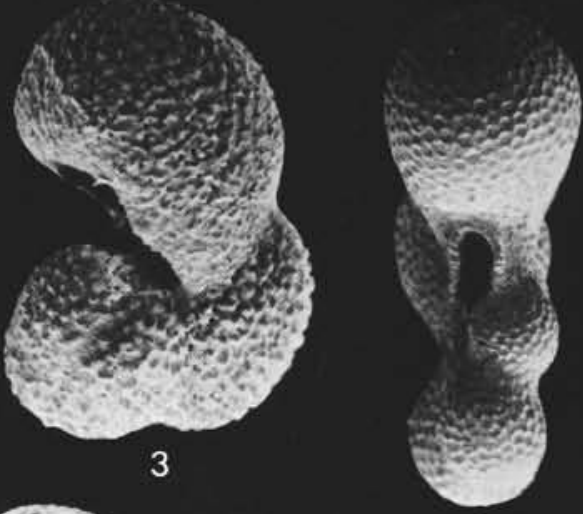

8 


\section{PLATE 4}

Figures 1-4 Globorotaloides sp.

1,2 . Umbilical views, $\times 100$.

3. Side view, $\times 100$.

4. Spiral view, $\times 100$.

Sample 397-55-3, $49-52 \mathrm{~cm}$. Zone N.16, Tortonian.

Figures 5-7 Globorotaloides falconarae Gioannelli and Salvatorini.

5, 6. Umbilical views, $\times 100$.

7. Spiral view $\times 100$.

Sample 397-63-1, 52-55 cm. Zone N.16, Tortonian.

Figures 8, $9 \quad$ Globorotaloides hexagona s.l.

Umbilical views, $\times 100$.

Sample 397-34-3, 50-53 cm. Zone M PI 3, Zanclean.

Figures 10-12 Pulleniatina primalis Banner and Blow.

10. Umbilical view, $\times 100$.

Sample 397-34-2, 50-53 cm. Zone M Pl 3. Zanclean.

11. Spiral view, $\times 100$.

12. Side view, $\times 100$.

Sample 397-34-1, 50-52 cm. Zone M Pl 3

Zanclean.

Figures 13-17 Sphaeroidinellopsis disjuncta (Finlay).

13,17 . Umbilical view, $\times 100$.

Sample 397-92, CC.

14,16 . Umbilical views, $\times 100$.

15. Detail of Figure $14, \times 250$.

Sample of 397-90, CC. Zone N.7, Burdigalian.

Figures 18-20 Sphaeroidinellopsis subdehiscens (Blow).

Umbilical views, $\times 100$.

Sample 397-65-4, 50-52 cm. Zone N.16, Tortonian.

Figure $21 \quad$ Cassigerinella chipolensis (Cushman and Ponton).

Umbilical view, $\times 150$.

Sample 397-94-1, 22-24 cm. Zone N.7,

Burdigalian. 


\section{PLATE 4}
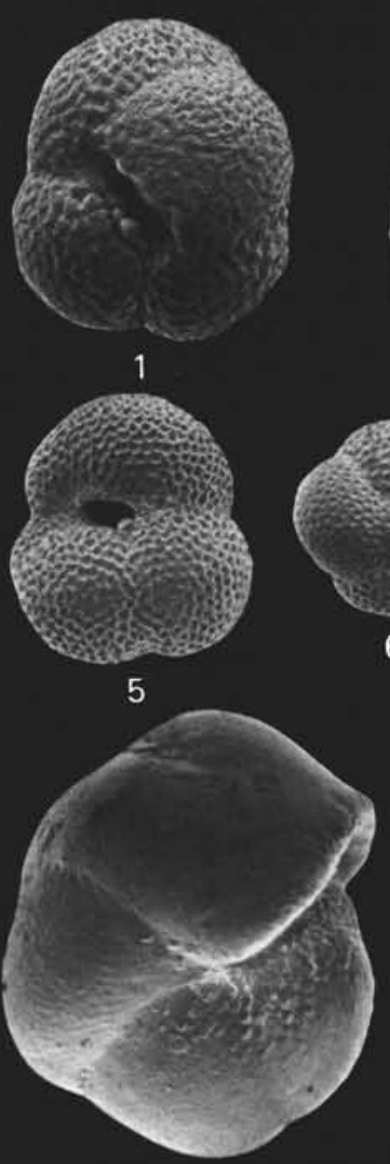

10

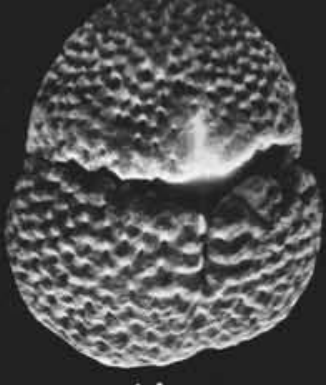

14

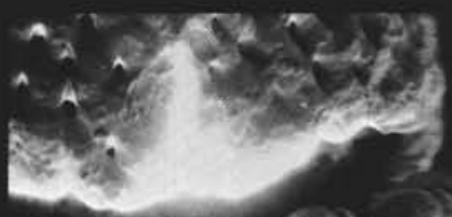

and

15
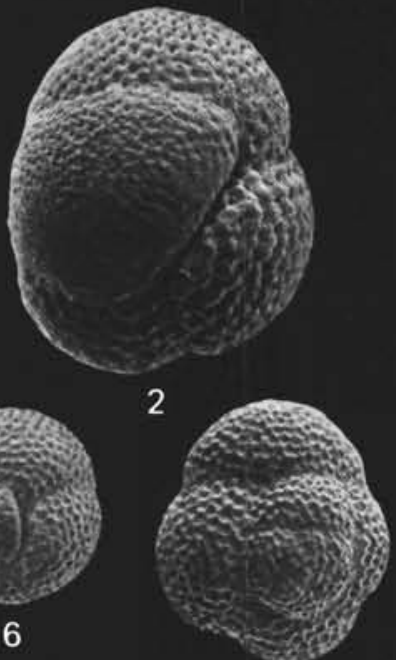

6

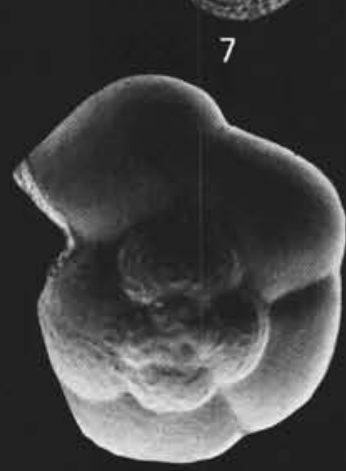

11

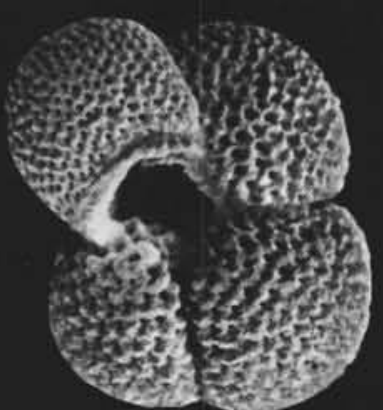

16

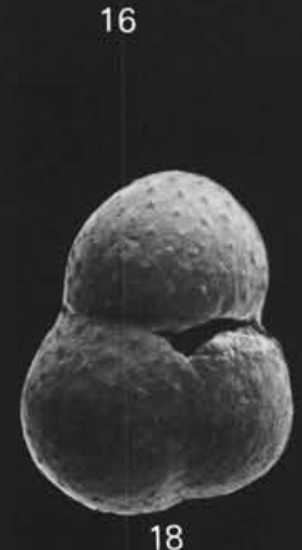

18

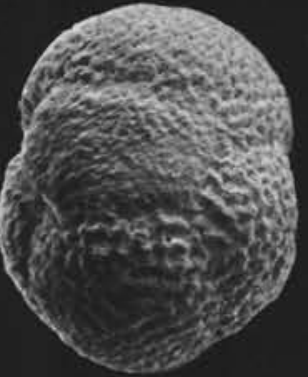

3

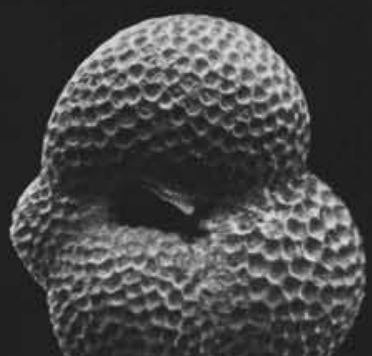

8

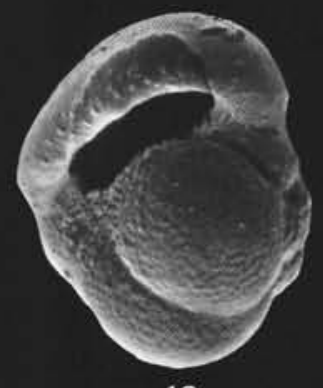

12

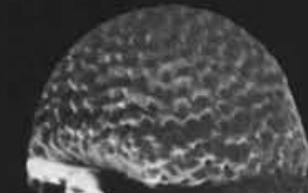
ats A ${ }^{2}=$
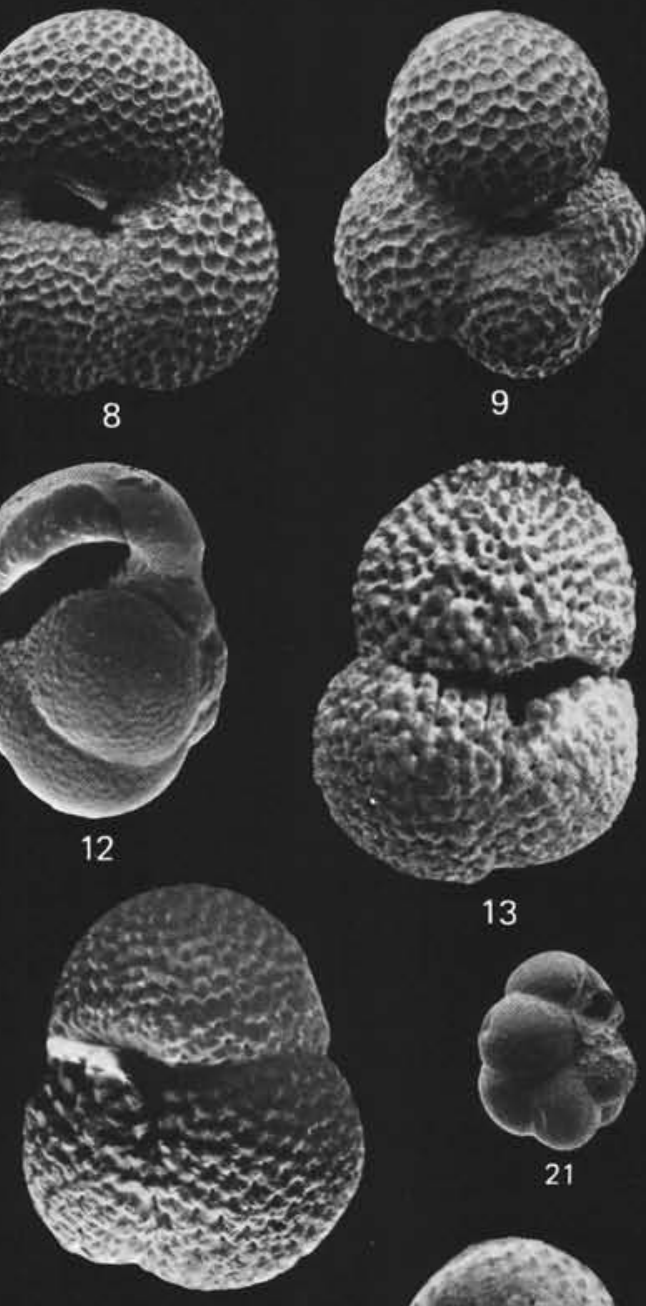

13
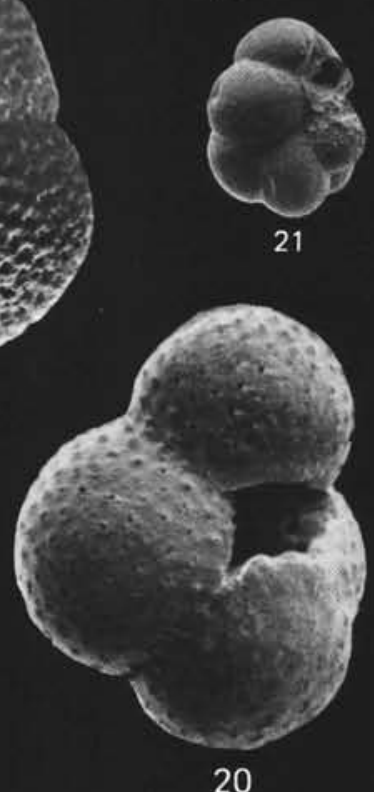


\section{PLATE 5}

Figures 1, 2, 4 Sphaeroidinellopsis seminulina seminulina (Schwager).

1,4. Umbilical views, $\times 100$. Sample 397-39-2 50-51 cm. Globigerina nepenthes Zone, Zanclean.

2. Umbilical view, $\times 100$. Sample 397-55-3, 49-52 cm. Zone N.16, Tortonian.

Figures 3, 5-11 Sphaeroidinellopsis seminulina paenedehiscens Blow.

$3,7,8$. Umbilical views, $\times 100$.

5. Spiral view, $\times 100$. Sample 397-41-3, 50-53 $\mathrm{cm}$. Globigerina nepenthes Zone, Zanclean.

6. Umbilical view, $\times 100$. Sample 397-37-4, 45-48 cm. Globigerina nepenthes Zone, Zanclean.

9,11 . Umbilical views, $\times 100$.

10. Details of Figure $11, \times 250$.

Sample 397-34-1, 50-53 cm. Zone M Pl 3, Zanclean.

Figure 12 Sphaeroidinella dehiscens dehiscens forma immatura (Cushman).

Spiral view, $\times 100$.

Sample 397-34-3, 50-53 cm. Zone M Pl 3, Zanclean. 


\section{PLATE 5}
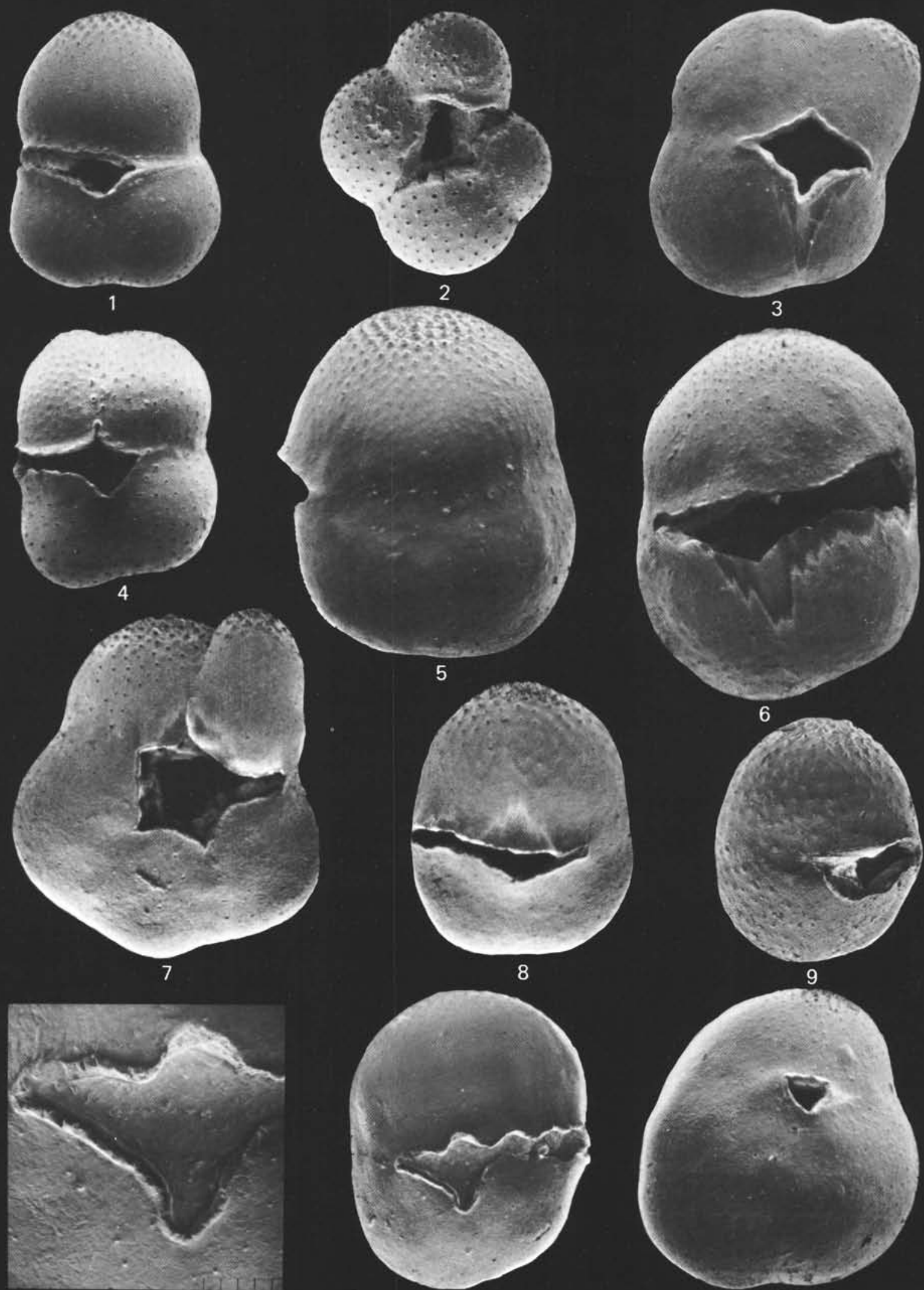

10
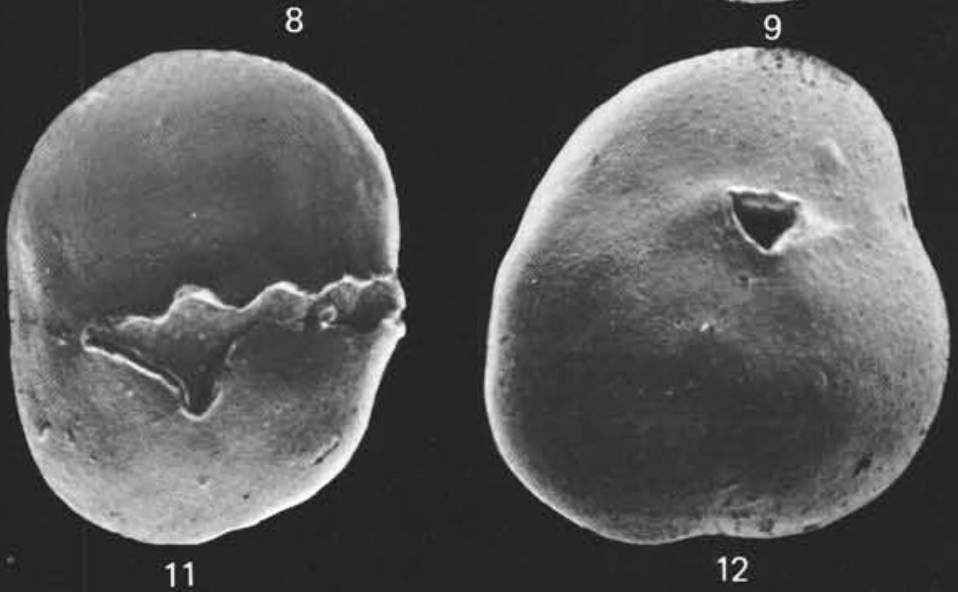


\section{PLATE 6}

Figures 1, $4 \quad$ Praeorbulina transitoria (Blow).

Spiral views, $\times 100$.

Sample 397-84, 10-14 cm. Zone N.8, Langhian.

Figures 2, 3, 5 Praeorbulina glomerosa curva (Blow).

2. Spiral oblique view, $\times 100$.

3,5 . Side views, $\times 100$.

Sample $397-84-4,10-14 \mathrm{~cm}$. Zone N.8, Langhian.

Figures 6, 7, 9 Praeorbulina glomerosa glomerosa (Blow).

6. Spiral view, $\times 100$.

Sample $397-78-3,74-78 \mathrm{~cm}$. Zone N.8, Langhian.

7. Side view, $\times 100$.

Sample 397-80-1, 134-135 cm. Zone N.8, Langhian.

9. Side view, $\times 100$.

Sample $397-84-4,10-14 \mathrm{~cm}$. Zone N.8, Langhian.

Figure $10 \quad$ Praeorbulina glomerosa circularis (Blow).

Side view, $\times 100$.

Sample 397-78-2, 34-36 cm. Zone N.9, Langhian.

Figures 8, 11 Globigerinoides sicanus De Stefani.

Umbilical views, $\times 100$.

Sample 397-84-4, 10-14 cm. Zone N.8, Langhian. 


\section{PLATE 6}
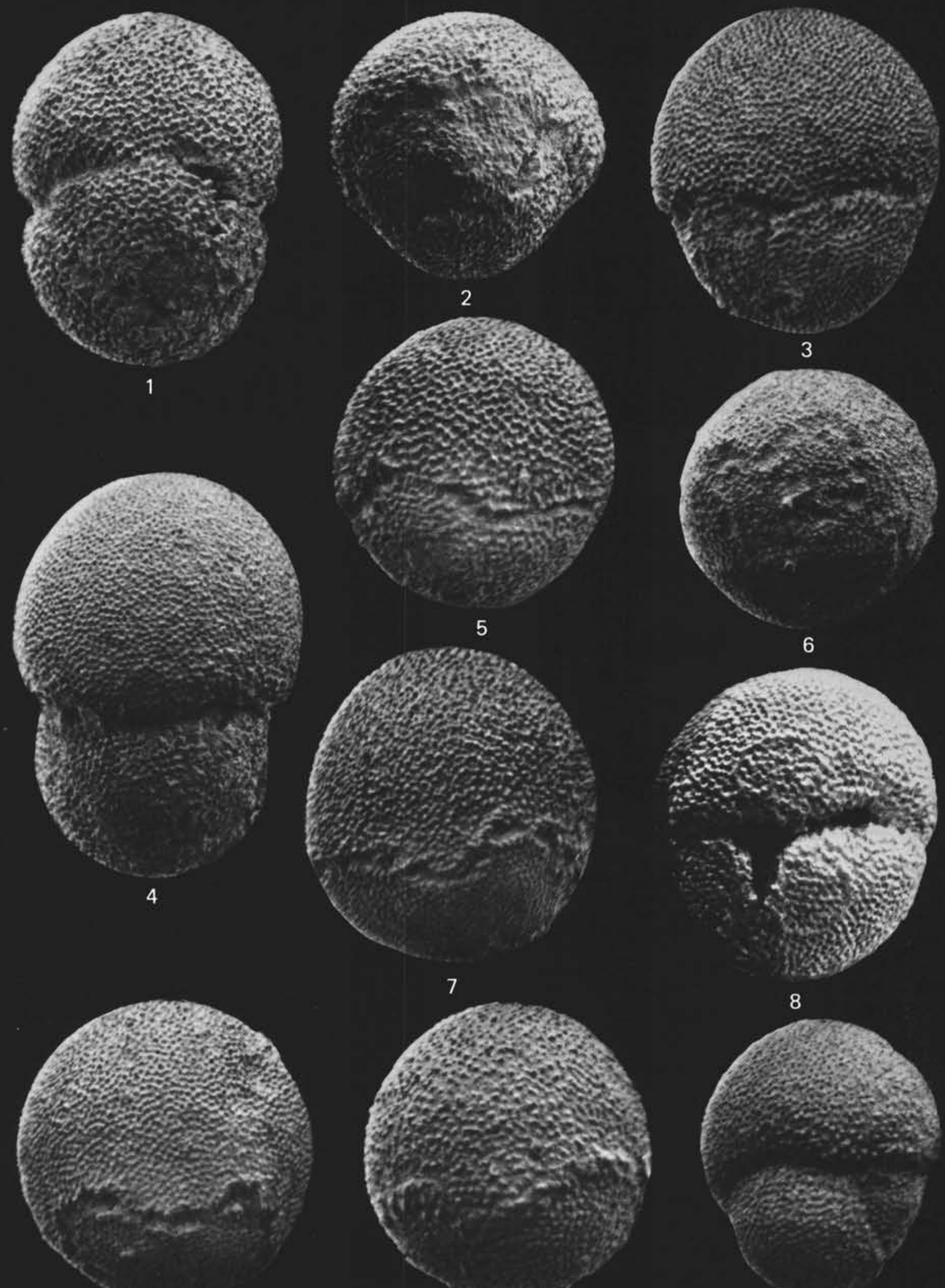


\section{PLATE 7}

Figures 1-3 Globigerinoides sicanus De Stefani.

1,2 . Umbilical views, $\times 100$. Sample 397-84-4, 10-14 cm. Zone N.8, Langhian.

3. Spiral view, $\times 100$.

Sample 397-88, CC.Zone N.8, Langhian.

Figures 4-7 Globigerinoides elongatus (d'Orbigny).

4. Spiral view, $\times 100$.

5. Spiral view, Sample 397-33-1, 50-53 cm. Zone M Pl 3, Zanclean.

6,7 . Umbilical views, $\times 100$.

Sample 397-33-3, 50-53 cm. Zone M Pl 3, Zanclean.

Figures 8, 9 Globigerinoides fragilis Borsetti and Cati.

8. Umbilical view, $\times 100$.

9. Spiral view, $\times 100$. Sample 397-49-2, 50-53 cm. Sphaeroidinellopsis seminulina paenedehiscens Zone, Tortonian.

Figures 10, 11 Globigerinoides conglobatus conglobatus (Brady).

10. Spiral view, $\times 100$.

11. Umbilical view, $\times 100$. Sample 397-34-1, 50-53 cm. Zone M Pl 3, Zanclean.

Figures 12, 13 Globigerinoides seigliei Bermudez and Bolli. Two views of the same specimen:

12. Umbilical view, $\times 100$.

13. Spiral view, $\times 100$. Sample 397-61-6, 29-31 cm. Zone N.16, Tortonian. 


\section{PLATE 7}
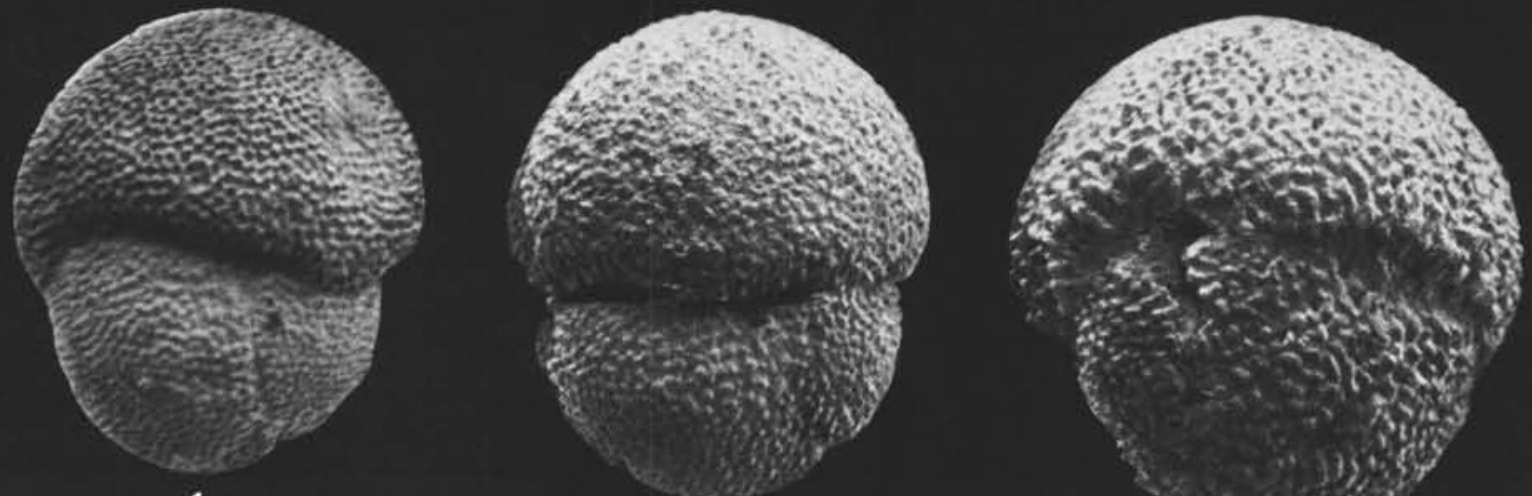

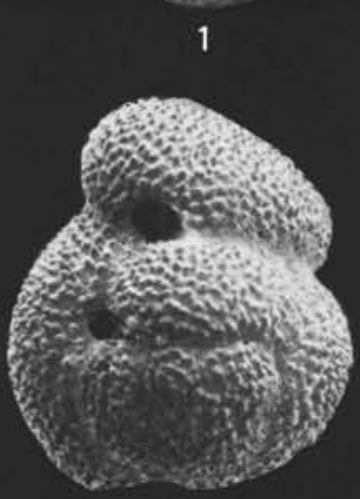

4

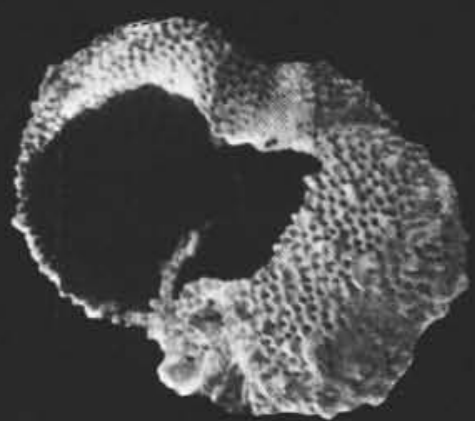

8

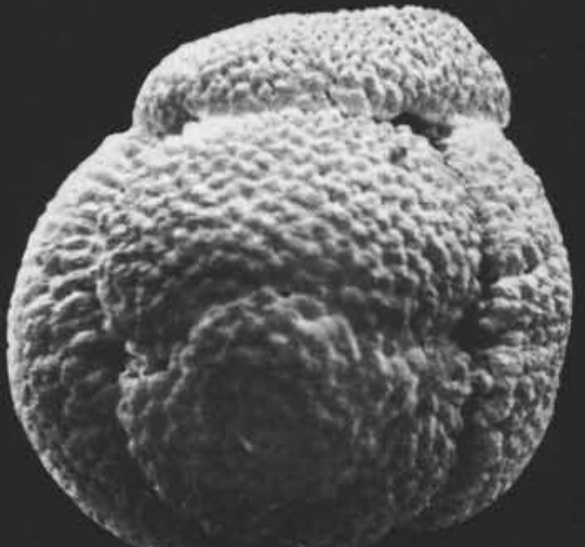

10

5
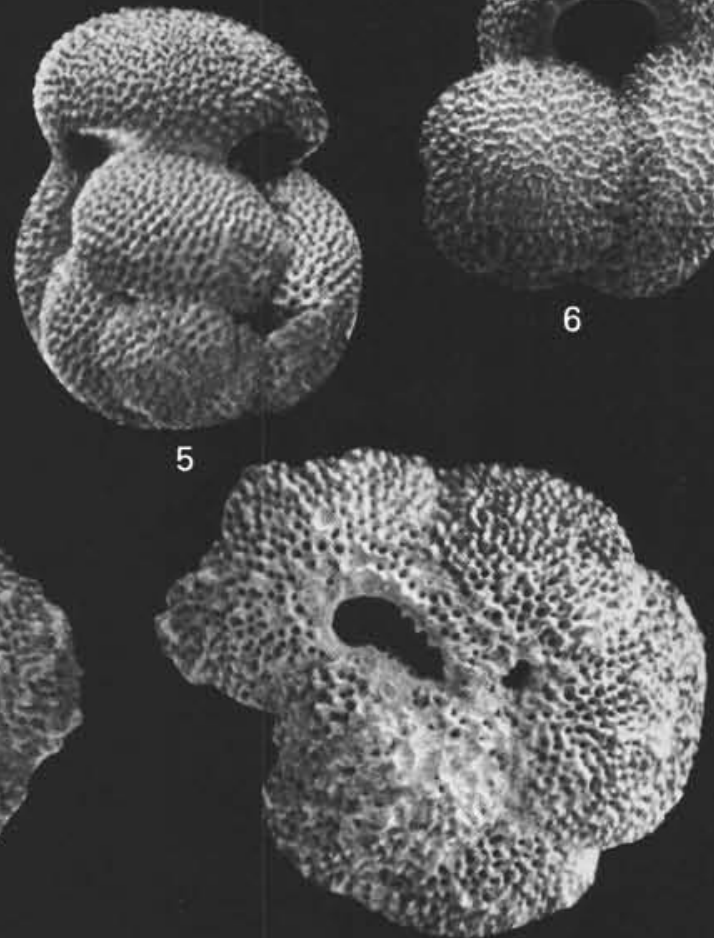

9

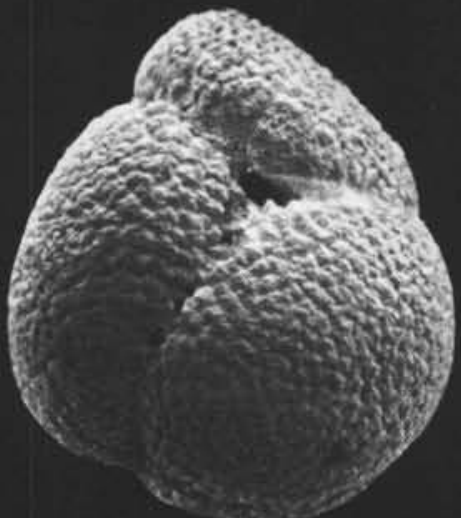

11
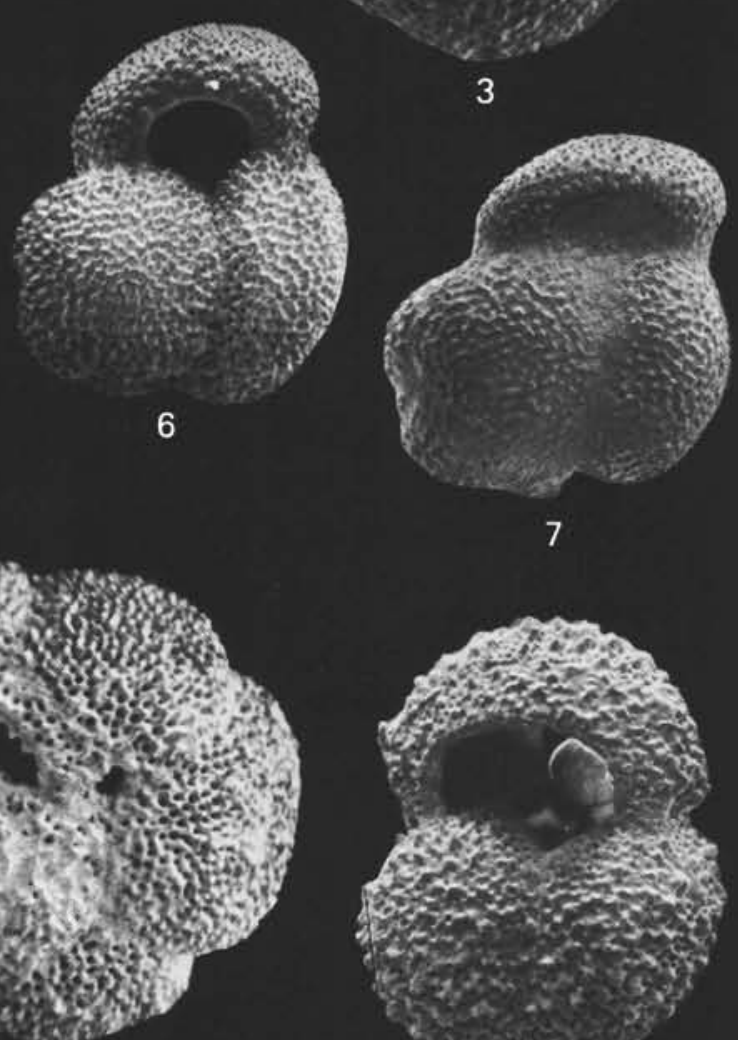

12

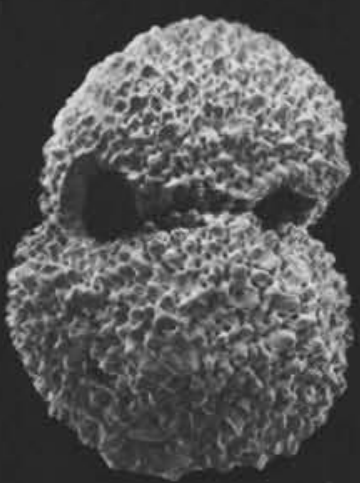

13 


\section{PLATE 8}

Figures 1, 2 Globigerinoides subquadratus Brönnimann.

1. Umbilical view, $\times 100$.

2. Spiral view, $\times 100$. Sample 397-92, CC. Zone N.7, Burdigalian.

Figure 3 Globigerinoides obliquus extremus Bolli and Bermúdez, Umbilical view, $\times 100$. Sample 397-38-5, 50-53 cm. Globigerina nepenthes Zone, Zanclean.

Figure 4 Globigerinoides obliquus obliquus Bolli.

Umbilical view, $\times 100$. Sample $397-70-3,49-52 \mathrm{~cm}$. Zone N.16, Tortonian.

Figure $5 \quad$ Globigerinoides emeisi Bolli.

Umbilical view, $\times 100$. Sample $397-34-3,50-53 \mathrm{~cm}$. Zone M Pl 3, Zanclean.

Figures 6-9 Globigerinoides quadrilobatus altiaperaturus Bolli.

6. Umbilical view, $\times 100$. Sample 397-97, CC. Zone N.7, Burdigalian.

7. Umbilical view, $\times 100$. Sample $397-94-1,2-24 \mathrm{~cm}$. Zone N.7, Burdigalian.

Two views of the same specimen:

8. Spiral view, $\times 100$.

9. Side view, $\times 100$. Sample $397-97-1,40-43 \mathrm{~cm}$. Zone N.7, Burdigalian.

Figures 10, 11 Globigerinoides bulloideus Crescenti.

10. Umbilical view, $\times 100$.

11. Spiral view, $\times 100$. Sample $397-54-6,19-21 \mathrm{~cm}$. Zone N.16, Tortonian.

Figures 12, 13 Globigerinoides bollii Blow.

12. Umbilical view, $\times 100$. Sample $397-60-2,50-53 \mathrm{~cm}$. Zone N.16, Tortonian.

13. Spiral view, $\times 100$. Sample $397-66-4,53-57 \mathrm{~cm}$. Zone N.16, Tortonian.

Figures 14, 15 Globigerinoides diminutus Bolli.

14. Umbilical view, $\times 100$. Sample 397-90, CC. Zone N.7, Burdigalian.

15. Side oblique view, $\times 100$. Sample $397-92-3,125-128 \mathrm{~cm}$. Zone N.7, Burdigalian.

Figures 16-19 Globorotalia sp.

16. Umbilical view, $\times 100$. Sample $397-60-3,106-108 \mathrm{~cm}$. Zone N.16, Tortonian.

17. Umbilical view, $\times 100$.

19. Side view, $\times 100$. Sample $397-57-4,50-52 \mathrm{~cm}$. Zone N.16, Tortonian.

18. Spiral view, $\times 100$. Sample $397-56-2,50-53 \mathrm{~cm}$. Zone N.16, Tortonian.

Figures 20-22 Globorotalia incisa Brönnimann and Resig.

Umbilical views, $\times 100$. Sample $397-34-3,50-53 \mathrm{~cm}$. Zone M Pl 3, Zanclean.

Figures 23, 24 Globorotalia clemenciae Bermúdez.

23. Umbilical view, $\times 100$. Sample $397-60-3,106-108 \mathrm{~cm}$. Slump within Zone N.16.

24. Spiral view, $\times 100$. Sample 397-86-1. 38-42 cm. Zone N.8, Langhian. 


\section{PLATE 8}
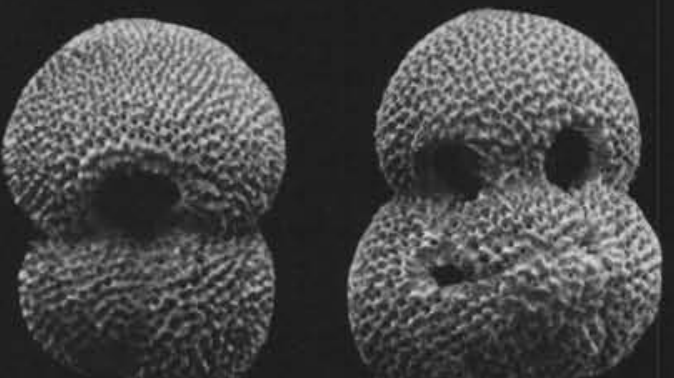

2
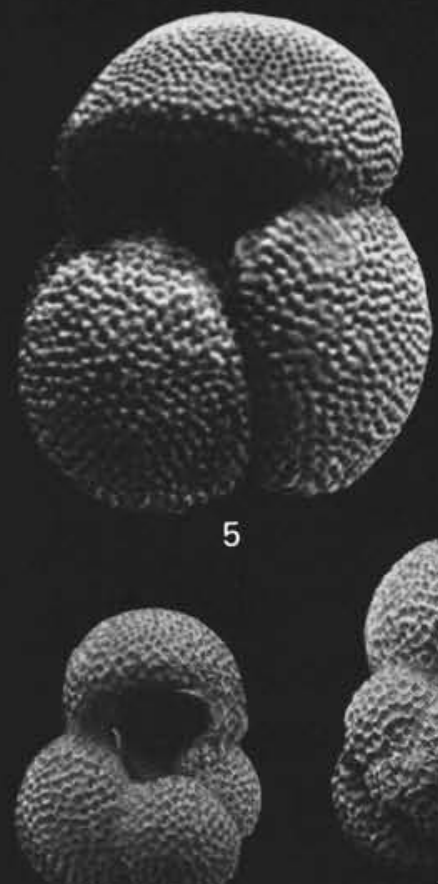

10
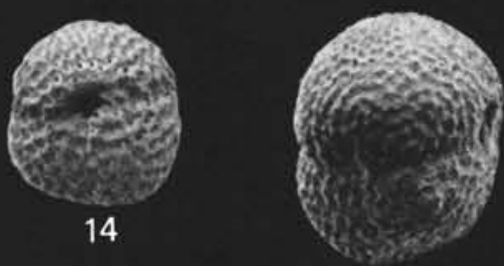

15
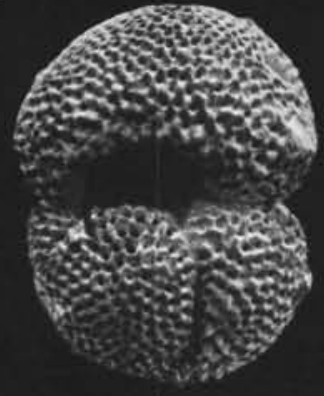

6

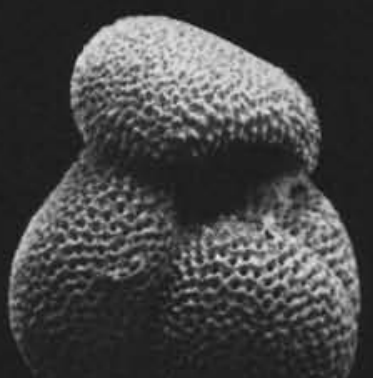

3

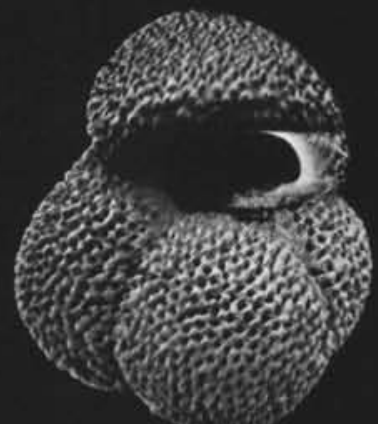

4
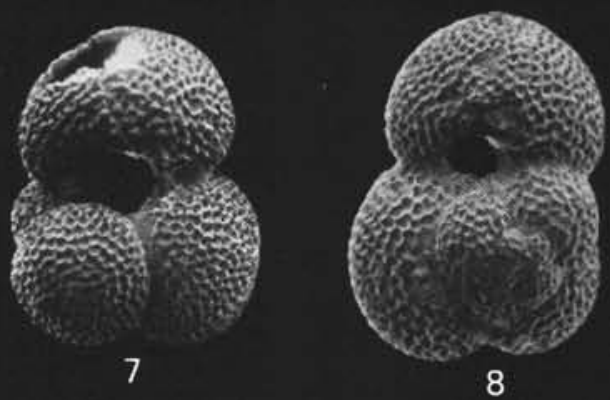

8

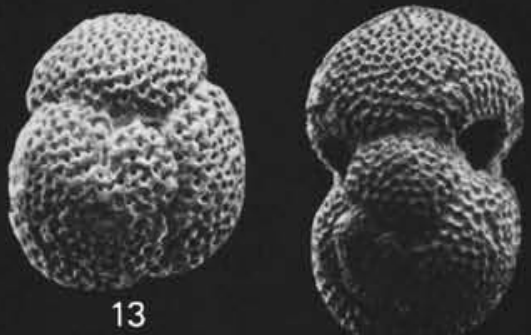

9
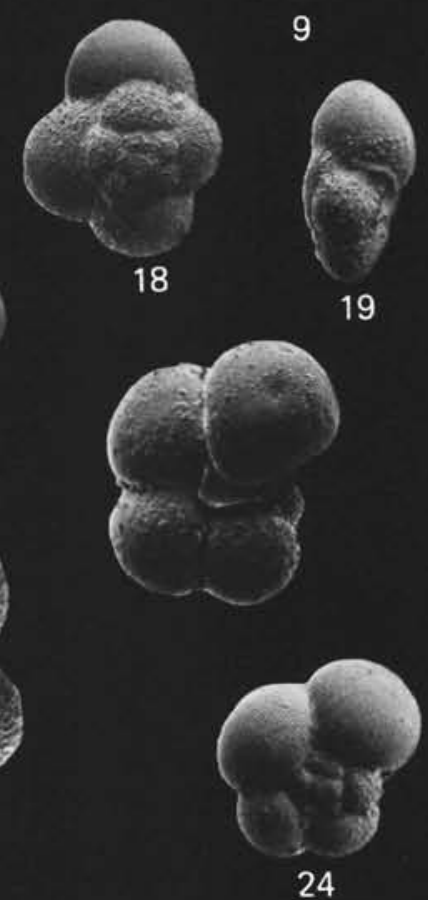


\section{PLATE 9}

Figure $1 \quad$ Globorotalia obesa Bolli.

Spiral view, $\times 100$. Sample 397-68, CC. Zone N.16, Tortonian.

Figures 2-4 Globorotalia lenguaensis Bolli.

2. Umbilical view, $\times 100$. Sample $397-58-1,40-43 \mathrm{~cm}$. Zone N.16, Tortonian.

3. Umbilical view, $\times 100$.

4. Spiral view, $\times 100$. Sample 397-63, CC. Zone N.16, Tortonian.

Figures 6-8 Globorotalia bella Jenkins.

Three views of the same specimen.

6. Umbilical view, $\times 100$.

7. Spiral view, $\times 100$.

8. Side view, $\times 100$. Sample 397-87, CC. Zone N.8. Langhian.

Figures 5, 9, Globorotalia mayeri Cushman and Ellisor.

12-14 5. Side view, $\times 100$.

9. Umbilical view, $\times 100$.

12. Spiral view, $\times 100$. Sample $397-61-5,55-57 \mathrm{~cm}$. Slump within Zone N.16.

Two views of the same specimen:

13. Umbilical view, $\times 100$.

14. Spiral view, $\times 100$. Sample $397-72$, CC. Zone N.13, Serravallian.

Figures 10, 15, Globorotalia birnageae Blow.

1610,15 . Umbilical views, $\times 100$. Sample 397-94-1, 22-24 cm. Zone N.7, Burdigalian.

16. Spiral view, $\times 100$. Sample $397-84-4,10-14 \mathrm{~cm}$. Zone N.8, Langhian.

Figures 11, 17, Globorotalia partimlabiata Ruggieri and Sprovieri.

18 11. Side view, $\times 100$.

17. Umbilical view, $\times 100$.

18. Spiral view, $\times 100$. Sample $397-58-3,38-40 \mathrm{~cm}$. Slump within Zone N.16.

Figures 19-21 Globorotalia acrostoma Wezel.

19. Umbilical view, $\times 100$. Sample 397-87, CC. Zone N.8, Langhian.

20. Umbilical view, $\times 100$. Sample $397-97-1,40-43 \mathrm{~cm}$. Zone N.7, Burdigalian.

21. Spiral view, $\times 100$. Sample 397-90, CC. Zone N.7, Burdigalian.

Figures 22-24 Globorotalia puncticulata (Deshayes).

22. Umbilical view, $\times 100$. Sample 397-34-5, 50-53 cm. Zone M Pl 3, Zanclean.

Two views of the same specimen:

23. Spiral view, $\times 100$.

24. Side view, $\times 100$. Sample 397-34-5, $50-53 \mathrm{~cm}$. Zone M Pl 3, Zanclean.

Figure 25 Globorotalia crassaformis crassaformis (Galloway and Wissler).

Umbilical view, $\times 100$. Sample 397-34-5, 50-53 cm. Zone M Pl 3, Zanclean. 


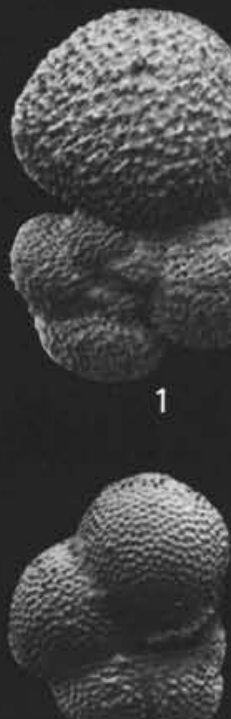

6
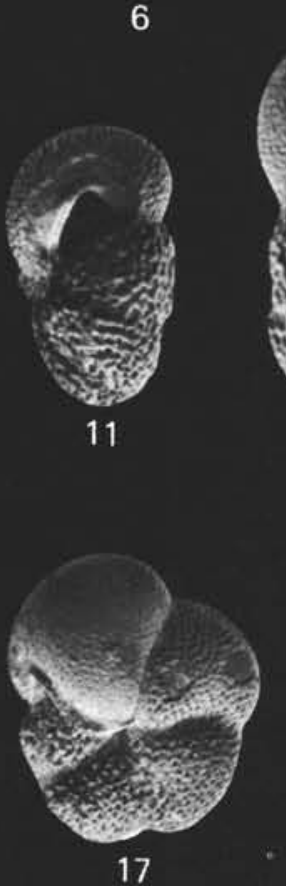

17

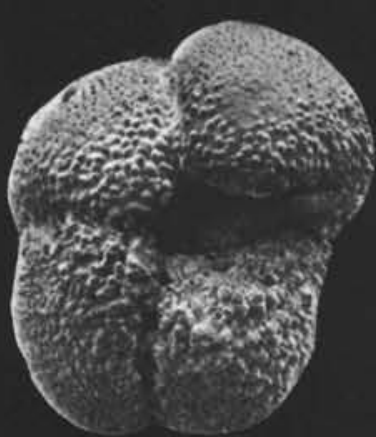

22
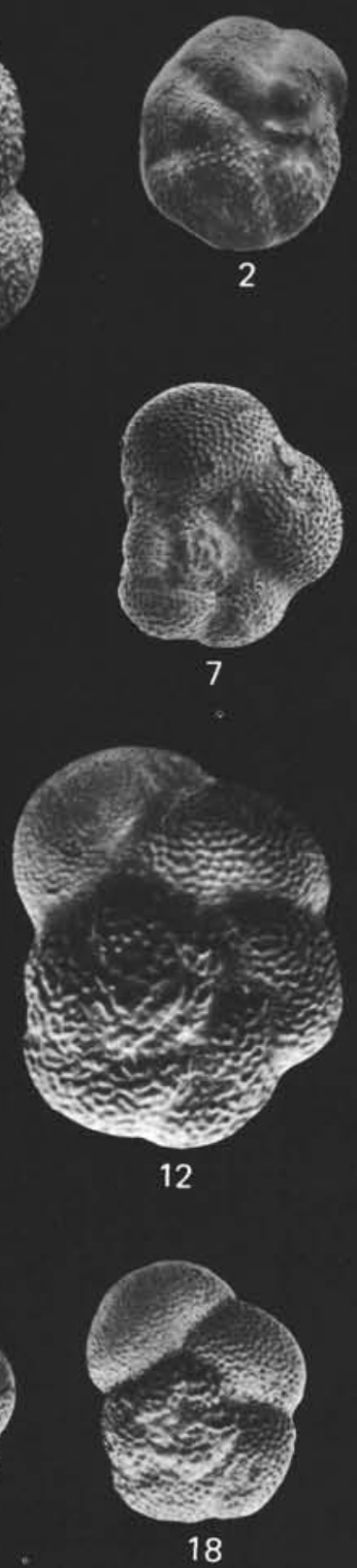

18
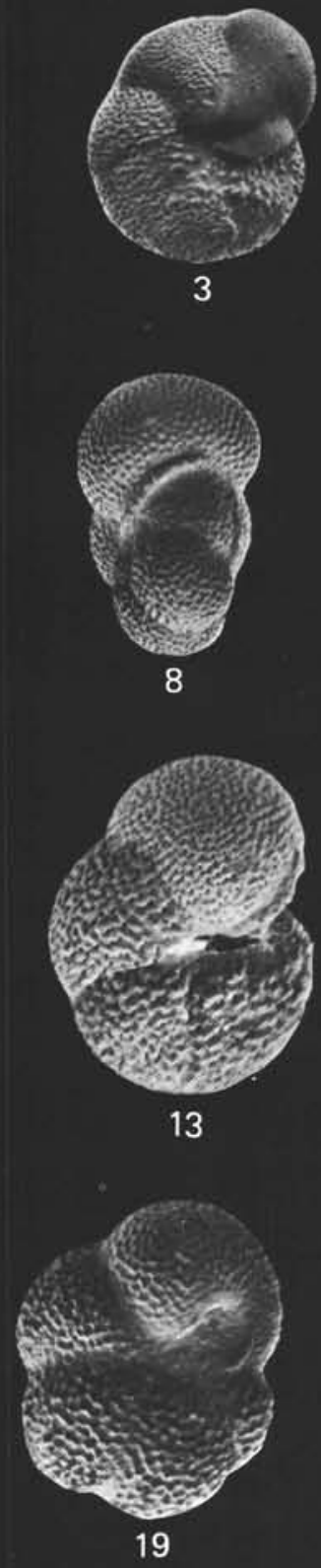
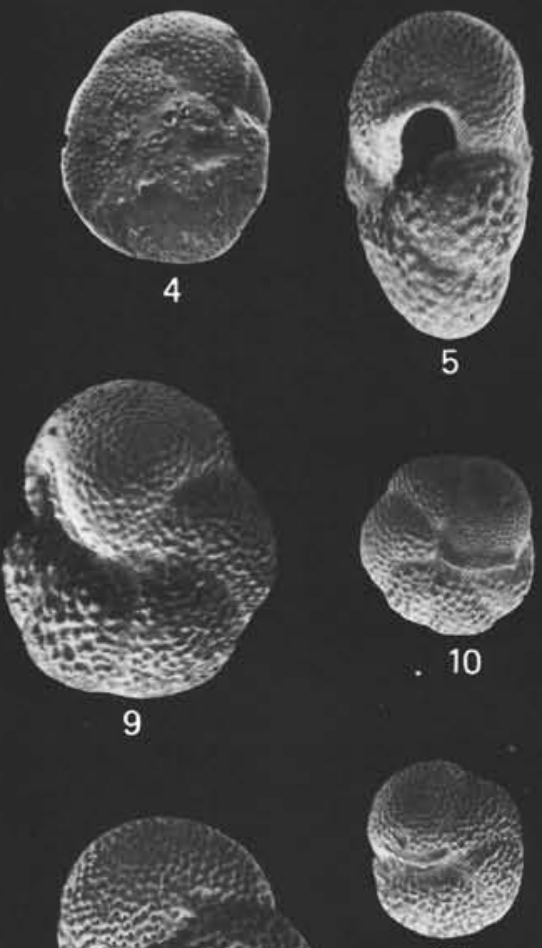

15
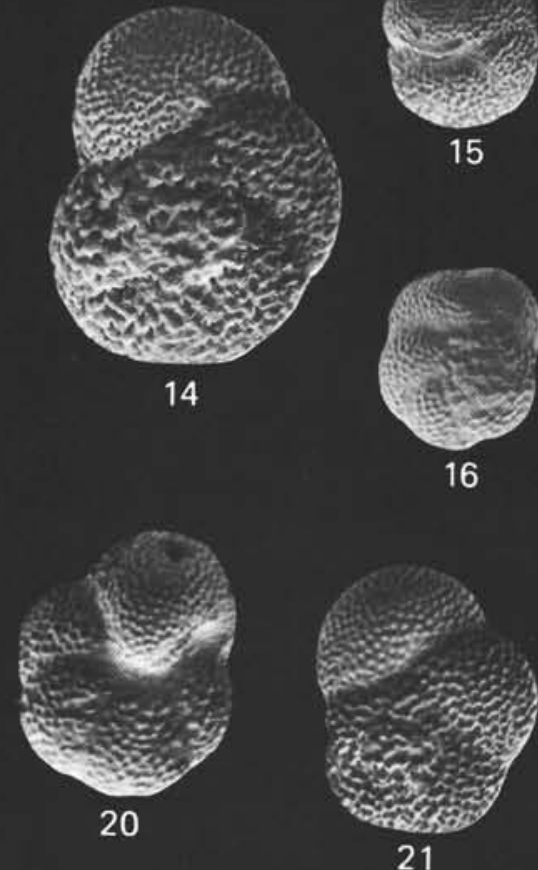
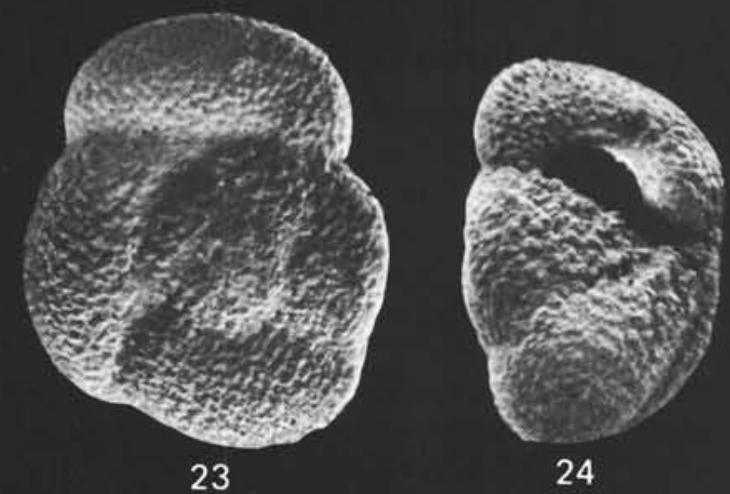

24

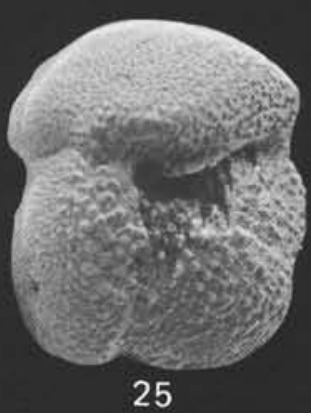




\section{PLATE 10}

Figures 1, 2 Globorotalia crassaformis crassaformis (Galloway and Wissler).

Two views of the same specimen:

1. Spiral view, $\times 100$.

2. Side view, $\times 100$. Sample 397-34-5, 50-53 cm. Zone M P1 3, Zanclean.

Figures 3, 4 Globorotalia continuosa.

3. Umbilical view, $\times 100$.

4. Side view, $\times 100$. Sample $397-69-4,50-53 \mathrm{~cm}$. Zone N.16, Tortonian.

Figures 5, 6 Globorotalia acostaensis Blow.

5. Umbilical view, $\times 100$. Sample $397-66-2,50-52 \mathrm{~cm}$. Zone N.16. Tortonian.

6. Umbilical view, $\times 100$. Sample $397-70-1,49-51 \mathrm{~cm}$. Zone N.16, Tortonian.

Figures 7, $8 \quad$ Globorotalia humerosa praehumerosa natori.

Umbilical views, $\times 100$. Sample $397-61-5,15-17 \mathrm{~cm}$. Zone N.16, Tortonian.

Figures 9, 10 Globorotalia humerosa humerosa Takayanagi and Saito.

Umbilical views, $\times 100$. Sample $397-34-4,50-53 \mathrm{~cm}$. Zone M Pl 3, Zanclean.

Figures 11-13 Globorotalia siakensis Le Roy.

11. Umbilical view, $\times 100$. Sample 397-61-4, 135-137 cm. Slump within Zone N.16.

12. Umbilical view of a reworked specimen, $\times 100$. Sample 397-69-2, $56-59 \mathrm{~cm}$. Zone N.16, Tortonian.

13. Umbilical view, $\times 100$. Sample $397-72-1,51-53 \mathrm{~cm}$. Zone N.14, Serravallian.

Figures 14, 15 Globorotalia mineacea Bermúdez and Bolli.

14. Umbilical view, $\times 100$.

15. Spiral view, $\times 100$. Sample $397-43-2,40-43 \mathrm{~cm}$. Globigerina nepenthes Zone, Messinian.

Figures 16-18 Negloboquadrina dutertrei s.1.

16,17 . Umbilical views, $\times 100$. Sample $397-41-3,50-53 \mathrm{~cm}$. Globigerina nepenthes Zone, Zanclean.

18. Umbilical view, $\times 100$. Sample $397-34-6,40-43 \mathrm{~cm}$. Zone M Pl 3, Zanclean.

Figure 19 Globorotalia scitula (Brady).

Umbilical view, $\times 100$. Sample 397-39-2, 50-52 cm. Globigerina nepenthes Zone, Zanclean.

Figures 20, 21 Globorotalia margaritae margaritae Bolli and Bermúdez.

20. Umbilical view, $\times 100$. Sample $397-37-3,51-53 \mathrm{~cm}$. Globigerina nepenthes Zone, Zanclean.

21. Spiral view, $\times 100$. Sample 397-35 CC. Zone M Pl 3, Zanclean. 


\section{PLATE 10}
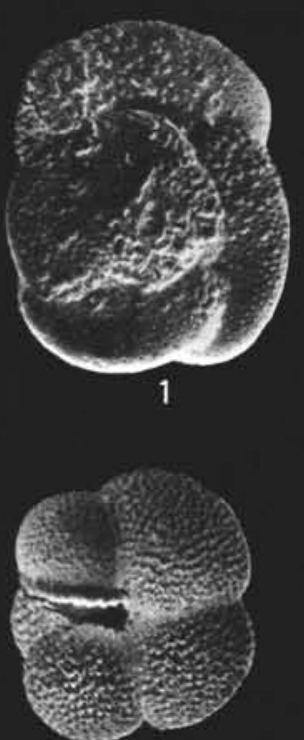

6

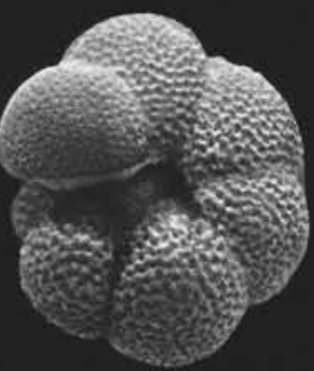

10
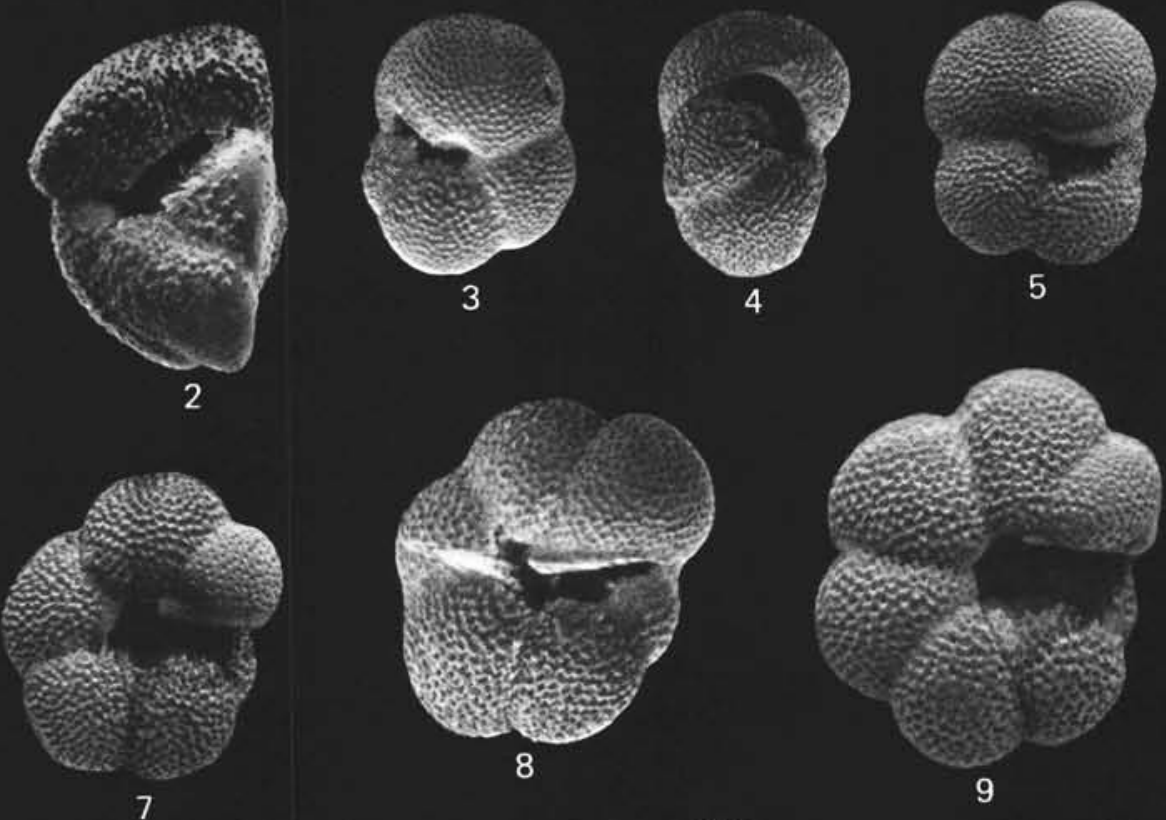

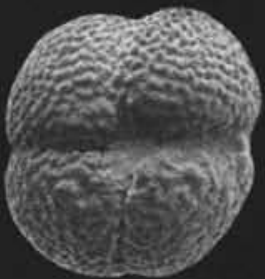

14

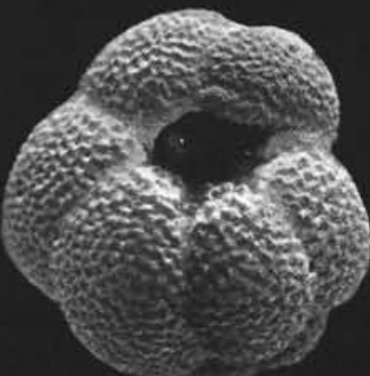

18

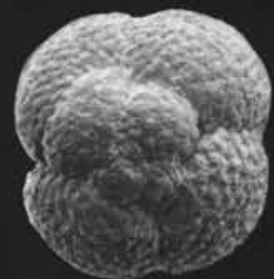

15

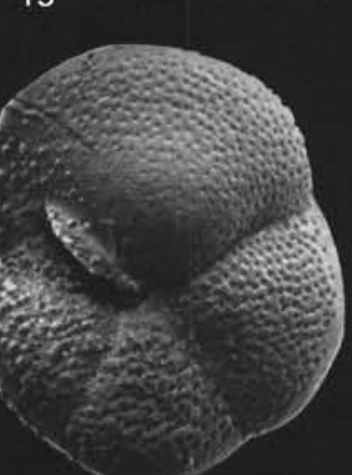

19
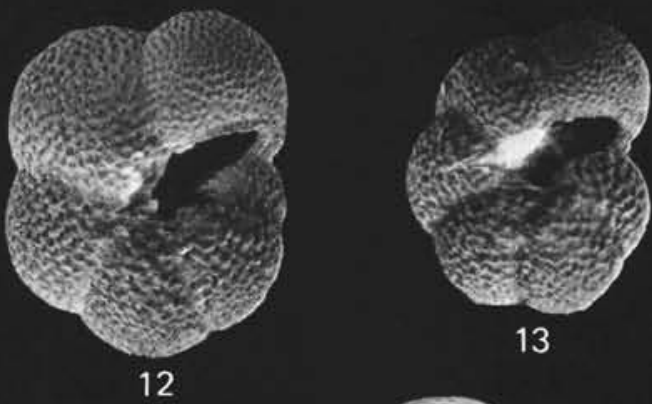

11

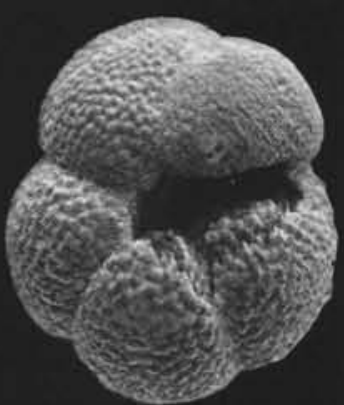

16
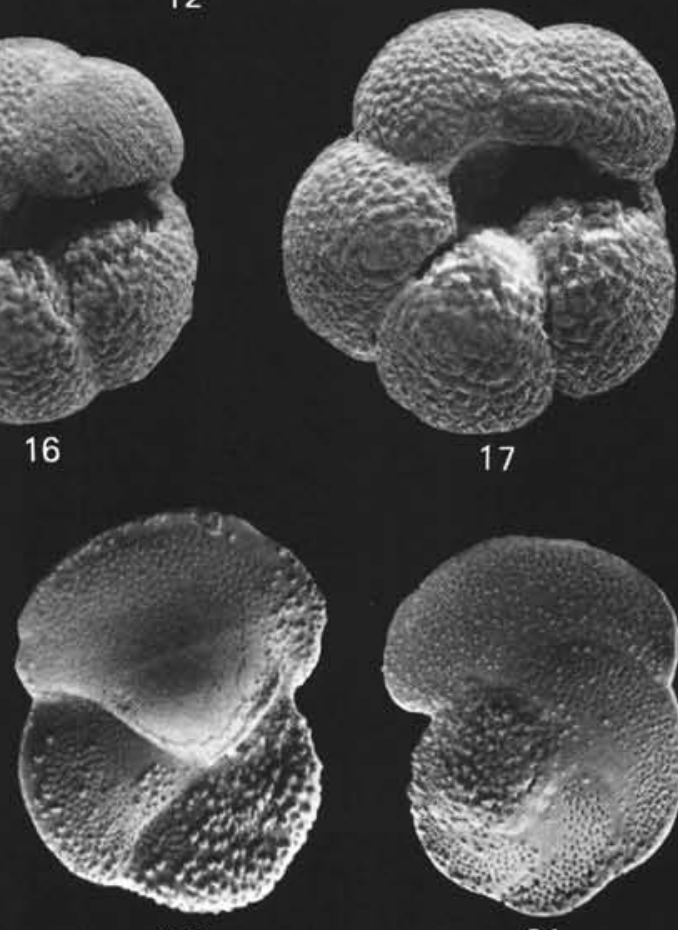

20

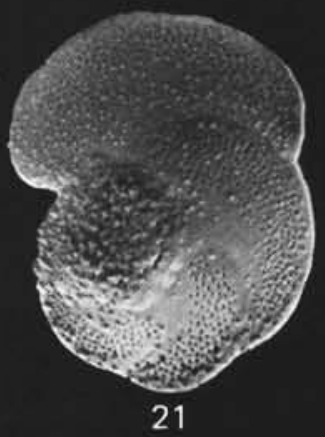




\section{PLATE 11}

Figures 1-3 Globorotalia peripheroronda Blow and Banner.

1. Umbilical view, $\times 100$.

2. Spiral view, $\times 100$. Sample $397-85$, CC. Zone N.8, Langhian.

3. Side view, $\times 100$. Sample 397-90, CC. Zone N.7, Burdigalian.

Figures 4-6, 10 Globorotalia peripheroacuta Blow and Banner.

4. Umbilical view, $\times 100$.

5. Side view, $\times 100$. Sample $397-77-3,44-46 \mathrm{~cm}$. Zone N.11 (N.10?), Serravallian.

Two views of the same specimen:

6. Side view, $\times 100$.

10. Spiral view, $\times 100$. Sample $397-76-3,43-45 \mathrm{~cm}$. Zone N.11, Serravallian.

Figures 7-9 Globoratalia praefohsi Blow and Banner.

7. Side view, $\times 100$. Sample 397-76, CC. Zone N.11, Serravallian.

Two views of the same specimen:

8. Umbilical view, $\times 100$.

9. Side view, $\times 100$. Sample 397-76, CC. Zone N.11, Serravallian.

Figures 11-16, Globorotalia fohsi s.l.

Two views of the same specimen:

11. Umbilical view, $\times 100$.

12. Side view, $\times 100$. Sample $397-73-1,138-140 \mathrm{~cm}$. Zone N.13, Serravallian.

Two views of the same specimen:

13. Spiral view, $\times 100$.

14. Side views, $\times 100$. Sample $397-73-1,138-140 \mathrm{~cm}$. Zone N.13, Serravallian.

Two views of the same specimen:

15. Side view, $\times 100$.

16. Umbilical view, $\times 100$. Sample $397-74-1,50-52 \mathrm{~cm}$. Zone N.13, Serravallian.

19. Spiral view, $\times 100$. Sample $397-74-1,50-52 \mathrm{~cm}$. Zone N.13, Serravallian.

Figures 17, 18 Globorotalia praefohsi Blow and Banner.

Two views of the same specimen:

17. Umbilical view, $\times 100$.

18. Spiral view, $\times 100$.

Sample 397-58-3, 38-40 cm. Slump within Zone N.16. 


\section{PLATE 11}
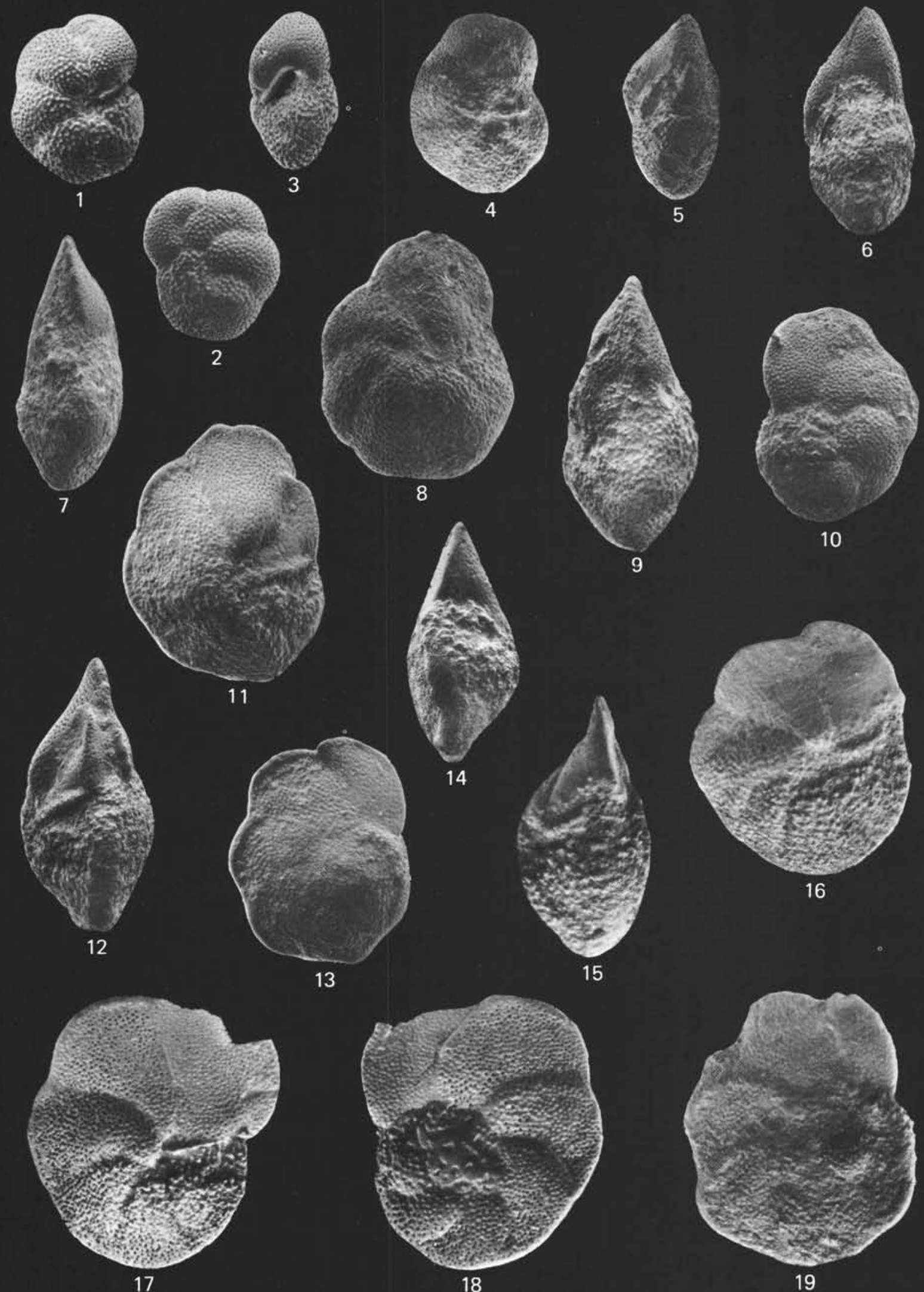

13

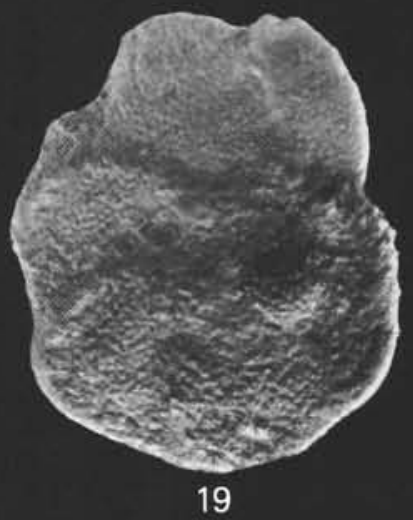




\section{PLATE 12}

Figures 1, 2, 5

Figures $3,4,9$

Figures 6-8

Figures 10-14, 19

Figures 15-17

Figure 18
Globorotalia fohsi.

1. Spiral view of the specimens in Figures 11 and 12 of Plate 11, $\times 100$. Sample 397-73-1, $138-140 \mathrm{~cm}$. Zone N.13, Serravallian.

2. Spiral view, $\times 100$.

5. Spiral view, $\times 100$. Sample $397-58-3,38-40 \mathrm{~cm}$. Slump within Zone N.16.

Globorotalia miotumida Jenkins.

3. Umbilical view, $\times 100$.

9. Spiral view, $\times 100$. Sample 397-48-3, 26-28 cm. Sphaeroidinellopsis seminulina paenedehiscens Zone, Messinian.

4. Side view, $\times 100$. Sample $397-47-2,50-52 \mathrm{~cm}$. Sphaeroidinellopsis seminulina paenedehiscens Zone, Messinian.

Globorotalia aff. ungulata Bermúdez.

Three views of the same specimen:

6. Umbilical view, $\times 100$.

7. Side view, $\times 100$.

8. Spiral view, $\times 100$. Sample $397-34-3,50-53 \mathrm{~cm}$. Zone M Pl 3, Zanclean.

Globorotalia tumida plesiotumida Blow and Banner.

Three views of the same specimen:

10. Umbilical view, $\times 100$.

14. Spiral view, $\times 100$.

19. Side view, $\times 100$. Sample $397-47-4,50-52 \mathrm{~cm}$. Sphaeroidinellopsis seminulina paenedehiscens Zone, Messinian.

Two views of the same specimen:

11. Umbilical view, $\times 100$.

13. Side view, $\times 100$. Sample $397-43-6,40-43 \mathrm{~cm}$. Globigerina nepenthes Zone, Messinian.

12. Spiral view, $\times 100$. Sample $397-43-6,40-43 \mathrm{~cm}$. Globigerina nepenthes Zone, Messinian.

Globorotalia merotumida Blow and Banner.

Three views of the same specimen:

15. Umbilical view, $\times 100$.

16. Spiral view, $\times 100$.

17. Side view, $\times 100$. Sample $397-67-2,50-52 \mathrm{~cm}$. Zone N.16, Tortonian.

Globorotalia cf. miozea miozea Finlay.

Spiral view, $\times 100$. Sample $397-85-4,126-128 \mathrm{~cm}$. Zone N.8, Langhian. 

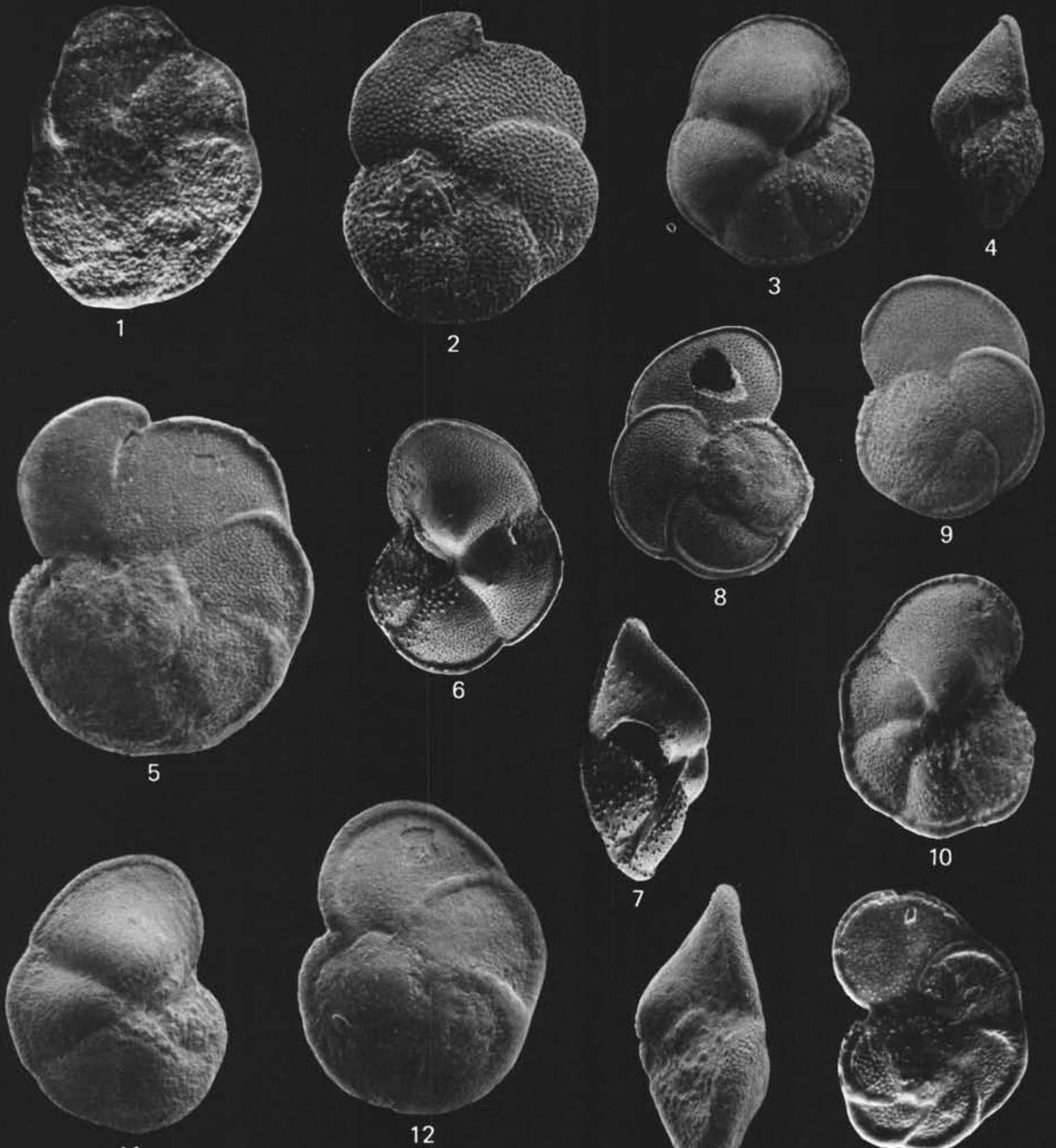

11
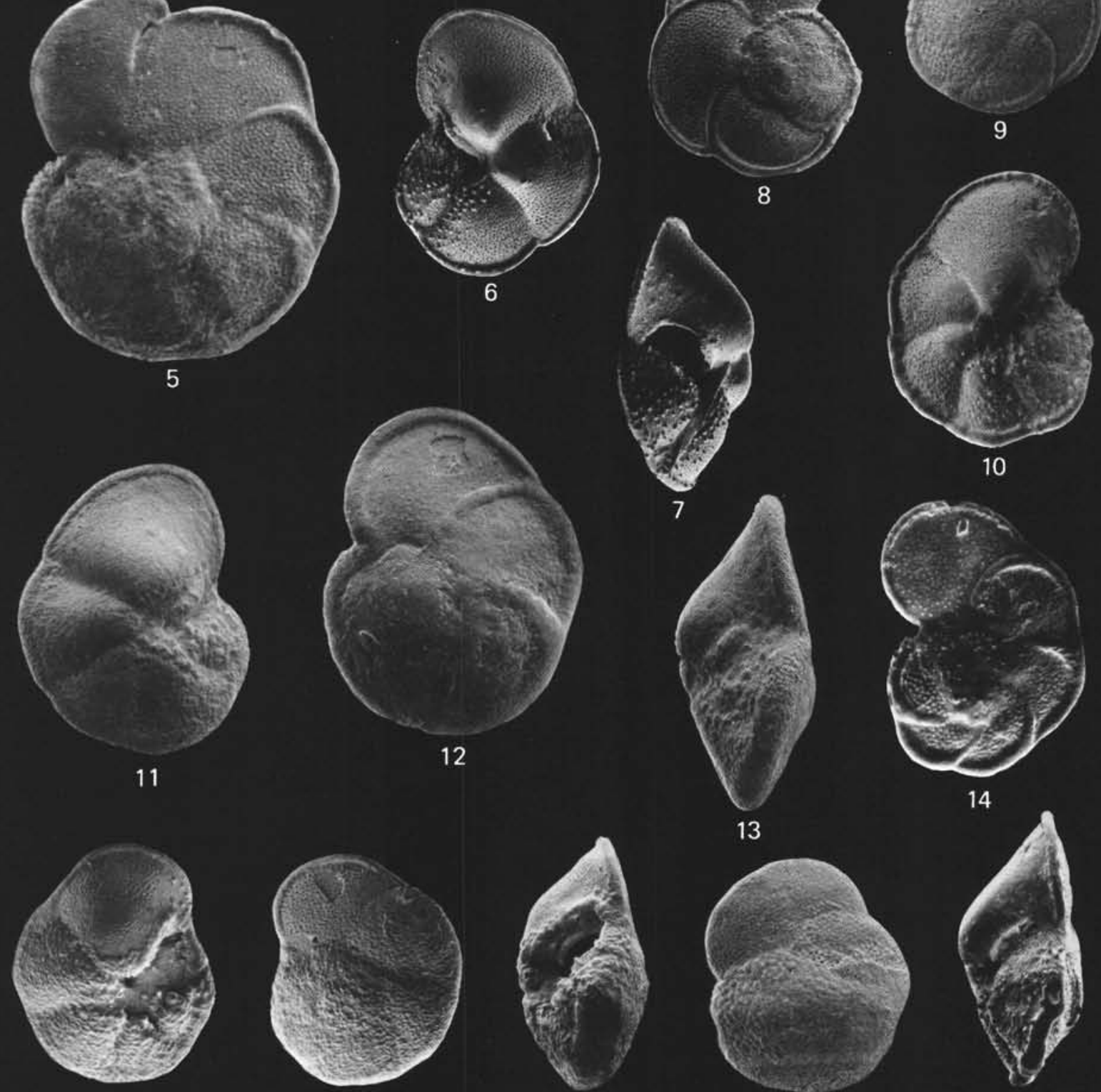

15
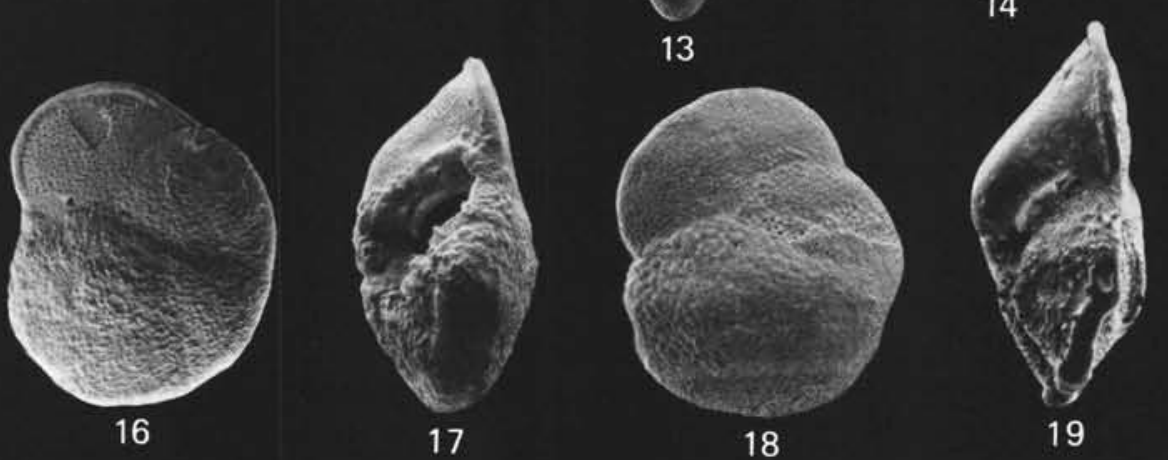


\section{PLATE 13}

Figure 1

Figures 2-4

Figures 5-8

Figures 9-13

Figures 14-21
Globorotalia cf. miozea miozea Finlay.

Umbilical view, $\times 100$.

Sample 397-93-3, 3-5 cm. Zone N.7, Burdigalian.

Globorotalia miozea miozea Finlay.

2. Umbilical view, $\times 100$.

3. Spiral view, $\times 100$.

4. Side view, $\times 100$.

Sample 397-77-2, 60-63 cm. Zone N.11 (N.10?), Serravallian.

Globorotalia praescitula Blow.

5. Umbilical view, $\times 100$.

Sample 397-86-1, 38-42 cm. Zone N.8, Langhian.

Three views of the same specimen:

6. Umbilical view, $\times 100$.

7. Spiral view, $\times 100$.

8. Side view, $\times 100$.

Sample 397-86-1, 38-42 cm. Zone N.8, Langhian.

Globorotalia praemenardii archeomenardii Bolli.

9. Umbilical view, $\times 100$.

10. Side view, $\times 100$.

Sample 397-80-2, 52-54 cm. Zone N.8, Langhian.

11. Spiral view, $\times 100$.

Sample 397-78, CC. Zone N.8, Langhian.

Two views of the same specimen:

12. Spiral view, $\times 100$.

13. Side view, $\times 100$.

Sample 397-78, CC. Zone N.8, Langhian.

Globorotalia praemenardii praemenardii Cushman and Stainforth.

14. Spiral view, $\times 100$.

Sample 397-75, CC. Zone N.12, Serravallian.

Three views of the same specimen:

15. Umbilical view, $\times 100$.

16. Spiral view, $\times 100$.

17. Side view, $\times 100$.

Sample 397-74-2, 68-70 cm. Zone N.12, Serravallian.

18. Spiral view, $\times 100$.

Sample 397-76-3, $43-45 \mathrm{~cm}$. Zone N. 11, Serravallian.

Three views of the same specimen:

19. Umbilical view, $\times 100$.

20. Side view, $\times 100$.

21. Spiral view, $\times 100$.

Sample 397-76-1, 95-97 cm. Zone N.11, Serravallian. 
PLATE 13

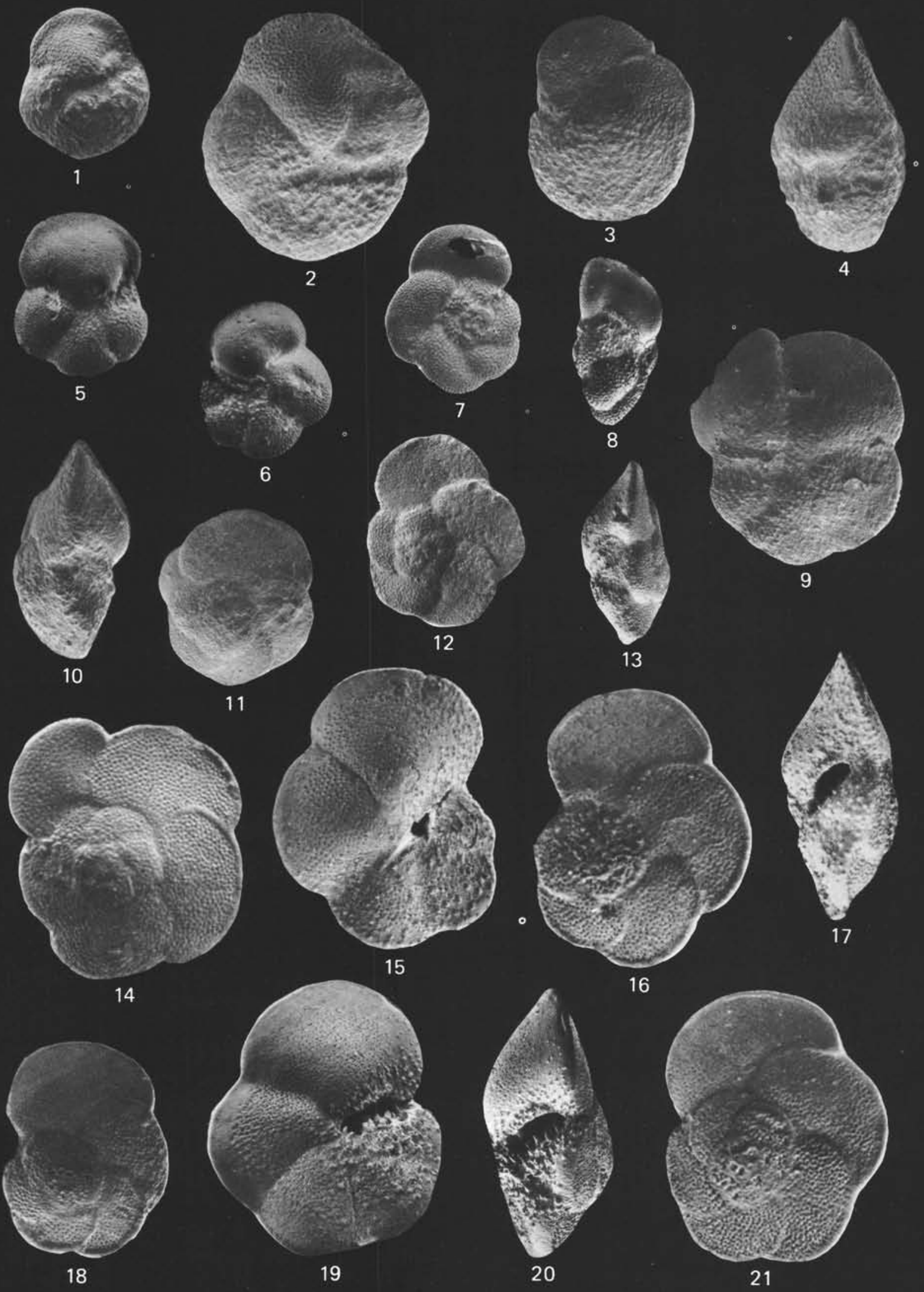




\section{PLATE 14}

Figure 1

Figures 5, 7, 8
Globorotalia praemenardii praemenardii Cushman and Stainforth.

Spiral view, $\times 100$.

Sample 397-77, CC. Zone N.11 (N.10?), Serravallian.

Globorotalia cultrata s.1.

Three views of the same specimen:

2. Spiral view, $\times 100$.

3. Side view, $\times 100$.

6. Umbilical view, $\times 100$.

Sample 397-67-1, 49-52 cm. Zone N.16, Tortonian.

4. Spiral view, $\times 50$. Sample 397-61-2, 60-63 cm. Zone N. 16, Tortonian.

Globorotalia multicamerata Cushman and Jarvis.

5. Spiral view, $\times 100$.

8. Umbilical view, $\times 100$.

Sample 397-34-1, 50-53 cm. Zone M Pl 3, Zanclean.

7. Spiral view, $\times 100$.

Sample 397-38-5, 50-53 cm. Globigerina nepenthes Zone, Zanclean. 


\section{PLATE 14}
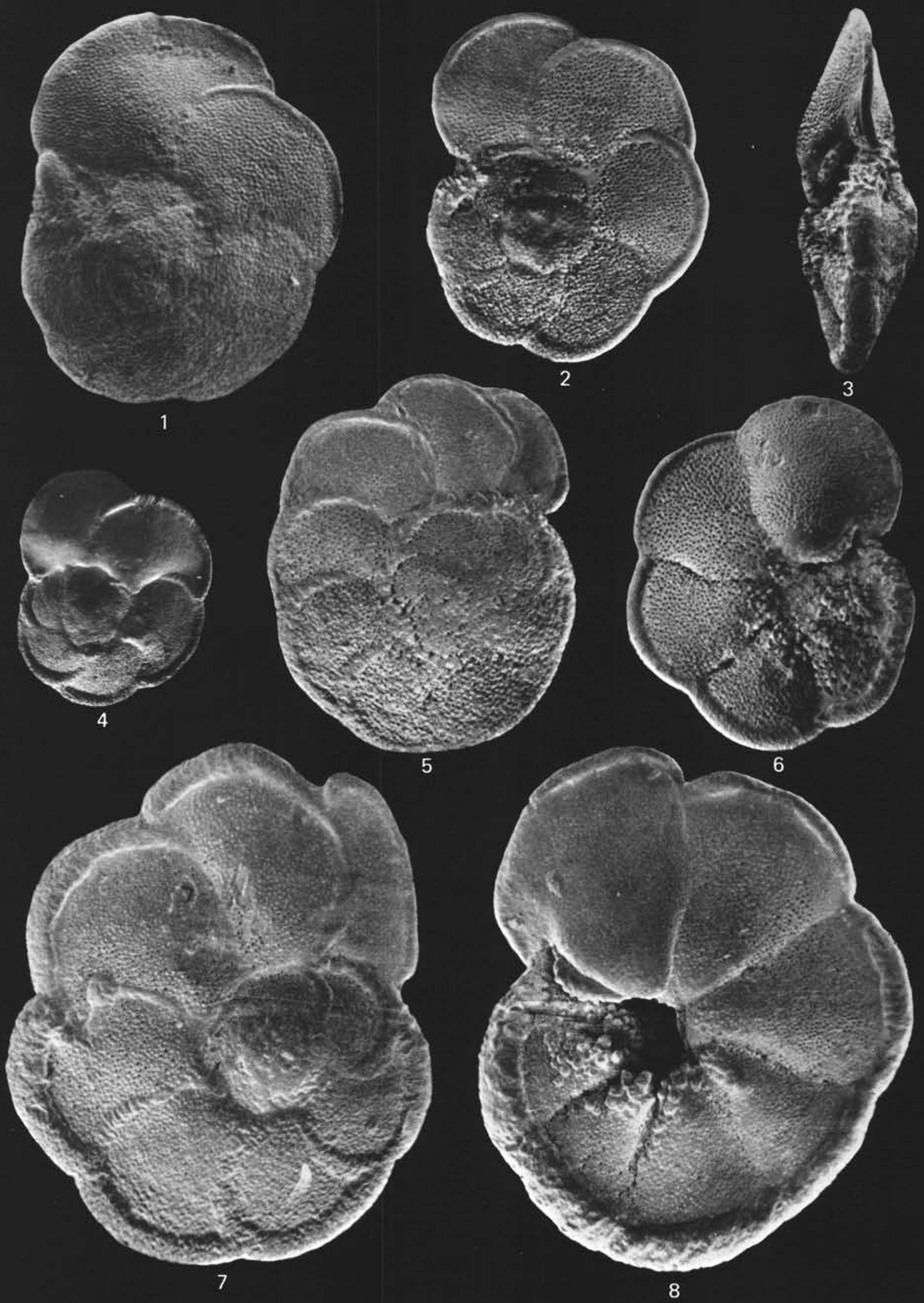